
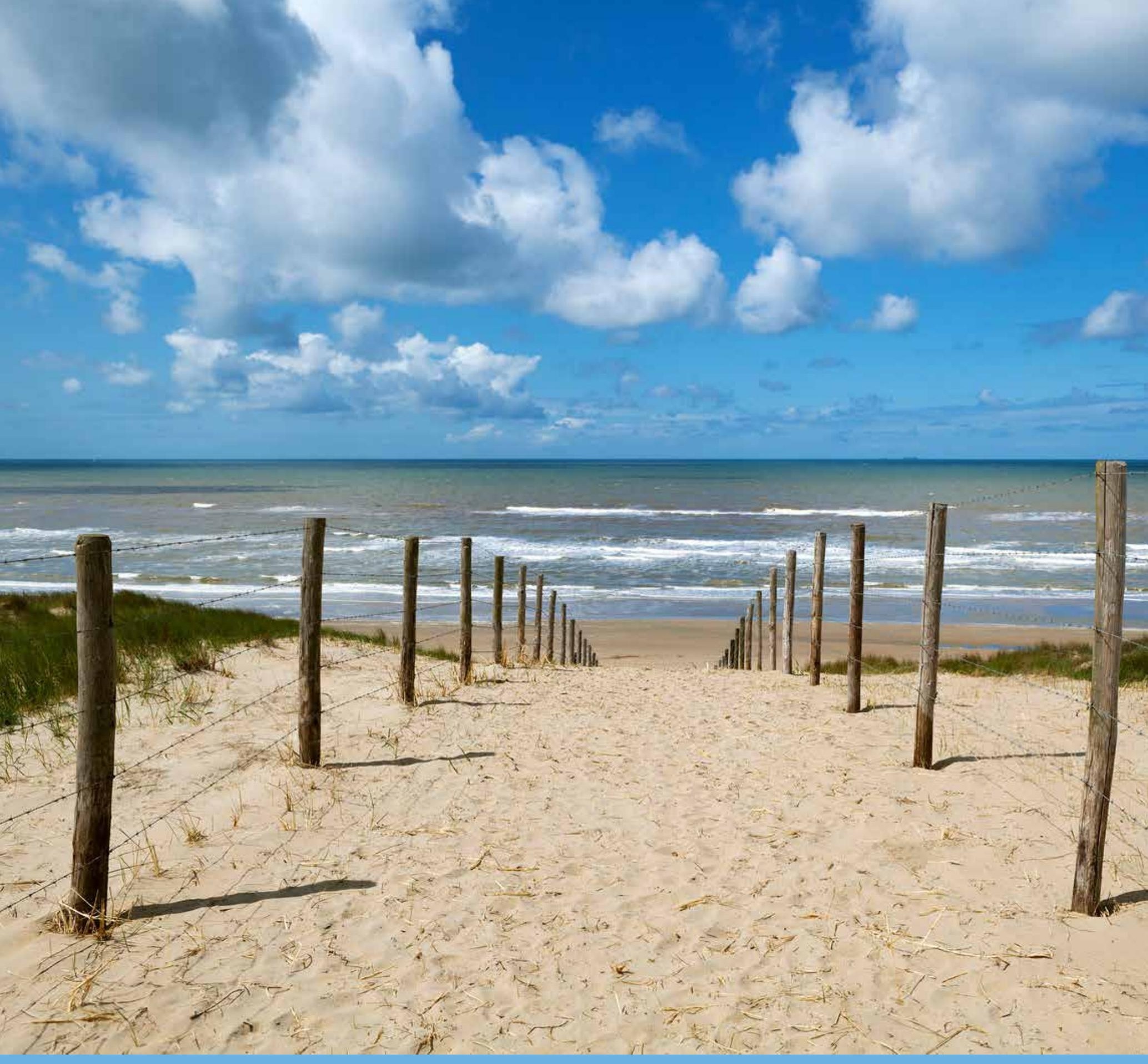

\title{
Kansen van de Noordzee voor de Provincie Zuid-Holland
}

Roebeling, P.C., S. van den Burg, O. van der Valk, T. Selnes, A. Verkennis, M. Briene, A. van Langevelde, H. Schutte, H. van Kempen, E. Vrensen, A.M. van Rij \& S. Rijswijk 



\section{Kansen van de Noordzee voor de Provincie Zuid-Holland}

1: Roebeling, P.C., S. van den Burg, O. van der Valk en T. Selnes

2: Verkennis, A., M. Briene, A. van Langevelde en H. Schutte

3: Kempen, H. van., E. Vrensen, A.M. van Rij en S. Rijswijk

1 Wageningen Economic Research

2 ECORYS

3 LOS StadOmLand

Dit onderzoek, onderdeel van het programma Kennis Zuid-Holland/ToekomstAgenda, is uitgevoerd door Wageningen Economic Research in samenwerking met ECORYS en LOS StadOmLand, in opdracht van en gefinancierd door de Provincie Zuid-Holland.

Wageningen Economic Research

Wageningen, juli 2021 
Roebeling, P.C., S. van den Burg, O. van der Valk, T. Selnes, A. Verkennis, M. Briene, H. Schutte, A. van Langevelde, H. van Kempen, E. Vrensen, A.M. van Rij \& S. Rijswijk, 2021. Kansen van de Noordzee voor de Provincie Zuid-Holland. Wageningen, Wageningen Economic Research, Rapport 2021-088. 86 blz.; 31 fig.; 11 tab.; 32 ref.

De ontwikkelingen op de Noordzee bieden kansen om de economie in de Provincie Zuid-Holland te versterken en de ruimtelijke omgevingskwaliteit te verbeteren. Met dit onderzoek krijgt de Provincie Zuid-Holland een beter inzicht in de ontwikkelingen op en rond de Noordzee die de provinciale ambities kunnen beïnvloeden en vormen. Op basis van verwachte trends en ontwikkelingen op en rond de Noordzee en gerelateerde visies, ambities en kansen van stakeholders ontwikkelen we, uitgaande van de Noordzeescenario's ontwikkeld door PBL (2018, 2019), vier scenario's voor de toekomst voor de Provincie Zuid-Holland. Voor ieder van deze scenario's geven wij inzicht in de verwachte economische en ruimtelijke impacts evenals een overzicht van de maatschappelijke opgaven, de mogelijke beleidsinstrumenten en de gerelateerde rollen \& verantwoordelijkheden die deze scenario's met zich meebrengen. Deze scenario's vormen de basis voor de definitie van no-regret beleidsaanbevelingen rond ontwikkelingen en kansen gerelateerd aan activiteiten op zee, aan de kust en in de haven. Hiermee agenderen wij onderwerpen voor het ontwikkelen van een samenhangend (toekomstig) economische en ruimtelijke omgevingsbeleid van de Provincie Zuid-Holland.

The developments on the North Sea offer opportunities to strengthen the economy of the Province of South Holland and to improve the spatial quality of the environment. With this research, the Province of South Holland gains better insight into the developments on and surrounding the North Sea that can influence and shape the provincial ambitions. Based on expected trends and developments on and surrounding the North Sea and related stakeholders' visions, ambitions and opportunities, we develop four scenarios for the future of the Province of South Holland, building on the North Sea scenarios developed by PBL $(2018,2019)$. For each of these scenarios, we provide insight into the expected economic and spatial impacts as well as an overview of the social challenges, the possible policy instruments and the related roles $\&$ responsibilities that these scenarios entail. These scenarios form the basis for the definition of no-regret policy recommendations regarding developments and opportunities related to activities on sea, on the coast and in the port. With this we put topics on the agenda for the development of a coherent (future) economic and spatial-environmental policy for the Province of South Holland.

Trefwoorden: Noordzee, Provincie, stakeholders, toekomstscenario's, economie, ruimte \& omgeving, beleid \& bestuur

Dit rapport is gratis te downloaden op https://doi.org/10.18174/549956 of op www.wur. nl/economicresearch (onder Wageningen Economic Research publicaties).

(C) 2021 Wageningen Economic Research

Postbus 29703, 2502 LS Den Haag, T 07033583 30, E communications.ssg@wur.nl, www. wur.nl/economic-research. Wageningen Economic Research is onderdeel van Wageningen University \& Research.

\section{(cc) BY-NC}

Dit werk valt onder een Creative Commons Naamsvermelding-Niet Commercieel 4.0 Internationaallicentie.

(C) Wageningen Economic Research, onderdeel van Stichting Wageningen Research, 2021 De gebruiker mag het werk kopiëren, verspreiden en doorgeven en afgeleide werken maken. Materiaal van derden waarvan in het werk gebruik is gemaakt en waarop intellectuele eigendomsrechten berusten, mogen niet zonder voorafgaande toestemming van derden gebruikt worden. De gebruiker dient bij het werk de door de maker of de licentiegever aangegeven naam te vermelden, maar niet zodanig dat de indruk gewekt wordt dat zij daarmee instemmen met het werk van de gebruiker of het gebruik van het werk. De gebruiker mag het werk niet voor commerciële doeleinden gebruiken.

Wageningen Economic Research aanvaardt geen aansprakelijkheid voor eventuele schade voortvloeiend uit het gebruik van de resultaten van dit onderzoek of de toepassing van de adviezen.

Wageningen Economic Research is ISO 9001:2015 gecertificeerd.

Wageningen Economic Research Rapport 2021-088 | Projectcode 2282700563

Foto omslag: Shutterstock 


\section{Inhoud}

Woord vooraf $\quad 5$

Samenvatting $\quad 6$

$\begin{array}{lll}\text { S.1 Kernvraag } & 6\end{array}$

S.2 Boodschap $\quad 6$

$\begin{array}{lll}\text { S.3 Methodologie } & 7\end{array}$

$\begin{array}{ll}\text { Summary } & 8\end{array}$

S.1 Key question $\quad 8$

S.2 Message $\quad 8$

$\begin{array}{ll}\text { S.3 Method } & 9\end{array}$

1

$\begin{array}{lr}\text { Introductie } & 10\end{array}$

$\begin{array}{lll}1.1 & \text { Aanleiding } & 10\end{array}$

$\begin{array}{lll}1.2 & \text { Motief } & 10\end{array}$

$\begin{array}{lll}1.3 & \text { Aanpak } & 10\end{array}$

$\begin{array}{ll}\text { Toekomstscenario's } & 12\end{array}$

2.1 Scenario I - Langzaam verder 14

2.2 Scenario II - Pragmatisch duurzaam 14

2.3 Scenario III - Snel vooruit $\quad 14$

2.4 Scenario IV - Samen duurzaam $\quad 15$

$\begin{array}{lrr}3 & \text { Economie } & 16\end{array}$

$\begin{array}{lll}3.1 & \text { Huidige situatie } & 16\end{array}$

3.2 Toekomstscenario's $\quad 19$

3.2.1 Scenario I - Langzaam verder $\quad 21$

3.2.2 Scenario II - Pragmatisch duurzaam $\quad 22$

3.2.3 Scenario III - Snel vooruit $\quad 23$

3.2.4 Scenario IV - Samen duurzaam

4

\section{Ruimte}

$4.1 \quad$ Huidige situatie $\quad 25$

4.1.1 Zee- en windmolenvelden $\quad 25$

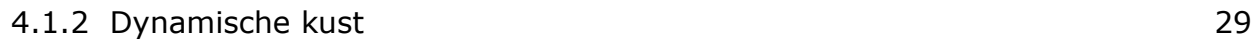

$\begin{array}{ll}4.1 .3 \text { Havens } & 36\end{array}$

$\begin{array}{lll}4.2 & \text { Toekomst scenario's } & 37\end{array}$

4.2.1 Scenario I - Langzaam verder 39

4.2.2 Scenario II - Pragmatisch duurzaam 42

4.2.3 Scenario III - Snel vooruit $\quad 43$

4.2.4 Scenario IV - Samen duurzaam

$\begin{array}{llr}5 & \text { Beleid en bestuur } & 47\end{array}$

5.1 Grote bestuurlijke drukte maar ook ruimte voor regie $\quad 47$

5.2 Overkoepelende beleids- en bestuur aanbevelingen $\quad 48$

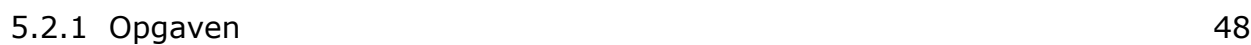

5.2.2 Rollen en verantwoordelijkheden $\quad 50$

$\begin{array}{ll}5.2 .3 \text { Beleidsinstrumenten } & 53\end{array}$ 
5.3 Het lerende vermogen van het netwerk van de Provincie Zuid-Holland

5.3.1 Proactief handelen op context vergt benutten van diversiteit van kennis

5.3.2 Organisatie van het interne en externe netwerk

$\begin{array}{lll}6.1 & \text { Conclusies } & 60\end{array}$

6.2 Aanbevelingen $\quad 60$

6.2.1 Beleidsproces: investeer in interne en externe regie $\quad 60$

$\begin{array}{ll}6.2 .2 & \text { Investeer in de kust }\end{array}$

6.2.3 Benut het potentieel van windmolenvelden op zee 63

6.2.4 Gebruik kracht Rotterdamse haven $\quad 65$

$\begin{array}{ll}\text { Literatuur en websites } & 67\end{array}$

$\begin{array}{lll}\text { Bijlage } 1 & \text { Methode } & 69\end{array}$

$\begin{array}{lll}\text { B1.1 Co-elaborative scenario building } & 69\end{array}$

$\begin{array}{ll}\text { B1.2 Stakeholder co-creatie } & 71\end{array}$

B1.3 Economic impacts $\quad 74$

B1.4 Landscape characterisation and mapping $\quad 74$

$\begin{array}{ll}\text { B1.5 Governance and policy analysis } & 75\end{array}$

$\begin{array}{lll}\text { Bijlage } 2 & \text { Trends \& ontwikkelingen } & 76\end{array}$

$\begin{array}{lll}\text { B2.1 Ecologie \& klimaat } & 76\end{array}$

$\begin{array}{ll}\text { B2.2 Recreatie } & 77\end{array}$

$\begin{array}{lll}\text { B2.3 } & \text { Maritiem transport } & 78\end{array}$

$\begin{array}{ll}\text { B2.4 Energie } & 79\end{array}$

B2.5 Voedsel $\quad 80$

$\begin{array}{lll}\text { Bijlage } 3 & \text { Visies, ambities en kansen } & 81\end{array}$

$\begin{array}{lll}\text { B3.1 Ecologie \& klimaat } & 81\end{array}$

$\begin{array}{ll}\text { B3.2 Recreatie } & 81\end{array}$

B3.3 Maritiem transport $\quad 82$

$\begin{array}{lll}\text { B3.4 Energie } & 83\end{array}$

B3.5 Voedsel $\quad 83$ 


\section{Woord vooraf}

De Provincie Zuid-Holland kent van oudsher een innige relatie met de Noordzee. Het gebruik van de Noordzee is aan grote veranderingen onderhevig. De traditionele gebruikers van de Noordzee moeten de beschikbare ruimte delen met nieuwe gebruikers en natuurontwikkeling. Gedreven door maatschappelijke opgaven ontstaan nieuwe maritieme sectoren, actief in het kustgebied en daarbuiten. De nieuwe ontwikkelingen op Noordzee kunnen bijdragen aan het realiseren van de Provinciale ambities, in het kustgebied en daarbuiten.

De ontwikkelingen op de Noordzee bieden kansen om de economie van de Provincie Zuid-Holland te versterken en de ruimtelijke omgevingskwaliteit te verbeteren. De ontwikkelingen die plaats vinden hebben, individueel of in samenhang met elkaar, invloed op (toekomstig) beleid van de Provincie ZuidHolland. Op basis van verwachte trends en ontwikkelingen, stakeholders' visies, ambities en kansen, toekomst scenario's en verwachte economische en ruimtelijke impacts evenals maatschappelijke opgaven, beleidsinstrumenten en rollen \& verantwoordelijkheden, worden no-regret beleidsaanbevelingen gedefinieerd rond ontwikkelingen en kansen gerelateerd aan activiteiten op zee, aan de kust en in de haven.

Met dit onderzoek krijgt de Provincie Zuid-Holland een beter inzicht in de ontwikkelingen op en rond de Noordzee die de provinciale ambities kunnen beïnvloeden en vormen, en worden onderwerpen geagendeerd voor het ontwikkelen van het toekomstige economische en ruimtelijke omgevingsbeleid van de Provincie Zuid-Holland.

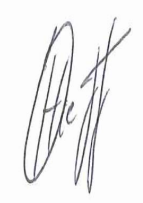

Ir. O. (Olaf) Hietbrink

Business Unit Manager Wageningen Economic Research

Wageningen University \& Research 


\section{Samenvatting}

\section{S.1 Kernvraag}

De Provincie Zuid-Holland kent van oudsher een innige relatie met de Noordzee. Het gebruik van de Noordzee is aan grote veranderingen onderhevig. De traditionele gebruikers van de Noordzee moeten de beschikbare ruimte delen met nieuwe gebruikers en natuurontwikkeling. Gedreven door maatschappelijke opgaven ontstaan nieuwe maritieme sectoren, actief in het kustgebied en daarbuiten. De nieuwe ontwikkelingen op zee kunnen bijdragen aan het realiseren van de Provinciale ambities, in het kustgebied en daarbuiten.

De ontwikkelingen op de Noordzee bieden kansen om de economie van de Provincie Zuid-Holland te versterken en de ruimtelijke omgevingskwaliteit te verbeteren. De ontwikkelingen die plaats vinden hebben, individueel of in samenhang met elkaar, invloed op (toekomstig) beleid van de Provincie ZuidHolland. Met dit onderzoek krijgt de Provincie Zuid-Holland een beter inzicht in de ontwikkelingen op en rond de Noordzee die de provinciale ambities kunnen beïnvloeden en vormen. Aan de hand van de onderzoeksresultaten agenderen wij onderwerpen voor het ontwikkelen van het toekomstige economische en ruimtelijke omgevingsbeleid van de Provincie Zuid-Holland.

\section{S.2 Boodschap}

De belangrijkste conclusies en aanbevelingen van deze studie zijn te vinden via onderstaande link naar de Visual. Hierin worden no-regret beleidsaanbevelingen rond ontwikkelingen en kansen op de Noordzee gerelateerd aan activiteiten op zee, aan de kust en in de haven.

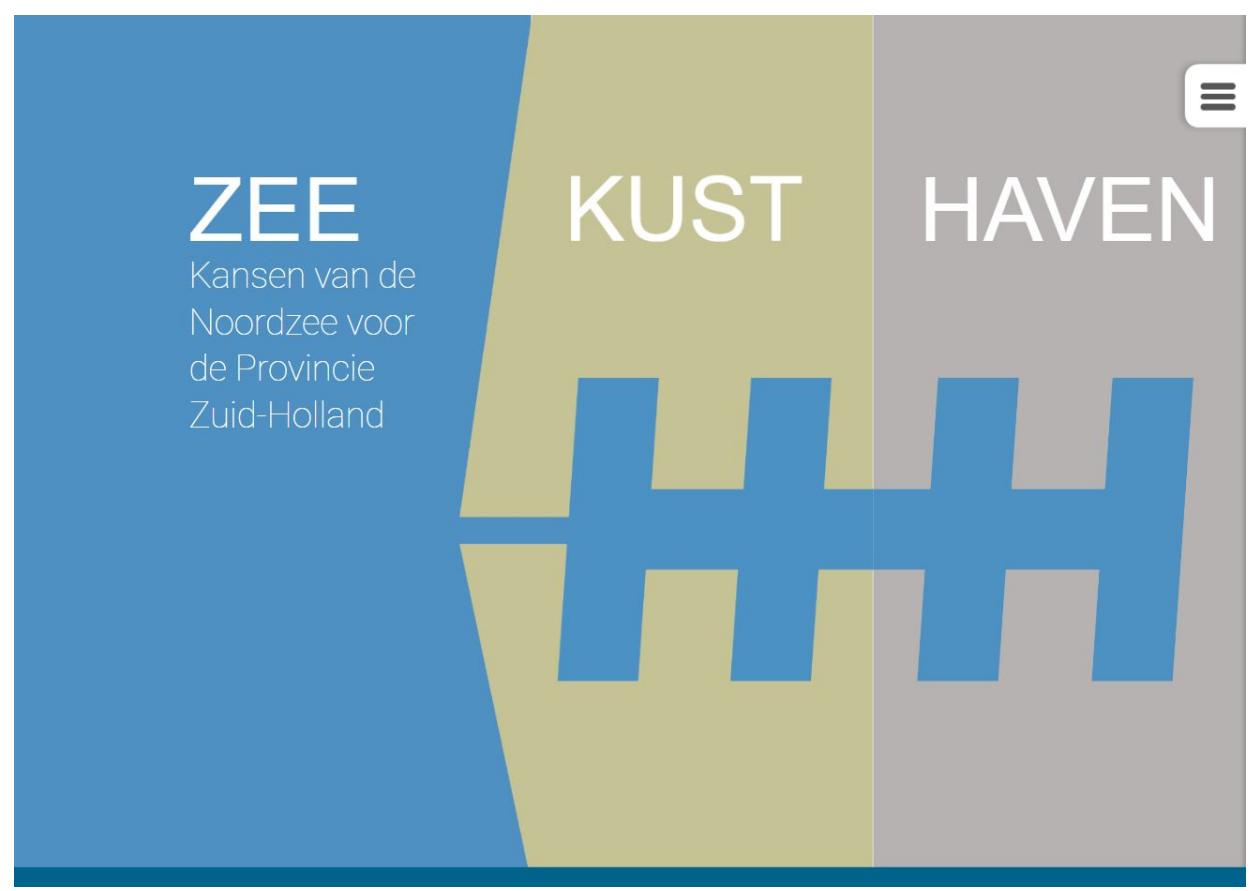

https://www.losstadomland.nl/Portals/0/noordzee3/index.html 


\section{S.3 Methodologie}

Voor deze studie maken we gebruik van de co-elaborative scenario building methodiek (zie bijvoorbeeld Bourgeois et al., 2017). Op basis van verwachte trends en ontwikkelingen op en rond de Noordzee en gerelateerde stakeholders' visies, ambities en kansen ontwikkelen we, uitgaande van de Noordzeescenario's ontwikkeld door PBL (2018, 2019), vier scenario's voor de toekomst voor de Provincie Zuid-Holland. Voor ieder van deze scenario's geven wij inzicht in de verwachte economische en ruimtelijke impacts evenals een overzicht van de maatschappelijke opgaven, de mogelijke beleidsinstrumenten en de gerelateerde rollen \& verantwoordelijkheden die deze scenario's met zich meebrengen. Deze scenario's vormen de basis voor de definitie van no-regret beleidsaanbevelingen rond ontwikkelingen en kansen gerelateerd aan activiteiten op zee, aan de kust en in de haven. 


\section{Summary}

\section{S.1 Key question}

The province of South Holland has long had a close relationship with the North Sea. Use of the North Sea is subject to significant changes. The traditional users of the North Sea must share the available space with new users and environmental development. Driven by social challenges, new maritime sectors develop that are active in the coastal area and beyond. The new developments at sea could contribute to the realisation of the provincial ambitions, in the coastal area and beyond.

The developments in the North Sea offer opportunities to strengthen the economy of the province of South Holland and to improve the quality of the spatial environment. The developments taking place have an effect - either individually or in conjunction with one another - on the present or future policy of the province of South Holland. This study gives the province of South Holland better insight into the developments in and around the North Sea that could influence and shape the provincial ambitions. We will use the research results to put topics on the agenda for the development of the future economic and spatial environmental policy of the province of South Holland.

\section{S.2 Message}

The main conclusions and recommendations of this study can be found via the link to the visual below. In this visual, no-regret policy recommendations focusing on developments and opportunities in the North Sea are related to activities at sea, on the coast and in the port.

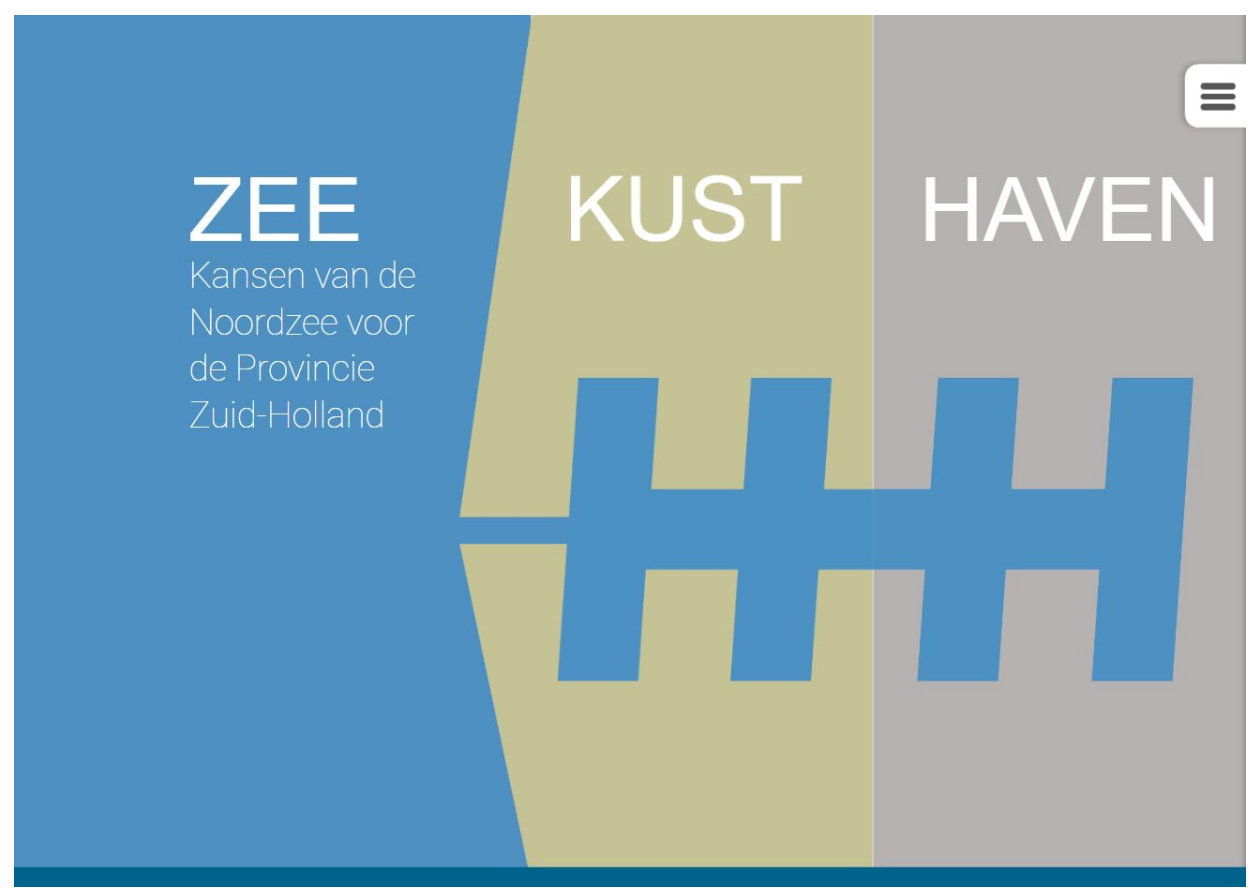

https://www.losstadomland.nl/Portals/0/noordzee3/index.html 


\section{S.3 Method}

For this study, we make use of the co-elaborative scenario building method (see, for example, Bourgeois et al., 2017). Based on expected trends and developments in and around the North Sea and related stakeholders' visions, ambitions and opportunities, we develop four future scenarios for the province of South Holland, taking the North Sea scenarios developed by PBL $(2018,2019)$ as a basis. For each of these scenarios, we provide insight into the expected economic and spatial impacts as well as an overview of the social challenges, the possible policy instruments and the related roles and responsibilities that these scenarios entail. These scenarios form the basis for the definition of noregret policy recommendations focusing on developments and opportunities related to activities at sea, on the coast and in the port. 


\section{$1 \quad$ Introductie}

\section{$1.1 \quad$ Aanleiding}

De Provincie Zuid-Holland kent van oudsher een innige relatie met de Noordzee. De kustlijn van 65 kilometer en badplaatsen als Noordwijk, Scheveningen en Ouddorp bieden mogelijkheden tot recreatie. Vissersplaatsen als Katwijk en Scheveningen hebben een belangrijke cultuurhistorische waarde en dragen bij aan de voedselvoorziening en economische welvaart. Het Rotterdamse havengebied is een economische motor voor Nederland en bood in 2017 directe werkgelegenheid aan 121.800 mensen; indirect droeg de haven bij aan werkgelegenheid voor 262.700 mensen (Erasmus Universiteit, 2018). Het Nationaal Park Hollandse Duinen is een belangrijk natuurgebied en de Zandmotor laat zien dat kustbescherming en Building with Nature succesvol samen kunnen gaan.

Het gebruik van de Noordzee is aan grote veranderingen onderhevig. De traditionele gebruikers van de Noordzee - vissers, reders, kustbeschermers, olie- en gasbedrijven en het Defensie - moeten de beschikbare ruimte delen met nieuwe gebruikers en natuurontwikkeling. Gedreven door maatschappelijke opgaven als klimaatbeleid, voedselzekerheid of natuurbescherming ontstaan nieuwe maritieme sectoren, actief in het kustgebied en daarbuiten. Voorbeelden daarvan zijn de offshore windsector en de productie van voedsel uit zee (zie Van den Burg et al., 2021).

De nieuwe ontwikkelingen op zee kunnen bijdragen aan het realiseren van de Provinciale ambities, in het kustgebied en daarbuiten. De Strategische Agenda Kust Zuid-Holland beschrijft de ambitie om samen met de stakeholders een natuurlijke, aantrekkelijke en duurzame kust te realiseren. De Nota Van Investeren in Zuid-Holland plukt Nederland de vruchten schetst een perspectief op de transitie van de economie van Zuid-Holland.

\subsection{Motief}

De ontwikkelingen op de Noordzee bieden kansen om de economie van de Provincie Zuid-Holland te versterken en de ruimtelijke omgevingskwaliteit te verbeteren. De ontwikkelingen die plaatsvinden hebben, individueel of in samenhang met elkaar, invloed op (toekomstig) beleid van de Provincie ZuidHolland. Met dit onderzoek krijgt de Provincie Zuid-Holland een beter inzicht in de ontwikkelingen op en rond de Noordzee die de provinciale ambities kunnen beïnvloeden en vormen. Aan de hand van de onderzoeksresultaten agenderen wij onderwerpen voor het ontwikkelen van het toekomstige economische en ruimtelijke omgevingsbeleid van de Provincie Zuid-Holland.

\subsection{Aanpak}

Voor deze studie maken we gebruik van de co-elaborative scenario building methodiek (zie bijvoorbeeld Bourgeois et al., 2017). Op basis van verwachte trends en ontwikkelingen op en rond de Noordzee en gerelateerde stakeholders' visies, ambities en kansen ontwikkelen we, uitgaande van de Noordzeescenario's ontwikkeld door PBL (2018, 2019), vier scenario's voor de toekomst voor de Provincie Zuid-Holland. Voor ieder van deze scenario's geven wij inzicht in de verwachte economische en ruimtelijke impacts evenals een overzicht van de maatschappelijke opgaven, de mogelijke beleidsinstrumenten en de gerelateerde rollen \& verantwoordelijkheden die deze scenario's met zich meebrengen. Deze scenario's vormen de basis voor de definitie van no-regret beleidsaanbevelingen rond ontwikkelingen en kansen gerelateerd aan activiteiten op zee, aan de kust en in de haven. Zie Bijlage 1 voor gedetailleerde informatie met betrekking tot de aanpak. 
In dit rapport worden vier scenario's voor de toekomst voor de Provincie Zuid-Holland beschreven (hoofdstuk 2). In hoofdstuk Error! Reference source not found. worden de huidige economische situatie en de verwachte economische impacts van de vier scenario's voor de Provincie Zuid-Holland beschreven; in hoofdstuk Error! Reference source not found. worden de huidige ruimtelijke situatie en de verwachte ruimtelijke impacts van de vier scenario's beschreven. Hoofdstuk 5 geeft een overzicht van de maatschappelijke opgaven, de gerelateerde rollen en verantwoordelijkheden, en beleidsinstrumenten van de provincie en relevante actoren die deze opgaven met zich meebrengen, daarbij kijkend naar het lerend vermogen van het provincienetwerk evenals de verschillen en overeenkomsten tussen de vier toekomstscenario's. Conclusies en beleidsaanbevelingen volgen, tot slot, in hoofdstuk 6. 


\section{Toekomstscenario's}

Dit hoofdstuk beschrijft, op basis van de huidige situatie en de toekomstige trends \& ontwikkelingen op de Noordzee (zie Bijlage 2) en de hieruit volgende stakeholders' visies, ambities en kansen/ bedreigingen (zie Bijlage 3), vier scenario's voor de toekomst voor de Provincie Zuid-Holland. Als uitgangspunt hiervoor nemen we de Noordzeescenario's ontwikkeld door PBL $(2018,2019)$ - zie Bijlage 1 (B1.1) voor gedetailleerde informatie.

De Noordzeescenario's ontwikkeld door PBL, staan uitgebreid beschreven in PBL (2018) en onderbouwd in PBL (2019). Figuur 1 geeft een overzicht van de belangrijkste kenmerken van deze scenario's voor Nederland evenals de additionele kenmerken relevant voor de Provincie Zuid-Holland zoals deze naar voor zijn gekomen in de eerste ronde van workshops (WS-Fase1). De Scenario's I (Langzaam verder) en IV (Samen duurzaam) vormen de twee extremen, terwijl de Scenario's II (Pragmatisch duurzaam) en III (Snel vooruit) tussenliggende scenario's vormen.

Relevante additionele kenmerken voor de Provincie Zuid-Holland hebben betrekking tot visserij en verwerking, aquacultuur en verwerking, verzilting in landbouw, aanvoer voor en aanlanding van wind(-energie) op zee (WOZ) en/of carbon-capture \& storage (CCS), statisch en dynamisch kustbeheer en, tot slot, toerisme en recreatie op land, aan kust en op zee.

De belangrijkste variabelen in de scenario's zijn klimaatverandering, Brexit, energietransitie, kustbeheer en natuurnetwerken. Klimaatverandering is afhankelijk van het al dan niet behalen van de klimaatdoelstellingen gedefinieerd in de Paris agreement in 2015. Hoewel analisten zeggen dat het pact heeft geholpen vooruitgang te boeken in de richting van het doel om te voorkomen dat de gemiddelde temperatuur op aarde met $2{ }^{\circ} \mathrm{C}$ boven pre-industriële niveaus stijgt, wordt de inspanning ook overschaduwd door het bewijs dat veel landen de beloften die ze in 2015 hebben gedaan niet nakomen (Cornwall, 2020).

De Brexit is sinds 31 januari 2020 een feit en in het bereikte akkoord staan afspraken en regels die vanaf 1 januari 2021 gelden. ${ }^{1}$ In relatie tot de Noordzee zijn de volgende punten van belang. Ten eerste, geen tarieven of quota op handel; wel handel onder strikte voorwaarden (bijvoorbeeld extra documenten aan de grens); goederen uit het VK moeten blijven voldoen aan de EU wet- en regelgeving. Ten tweede, EU-vissers houden nog 5,5 jaar toegang tot Britse wateren; stapsgewijs mogen ze tot 25\% minder vis vangen in Britse Wateren; na deze overgangsperiode volgt jaarlijks een VK besluit over de toegang voor EU-vissers. Ten derde, het VK vertrekt uit de EU interne energiemarkt; afspraken over energiehandel, interconnectiviteit en energiesamenwerking (onder andere op de Noordzee); samenwerking om klimaatdoelen te halen.

De energietransitie is noodzakelijk om aan de afspraken van de Paris agreement te voldoen (RIVM, 2021). Hiervoor moet Nederland overstappen van fossiele brandstoffen (zoals kolen, olie en gas) naar duurzame energiebronnen (zoals zon- en windenergie). Het (ontwerp-)Klimaatakkoord legt de maatregelen en afspraken voor deze energietransitie vast. Het doel van het Klimaatakkoord is een vermindering van broeikasgassen met $49 \%$ in 2030 en met $95-100 \%$ in 2050.

Voor de uitdagingen rond kustveiligheid, de omgang met onzekerheden en het meervoudig gebruik van de kust, hebben de gezamenlijke overheden van de stuurgroep Deltaprogramma Kust de Nationale Visie Kust gedefinieerd (I\&M, 2013). In deze visie leggen de partijen de veiligheidsopgaven en de ruimtelijke ambities uit, en is de koers gericht op het verbinden van opgaven, met maatwerk per locatie. Samenwerking gebeurt onder meer via het Kustpact (I\&W, 2017), waar overheden, natuurorganisaties, de recreatiesector en drinkwaterbedrijven in deelnemen. Het zwaartepunt ligt bij veiligheid en de relatie tussen veiligheid en ruimtegebruik.

\footnotetext{
1 zie https://www.rijksoverheid.nl/onderwerpen/brexit/brexit-stand-van-zaken
} 


\section{Duurzame ambitie}

\section{Pragmatisch duurzaam}

Intern.: Handelsblokken domineren; Klimaatafspraken worden $100 \%$ uitgevoerd

Beleid: $\quad$ Groene groei; Minder harde Brexit; $80 \%$ minder BGE t.o.v. 1990

$\begin{array}{ll}\text { Energie: } & \text { Kleine toename WOZ (22 GW); Olie \& gas worden uitgeput; CO2 opslag (30 MT) } \\ \text { Infrastr.: } & \text { Olie \& gas wordt opgeruimd en beperkt vervangen door CCS }\end{array}$

Scheepvaart: Geen verandering in scheepvaartbewegingen ( $+20 \%$ tot 2050); Duurzame

Natuur: Realisering van Naturnetwerk Nederland: Matige greei biodiversiteit

Voedsel: $\quad$ Enige afname traditionele visserij; Visserij beperkt innovatief (vangsttechnieken: enig medegebruk WOZ); Aquacultur neemt sterk toe (plant; medegebruik WOz, $200 \mathrm{~km} 2$ ); Lage verzilting landbouw; Kleine verduurzaming consumptie

Zandwinning: 30 milj. $\mathrm{m}^{3}$

Recreatie: Vaartuigen op zee nemen af; Voorkeur andere recreatievormen; Aan kust neemt toe; WOZ toerisme neemt toe; Eco-recreatie neemt toe; Kwaliteit neemt toe

Dynamisch (zacht) en statisch (hard; onderhoud) kustbeheer

verwerking: $\quad$ WOZ (8 GW); Aquacultuur (50\%); Visserij (9\%)

\section{Samen duurzaam:}

Intern.: Globalisering gaat voort; Klimaatafspraken $100 \%$ uitgevoerd

Circulaire economie; Akkoord+ UK; 100\% minder BGE t.o.v. 1990

Energie: Max. toename $W O Z$ ( $60 \mathrm{GW})$; Olie \& gas snel onrendabel; CO2 opslag (50 MT)

Infrastr.: Olie \& gas wordt opgeruimd en vervangen door CCS; Energie eilanden

scheepvaart; Grote havens versterken positie maar breiden niet uit

Natur: $\quad$ Realisering van internationaal natuurnetwerk; Sterke groei biodiversiteit Sterke afname traditionele visserij. Visserij sterk innovatief (omslag naar aquacultuur; medegebruik WOZ): Aquacultur neemt zeer sterk toe (medegebruk WOZ, $400 \mathrm{~km} 2)$; Minimale verzlting landbouw; Sterke verdurzaming consumptie

Zandwinning: 40 milj. $\mathrm{m} 3$

Recreatie: Vaartuigen op zee nemen toe; Aan kust neemt sterk toe; WOZ en eilanden

toerisme neemt toe; Eco-recreatie neemt toe; Kwaliteit kan botsen met kwantiteit

Kustbeheer: - Dynamisch (zacht) en statisch (hard; onderhoud) kustbeheer

WOZ (10 GW); Aquacultuur (75\%); Visserij $(8 \%)$

\section{Lage dynamiek}

\section{Langzaam verde}

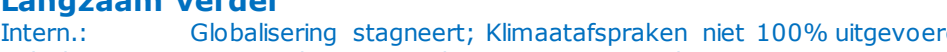

Beleid: $\quad$ Groei en banen; Harde Brexit; 45\% minder BGE t. ov. 1990

Energie: Min. toename WOZ (12 GW); Olie \& gas worden uitgeput; Geen CO2 opslag

Infrastr.: $\quad$ Olie \& gas blijt tot na 2030

Scheepvaart: Verschuiving naar noorden en groei $(+20 \%$ tot 2050$)$; Kleine verduurzamin scheepvaart; Grote havens behouden positie maar breiden niet uit

Natuur: $\quad$ Zelfde natuurgebieden als in 2015; Lage groei biodiversiteit

Voedsel: Kleine afname traditionele visserij; Visserij beperkt innovatief (vangsttechnieken geen medegebruik WOZ); Aquacultuur neemt beperkt toe (medegebruik WOZ, 25 $\mathrm{km} 2$ ); Sterke verzilting landbouw; Minimale verandering in consumptie

\section{Zandwinning: 60 milj. $\mathrm{m} 3$}

Recreatie: Vaartuigen op zee nemen sterk af; Aan kust neemt af; Geen WOZ toerisme; Kustbeheer: Max. statisch (hard) i.c.m. dynamisch (zacht) kustbehee
O\&M:

WOZ (6 GW); Aquacultuur (50\%); Visserij (10\%)

\section{Hoge dynamiek}

\section{Snel vooruit:}

Intern.: Globalisering gaat voort; Klimaatafspraken niet 100\% uitgevoerd

Beleid: Materïle welvaart; Akkoord UK. $65 \%$ minder BGE t. $0 . v$. 1990

Energie: Grote toename WOZ (32 GW); Deel olie \& gas blijt onbenut; CO2 opslag (25 MT)

Infrastr.: $\quad$ Olie \& gas wordt opgeruimd en deels vervangen door CCS

Scheepvaart: Verschuiving naar noorden en groei ( $+40 \%$ tot 2050$)$; Kleine verduurzaming

scheepvaart; Grote havens behouden positie en breiden uit

Voedsel: $\quad$ Matige afname traditionele visserij; Visserij sterk innovatief (vangsttechnieken; medegebruik WOZ); Aquacultuur neemt sterk toe (dier; medegebruik WOZ, 100 $\mathrm{km} 2$ ); Matige verzilting landbouw; Geen verandering in consumptie

\section{Zandwinning: 75 milj. m3}

Recreatie: Vaartuigen op zee nemen toe; Aan kust blijt gelijk; WOZ toerisme neemt toe;

Kustbeheer: Max. statisch (hard) i.c.m. max. dynamisch (zacht) kustbeheer

O\&M:

Verwerking: WOZ $(10 \mathrm{GW})$; Aquacultuur $(50 \%)$; Visserij $(8,5 \%)$

\section{Vaststaand beleid (2015/2030)}

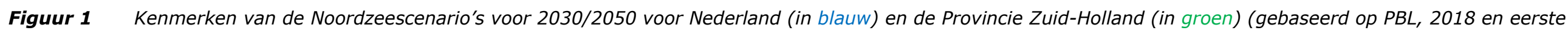
ronde van workshops (WS-Fase1)) 
Tot slot, de ontwikkelingen rond natuurnetwerken worden in belangrijke mate bepaald door afspraken gedefinieerd in de Europese Kaderrichtlijnen, zoals de Kaderrichtlijn natuur (Richtlijn 92/43/EEG) ${ }^{2}$, de Kaderrichtlijn vogels (Richtlijn 2009/147/EG), ${ }^{3}$ de Kaderrichtlijn water (Richtlijn 2000/60/EG) ${ }^{4}$ en de Kaderrichtlijn maritieme ruimtelijke planning (Richtlijn 2014/89/EU). ${ }^{5}$

\subsection{Scenario I - Langzaam verder}

Langzaam verder (PBL, 2018: p.37): In dit scenario stagneert de globalisering door toenemende internationale conflicten en toenemend nationalisme. Omdat gevestigde belangen steeds meer voorop komen te staan, krijgen innovaties weinig kans en verloopt de technologische ontwikkeling traag. Het Nederlandse en Europese beleid worden meer gericht op het bevorderen van economische groei en banen. De sectoren die op de Noordzee actief zijn, worden nauwelijks duurzamer en op termijn neemt windenergie op zee weinig toe. Er is een afname van toerisme maar wel van een verhoogd kwaliteit, met minder intensief ruimte gebruik voor recreatie en toerisme en renovatie/upgraden van de bestaande ruimte. De mondiale klimaatafspraken van Parijs worden maar gedeeltelijk nagekomen, en een langzame verduurzaming versterkt de zeespiegelstijging en de vraag naar harde ingrepen aan de kust. Ook de energietransitie verloopt traag en er verandert weinig in het ruimtegebruik in de haven (olie, gas en bijproducten blijven belangrijk) en is er minder behoefte aan wind op zee (WOZ). Doordat ook de aquacultuur beperkt toeneemt zal de druk op de ruimte tussen de windmolenvelden zich niet snel ontwikkelen. Wel zal er enige ruimte worden ingenomen door aquacultuur. Er worden geen extra gebieden aangewezen met belangrijke natuurwaarden en dus blijft de druk op de ruimte op zee beperkt vanuit dit opzicht.

\subsection{Scenario II - Pragmatisch duurzaam}

Pragmatisch duurzaam (PBL, 2018: p.42): Ook in dit scenario is er minder economische groei door een haperende globalisering, een trage technologische vooruitgang en met beperkte concurrentie. In het licht van de klimaatafspraken zijn er wel initiatieven voor groene innovaties, waardoor de mondiale temperatuurstijging beperkt blijft. Het Europese en nationale beleid zijn gericht op een vitale economie, maar niet per se op een hoge groei. De ambities dragen bij aan een verduurzaming van de sectoren die actief zijn op de Noordzee en de realisering van veel windenergie en $\mathrm{CO}_{2}$-opslag op zee. De ontwikkelingen leiden tot een sterke (jaarrond) groei van het ruimtebeslag van de recreatiesector in Zuid-Holland, met druk op de ruimte die voor recreatie is bestemd. Het kustbeheer is gericht op kennisontwikkeling en er is ruimte en tijd om nieuwe dingen te proberen. Door de kleine toename van wind op zee blijven delen beschikbaar die nog niet geoccupeerd zijn. En doordat aquacultuur sterk toeneemt, maar de havenactiviteiten niet uitbreiden en er nog geen energiehubs zullen komen, zal de ruimte tussen de windmolenvelden vooral worden geoccupeerd door aquacultuur. Met een uitbreiding van het Nederlands Natuurnetwerk worden gebieden aangewezen waar restricties van toepassing zijn. Hierdoor neemt de druk op de ruimte toe. Er is minder visserij.

\subsection{Scenario III - Snel vooruit}

Snel vooruit (PBL, 2018: p.46): De versnelde globalisering en technologische ontwikkeling stimuleren de economische groei met meer strikte klimaatafspraken. Zowel het Europese als nationale beleid blijft gericht op duurzaamheid, maar materiële welvaart krijgt een groter accent. De sectoren die actief zijn op zee worden niet veel duurzamer, maar doordat windenergie op zee winstgevend wordt, nemen de windambities wel sterk toe. Op de Doggersbank verschijnt een eiland dat als energie-hub dient. Er is meer toerisme gerelateerd aan wind op zee (zoals recreatieve excursies en sportvisserij), maar recreatie aan de kust blijft gelijk; in totaal een toename van het ruimtebeslag van de

\footnotetext{
2 https://eur-lex.europa.eu/legal-content/EN/TXT/?uri=CELEX:31992L0043 
recreatiesector in Zuid-Holland. Er is een snelle energietransitie, olie \& gas stopt, met een sterke daling van het ruimtebeslag in de energiesector tot gevolg. Dit werkt ook door in andere sectoren, aangezien ook de bijproducten van olie \& gas komen te vervallen. Er komt dus veel ruimte beschikbaar in het havengebied. Er is groei in de scheepvaart, en een stijging van de werkgelegenheid en het ruimtebeslag in de logistieke sector. $\mathrm{Er}$ is een grote toename van wind op zee, en ook $\mathrm{CO}_{2}$ opslag, met een sterke toename van het aantal banen en het ruimtebeslag op zee. Doorwerking zorgt voor een lichte toename in andere sectoren, zoals offshore, aanleg van kabels en buizen en toerisme. $\mathrm{Er}$ is een matige afname in de visserij en een sterke stijging van aquacultuur. De grootschalige (zoute) aquacultuur in Nederland blijft relatief onrendabel.

\subsection{Scenario IV - Samen duurzaam}

Samen duurzaam (PBL, 2018: p.50): Een verdergaande globalisering en een snelle technologische ontwikkeling stimuleren de economische groei. Het consequent nakomen van de klimaatafspraken draagt bij aan de beperking van de temperatuurstijging. Het Europese en Nederlandse beleid zijn gericht op het realiseren van een transitie naar een circulaire economie. De sectoren die actief zijn op de Noordzee worden veel duurzamer en er komen veel nieuwe windparken in combinatie met andere vormen van hernieuwbare energie. Er verschijnen eveneens een aantal eilanden die als energie-hubs dienen. Er een toename van toerisme gerelateerd aan wind op zee (zoals recreatieve excursies en sportvisserij) en ecotoerisme zichtbaar. Ook overige (jaarrond) recreatie aan de kust neemt toe. De ontwikkelingen leiden tot een sterke toename van het ruimtebeslag van de recreatiesector in ZuidHolland. De transitie naar duurzame energiebronnen verloopt snel. Winning en het gebruik van olie \& gas wordt snel onrendabel, met een sterke daling van het ruimtebeslag in de energiesector tot gevolg. Dit werkt ook door in andere sectoren. Er is groei in de scheepvaart met een lichte toename van het ruimtebeslag. $\mathrm{Er}$ is een maximale toename van wind op zee, en ook $\mathrm{CO}_{2}$-opslag, met een sterke toename van het ruimtebeslag van de sector, met een lichte toename zichtbaar in andere sectoren, zoals offshore, aanleg van kabels en buizen en toerisme. Er is een sterke afname in de visserij en een sterke stijging van aquacultuur. Aangezien aquacultuur relatief ruimte-intensiever is dan de visserij, neemt het totale ruimtebeslag van de sector wel toe. 


\section{Economie}

Dit hoofdstuk brengt in beeld de huidige economische situatie (Sectie 3.1) en de verwachte economische impacts van de vier scenario's (Sectie 3.2) voor de Provincie Zuid-Holland. De economische situatie is beschreven per sector (Ecologie \& klimaat; Recreatie; Maritiem transport; Energie; Voedsel) op basis van data uit het Landelijk Informatiesysteem van Arbeidsplaatsen (LISA, 2020), en met indicatoren voor werkgelegenheid en bruto vloeroppervlak ${ }^{6}$ (zie Bijlage 1: B1.3).

\subsection{Huidige situatie}

In totaal waren in 2019 in Zuid-Holland circa 130 duizend banen op een of andere manier aan de Noordzee gerelateerd (zie Tabel 1). Dat gaat om 7,3\% van het totale aantal banen in Zuid-Holland. Van de sectoren met een relatie tot de Noordzee is de recreatiesector met circa 75.000 banen het grootst. Ook de sector ecologie \& klimaat is met circa 40.000 banen een relatief grote sector.

Tabel 1 Aantal banen per sector en aandeel in Zuid-Holland

\begin{tabular}{lrr} 
& Aantal banen & Aandeel (\%) \\
Ecologie \& Klimaat & 39.072 & 2,2 \\
\hline Recreatie & 74.622 & 4,2 \\
\hline Energie & 7.780 & 0,4 \\
\hline Voedsel & 1.616 & 0,1 \\
\hline Maritiem Transport & 7.188 & 0,4 \\
\hline Totaal Noordzee gerelateerd & 130.278 & 7,3 \\
\hline Overig & 1.644 .312 & 92,7 \\
\hline Totaal Zuid-Holland & 1.774 .590 & \\
\hline
\end{tabular}

Bron: LISA (2020); bewerking Ecorys.

Hierna gaan we per sector in op de werkgelegenheid (banen) en op het bruto vloeroppervlak (bvo). Daarbij wordt gekeken naar regionale spreiding en de ontwikkeling in de afgelopen jaren. Daarnaast wordt een doorkijk gegeven naar verwachte trends en ontwikkelingen in de toekomst.

\section{Ecologie \& klimaat}

Het merendeel van de banen in de sector ecologie \& klimaat is gevestigd in de regio Haaglanden (Figuur 2). De totale werkgelegenheid in de sector ecologie \& klimaat is in de afgelopen jaren licht toegenomen. Die toename is in alle regio's zichtbaar, maar het sterkst in de regio's Haaglanden en Rotterdam (Figuur 2). Ook het ruimtebeslag voor de sector is toegenomen. De sector wint dus duidelijk aan belang. Wanneer specifiek naar kustgemeenten gekeken wordt valt op dat de sector ecologie \& klimaat verwaarloosbaar aanwezig is, met uitzondering van architecten, ingenieurs en technisch ontwerp en advies in Den Haag.

Door de gevolgen van klimaatverandering neemt de urgentie van het nemen van adaptatie- en mitigatiemaatregelen toe. Architecten en adviesbureaus zullen in toenemende mate werken aan innovatieve oplossingen om Nederland in de toekomst leefbaar te houden, bijvoorbeeld door het aanleggen en onderhouden van kustverdediging. Gezien de projectmatigheid van dit werk is het echter onzeker in welke mate deze trend door zet. Daarnaast zal door een toename in windenergie (en

6 Het brutovloeroppervlakte (BVO) is het vloeroppervlak van de ruimte, dan wel van meerdere ruimten van een vastgoedobject gemeten (volgens NEN 2580) op vloerniveau langs de buitenomtrek van de (buitenste) opgaande scheidingsconstructie, die de desbetreffende ruimte(n) omhullen (zie https://www.keurhuisnederland.nl/wat-is-het-brutovloeroppervlak-bvo/). 
de uitbreiding van het elektriciteitsnetwerk in het algemeen) de vraag naar het leggen van kabels toenemen.
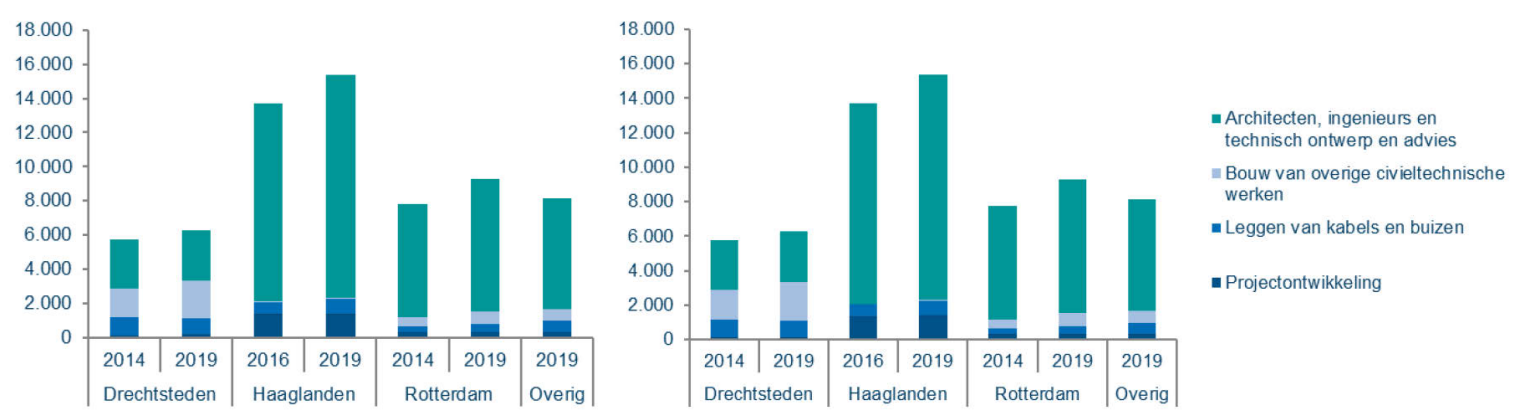

Figuur 2 Werkgelegenheid (links) en brutovloeroppervlak (bvo) (rechts) in de sector Ecologie \& klimaat

Bron: LISA (2020); bewerking Ecorys.

\section{Recreatie}

De recreatiesector is de grootste (deels) aan de Noordzee gerelateerde sector. Hieronder vallen bijvoorbeeld accommodaties als hotels-restaurants, jeugdherbergen, kampeerterreinen en logiesverstrekkingen, maar ook jachthavens en verstrekkers van dagtochten zoals surfscholen, verzorgers van vistochten. Cafés en restaurants hebben hierin het grootste aandeel (meer dan $50 \%$ ) in de sector. Het merendeel van de banen in de sector is gevestigd in de regio Haaglanden (Figuur 3). De totale werkgelegenheid in de sector recreatie is in de afgelopen jaren toegenomen. Die toename is in alle regio's zichtbaar, maar het sterkst in de regio Rotterdam. Ook het ruimtebeslag voor de sector is in deze regio sterk toegenomen, met name door groei in restaurants en cafetaria's (Figuur 3). De kustgemeenten hebben slechts een beperkt aandeel in recreatie wat betreft werkgelegenheid en ruimtebeslag, met uitzondering van de gemeente Den Haag. In deze gemeenten is het overgrote deel van werkgelegenheid in restaurants en cafetaria's te vinden.

De groei in kustrecreatie en toerisme zet in de toekomst naar verwachting door. Belangrijke aanjagers hiervoor zijn, onder andere, hete(re) zomers en bevolkingsgroei. Daarnaast is de uitbreiding van wind op zee (WOZ) aantrekkelijk voor een bepaalde groep toeristen.
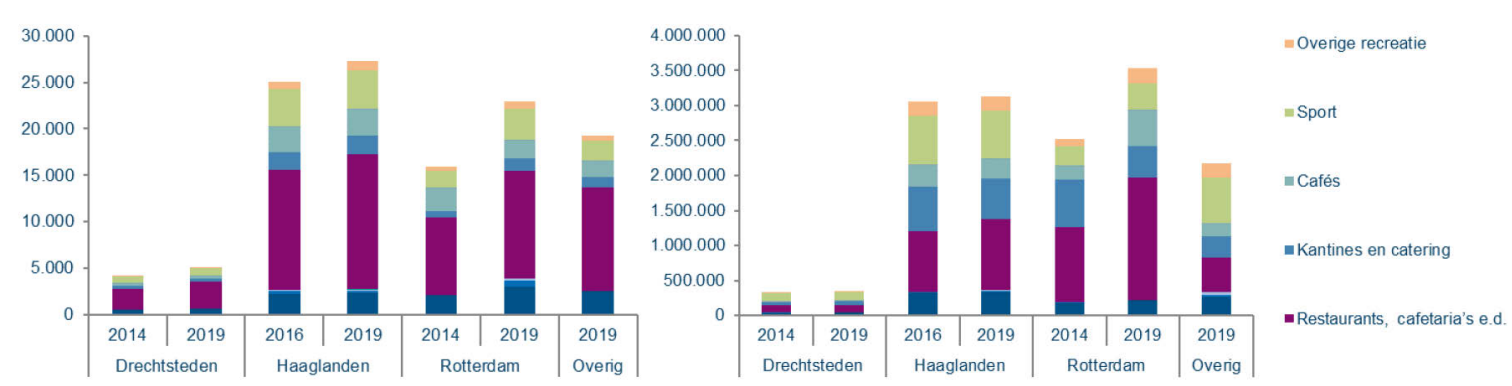

Figuur 3 Werkgelegenheid (links) en brutovloeroppervlak (bvo) (rechts) in de sector Recreatie Bron: LISA (2020); bewerking Ecorys.

\section{Energie}

In de energiesector is over de afgelopen jaren een lichte stijging zichtbaar in de werkgelegenheid (Figuur 4). Wat betreft ruimtebeslag is een sterkere stijging zichtbaar, met name in Rotterdam (Figuur 4). De hele (op een of andere manier aan zee-gerelateerde) energiesector in Zuid-Holland kent circa 7 duizend arbeidsplaatsen, en is dus niet heel omvangrijk. Circa $70 \%$ van de werkgelegenheid in de sector is gerelateerd aan de distributie van elektriciteit en gas via leidingen. Daarnaast is circa $27 \%$ toe te schrijven aan beheer en exploitatie van transportnetten en handel via leidingen. De overige $3 \%$ bestaat grotendeels uit werkgelegenheid gerelateerd aan productie van 
thermische, kern- en warmtecentrales, productie van zonnecellen, warmtepompen en waterkracht en productie van elektriciteit door windenergie. De productie van elektriciteit door windenergie heeft echter een zeer klein aandeel. Het aandeel Wind op Zee is dus zeer klein. Afgaande op de standaardbedrijfsindeling (SBI-)classificatie (CBS, 2020) is de hieraan gerelateerde werkgelegenheid verwaarloosbaar. Daarbij moet opgemerkt worden dat dit beeld deels is vertekend, doordat de SBIclassificatie op bedrijfsniveau en niet op arbeidsplaatsniveau wordt gemaakt. Daarnaast is veel gerelateerd werk in andere sectoren te vinden (bijvoorbeeld offshore en energie) of betreft het tijdelijke werkgelegenheid. Specifiek voor de kustgemeenten valt verder op dat de sector energie naast productie van elektriciteit niet of nauwelijks aanwezig is.

De trends en ontwikkelingen binnen de energiesector zijn sterk afhankelijk van het verloop van de energietransitie. De omschakeling naar een duurzame energievoorziening heeft met name impact op de aardgassector, welke naar verwachting sterk of geheel afneemt. Meer duurzame vormen van energie, zoals waterstof of windenergie, zullen juist sterk toenemen.
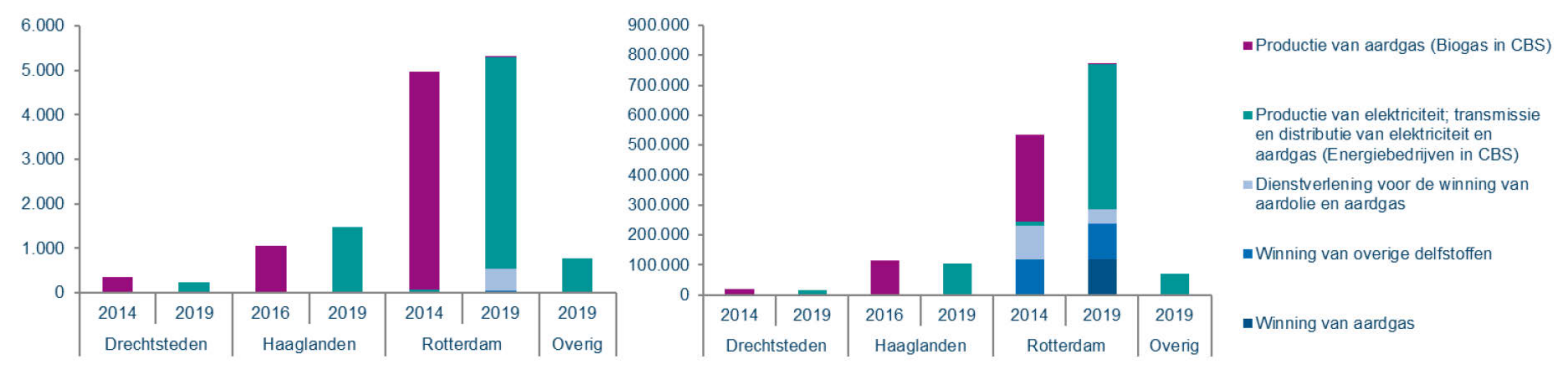

Figuur 4 Werkgelegenheid (links) en brutovloeroppervlak (bvo) (rechts) in de sector Energie Bron: LISA (2020); bewerking Ecorys.

\section{Voedsel}

In de voedselsector is de afgelopen jaren een lichte stijging zichtbaar in de werkgelegenheid (Figuur 5). Die stijging is het sterkst zichtbaar in de regio Rotterdam. Het totale ruimtebeslag in de Provincie Zuid-Holland is daarentegen juist licht afgenomen (Figuur 5). Opvallend daarbij is dat toename te zien is in Rotterdam en lichte daling in Den Haag. Overigens valt ook op dat visserij in de cijfers nauwelijks aanwezig is. Er is wel relatief veel visverwerking in de kustgemeenten gevestigd.

Trends en ontwikkelingen in visserij en visverwerking zijn sterk afhankelijk van de invloed van de Brexit en de mate van innovatie en aquacultuur. De Brexit-afspraken over visserij leiden ertoe dat Nederlandse vissers een kwart minder vis mogen vangen dan voorheen. Dat is van grote invloed op de visserijsector en werkt ook door in de visverwerkingsketen. Op gebied van aquacultuur is Nederland nog een kleine speler. In Nederland vindt het kweken van vis nog slechts in enkele tientallen bedrijven plaats. De zoute teelt, de teelt van zoutwatervis en andere zilte producten zoals zeewier, is kleinschalig en in ontwikkeling. Gezien de huidige kleinschaligheid van de Nederlandse viskweeksector en de relatief extensief geproduceerde bulkproducten uit het buitenland, is het niet aannemelijk dat de sector zich de komende jaren grootschalig uitbreidt. Wel liggen er kansen voor meervoudig ruimtegebruik, zoals de combinatie wind op zee met aquacultuur, en de kweek van exclusieve en/of streekproducten voor nichemarkten (Rijksoverheid, 2015). Daarnaast zal zeespiegelstijging in bepaalde gebieden zorgen voor verzilting van de landbouwbodem. Als gevolg is een transitie naar klimaatbestendige gewassen, zoals zeewier, een te verwachten ontwikkeling in kustgebieden. 

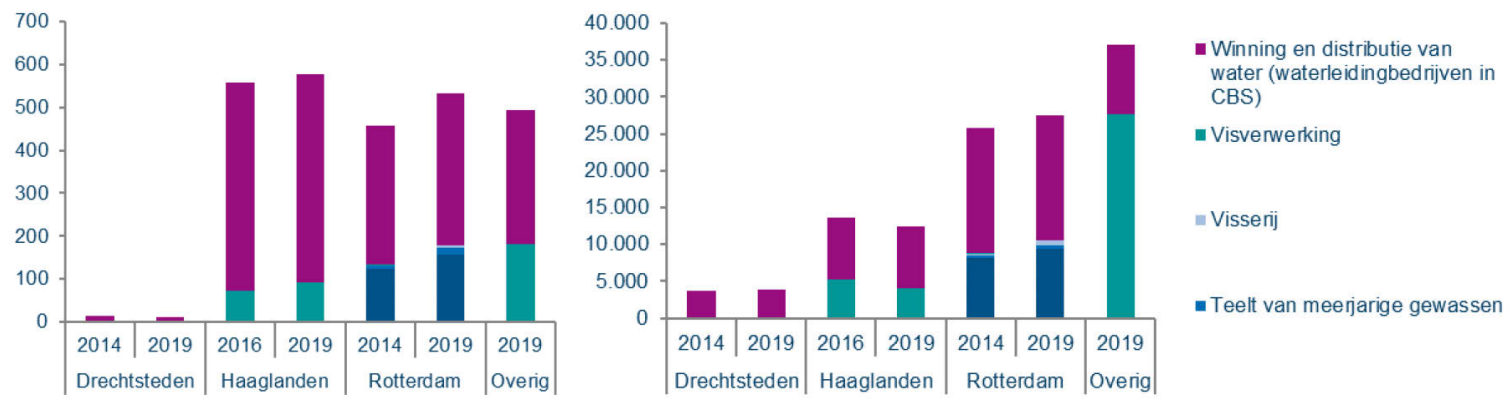

Figuur $5 \quad$ Werkgelegenheid (links) en bruto vloeroppervlak (bvo) (rechts) in de sector Voedsel Bron: LISA (2020); bewerking Ecorys.

\section{Maritiem transport}

Veruit het grootste deel van de werkgelegenheid en het ruimtebeslag van de sector maritiem transport is in de regio Rotterdam (Figuur 6). De sector maritiem transport vertoont over de afgelopen jaren weinig verandering. Zowel wat betreft werkgelegenheid als ruimtebeslag is er weinig verschuiving zichtbaar. De kustgemeenten hebben een verwaarloosbaar aandeel in de sector maritiem transport.

Trends en ontwikkelingen binnen de sector maritiem transport zijn afhankelijk de mate van economische groei, het verloop van de Brexit en andere geopolitieke ontwikkelingen. De krimp van olie- en gaswinning zal zorgen voor een teruggang in transport en onderhoud aan installaties op zee. Dit zal echter door de transitie naar wind op zee grotendeels worden opgevangen. Daarnaast is een toename in cruisevaart en veerdiensten te verwachten door de groei in (kust)recreatie.
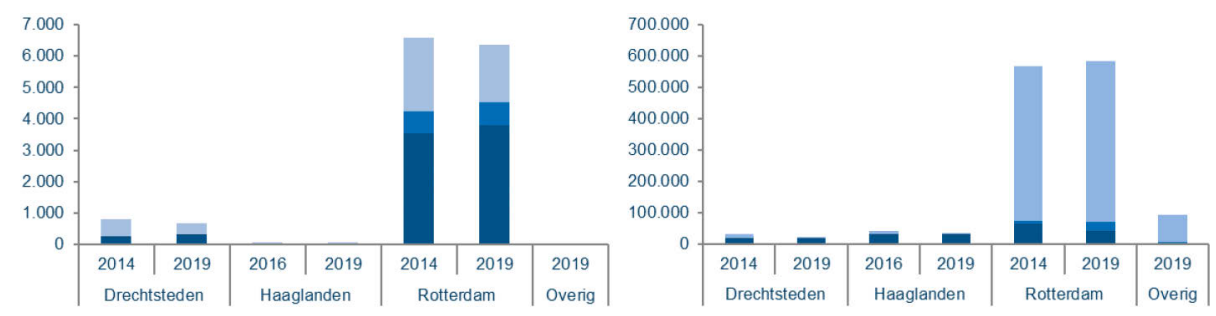

-Zee-en kustvaart (vracht- tank-en Sleepvaart - Zee- en kustvaart (passagiersvant en - Aardolieverwerking

Figuur 6 Werkgelegenheid (links) en brutovloeroppervlak (bvo) (rechts) in de sector Maritiem transport

Bron: LISA (2020); bewerking Ecorys.

\subsection{Toekomstscenario's}

In Figuur 7 is de economische impact (in termen van ontwikkeling van het aantal banen en ontwikkeling van het ruimtebeslag) per scenario zichtbaar. Daarbij zijn per scenario verschillende ontwikkelingen uitgelicht. Per ontwikkeling is aangegeven welke invloed dit heeft op de ontwikkeling van het aantal banen in de sector of op de ontwikkeling van het ruimtebeslag van de sector. Hierbij wordt ingegaan op de richting en sterkte van de ontwikkeling van het aantal banen en het ruimtebeslag. De ontwikkeling gaat in op het nettoresultaat. Wanneer een ontwikkeling tot een nettotoename van het aantal banen of van het ruimtebeslag leidt, wordt dit aangegeven met een (donker) groene kleur. Een nettodaling wordt aangegeven met een (donker) oranje kleur. Wanneer het totale aantal banen ongeveer gelijk blijft (doordat geen ontwikkeling plaatsvindt of er slechts een verschuiving in het type banen plaatsvindt) wordt dit aangegeven met een licht gele kleur. Hierna wordt de impact per scenario verder toegelicht. 
Pragmatisch duurzaam

\section{Duurzame ambitie}

Samen duurzaam Ontwikkeling

Toename recreatie aan kust, wOZ

toerisme en eco-recreatie

Grootte

Banen Bvo

To
aan
do
Toelichting

Olie\& gas uiteput en dets banen

Ca. 7000
vervangen door CCS

Geen verandering in scheepvaart-

bewegingen, havens behoude \begin{tabular}{l}
$+/-\quad \begin{array}{l}\text { Werkgelegenheid blijft nagenoeg gelijk en } \\
\text { deels vervangen door CCS }\end{array}$ \\
\hline
\end{tabular} an kust. Sterke toename ruimtetesestas door uitbreiding recreatieaanbod

1 Toes

\begin{tabular}{|l|l|c|c|}
\hline \multicolumn{1}{|c|}{ Ontwikkeling } & \multicolumn{1}{|c|}{ Grootte } & Banen & Bvo \\
\hline $\begin{array}{l}\text { Toename recreatie aan kusten op } \\
\text { zee, WOZ- } \text { Wn eilanden- en eco- } \\
\text { toerismenemen toe }\end{array}$ & $\begin{array}{l}\text { Ca. } 55.000 \\
\text { banen }\end{array}$ & ++ & ++ \\
\hline Olie\& gas snel onrendabel & $\begin{array}{l}\text { Ca. } 7000 \\
\text { banen }\end{array}$ & -- & -- \\
\hline $\begin{array}{l}\text { Groei en verduurzaming } \\
\text { scheepvaart, grote havens } \\
\text { versterken positiemaar breiden } \\
\text { niet uit }\end{array}$ & $\begin{array}{l}\text { Ca. } 3000 \\
\text { banen }\end{array}$ & + & + \\
\hline $\begin{array}{l}\text { Maximale toename WOZ en CO2 } \\
\text { opslag }\end{array}$ & $\begin{array}{l}\text { Ca. } 100 \\
\text { banen }\end{array}$ & ++ & ++ \\
\hline $\begin{array}{l}\text { Sterke afname traditionelevisserij, } \\
\text { vervangen door aquacultuur }\end{array}$ & $\begin{array}{l}\text { Ca. } 500 \\
\text { banen }\end{array}$ & - & + \\
\hline
\end{tabular}

\section{Toelichting}

ename werkgelegenheid recreatiesector an kust. Sterke toename ruimtebeslag doo Werkgelegenheid olie-en gaswinning verdwijnt. Ruimte komt vrij

$\begin{array}{lll}\text { banen } & + & \begin{array}{l}\text { Weinigverandering in werkgelegenheid } \\ \text { scheepvaartsector en ruimtebeslag. Geen }\end{array}\end{array}$ scheepvaartsector en ruimtebeslag. Gee

Kleine toename WOZ

Ca. 100 veranderingen in logistieke sector

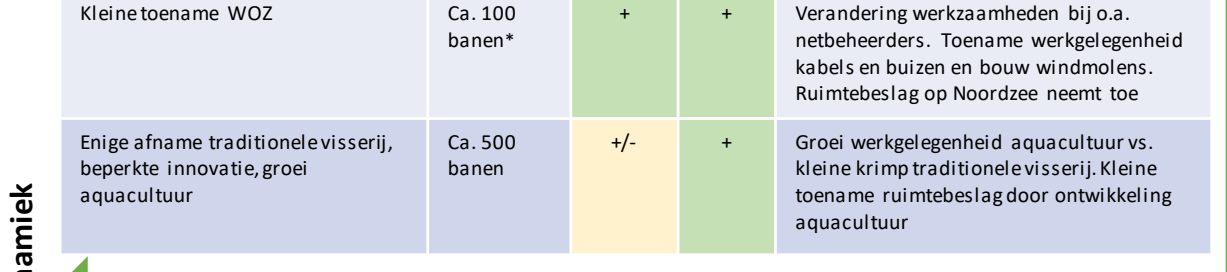
netbeheerders. Toename werkgelegent kabels en buizen en bouw windmolens.
Ruimtebeslag op Noordzee neemt toe

Groei werkgelegenheid aquacultuur vs. aquacultuur \begin{tabular}{|l|l|l} 
vervangen door aquacultuur & banen & $\begin{array}{l}\text { vervangen door minder arbeidsintensieve } \\
\text { aquacultuur. Toename ruimtebeslag door } \\
\text { ontwikkeling aquacultuur }\end{array}$ \\
\hline
\end{tabular}

\section{Langzaam verder}

๘)

\section{Langzaam verde
Ontwikkeling}

geen

Grootte

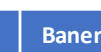

Bvo

Toelichting

Recreatie aan kust neemt af, geen Ca. 55.000 banen

$-\quad$ Licht

Lichte afname werkgelegenhei recreatiesector aan kust. Kleine afname ruimtebeslag

\begin{tabular}{|l|l|l|l|l|}
\hline Olie \& gas uitgeput tot na 2030 & $\begin{array}{l}\text { Ca. } 7000 \\
\text { banen }\end{array}$ & $+/-$ & $+/-$ & $\begin{array}{l}\text { Werkgelegenheid en ruimtebeslag blijven } \\
\text { gelijk }\end{array}$ \\
\hline
\end{tabular}

Kleinegroei en verduurzaming scheepvaart, grote havens

C. $3000 \quad+/ \quad+$ +- $\quad$ Groei werkgelegenheid in

behouden positiemaar breiden niet

uit

scheepvaartsector. Geen uitbreiding werkgelegenheid en ruimtebeslag havens en logistieke sector

\begin{tabular}{|l|l|c|l|l|}
\hline Minimaletoename WOZ & $\begin{array}{l}\text { Ca. } 100 \\
\text { banen }\end{array}$ & $+/-$ & $+/$ & $\begin{array}{l}\text { Weinig verandering in werkgelegenheid. } \\
\text { Minimaal ruimtebeslag op Noordzee }\end{array}$ \\
\hline $\begin{array}{l}\text { Kleineafname traditionele visserij, } \\
\text { visserijbeperkt innovatief, } \\
\text { aquacultuur neemt beperkt toe }\end{array}$ & $\begin{array}{l}\text { Ca. } 500 \\
\text { banen }\end{array}$ & $+/$ & + & $\begin{array}{l}\text { Kleine groei werkgelegenheid aquacultuur } \\
\text { vs. kleine krimp traditionelevisserij. } \\
\text { Beperkte toename ruimtebeslag door } \\
\text { ontwikkeling aquacultuur }\end{array}$ \\
\hline
\end{tabular}

aquacultuur neemt beperkt toe ontwikkeling aquacultuur

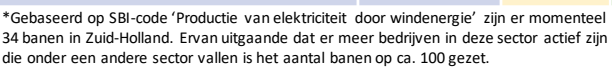

Vaststaand beleid (2015/2030)

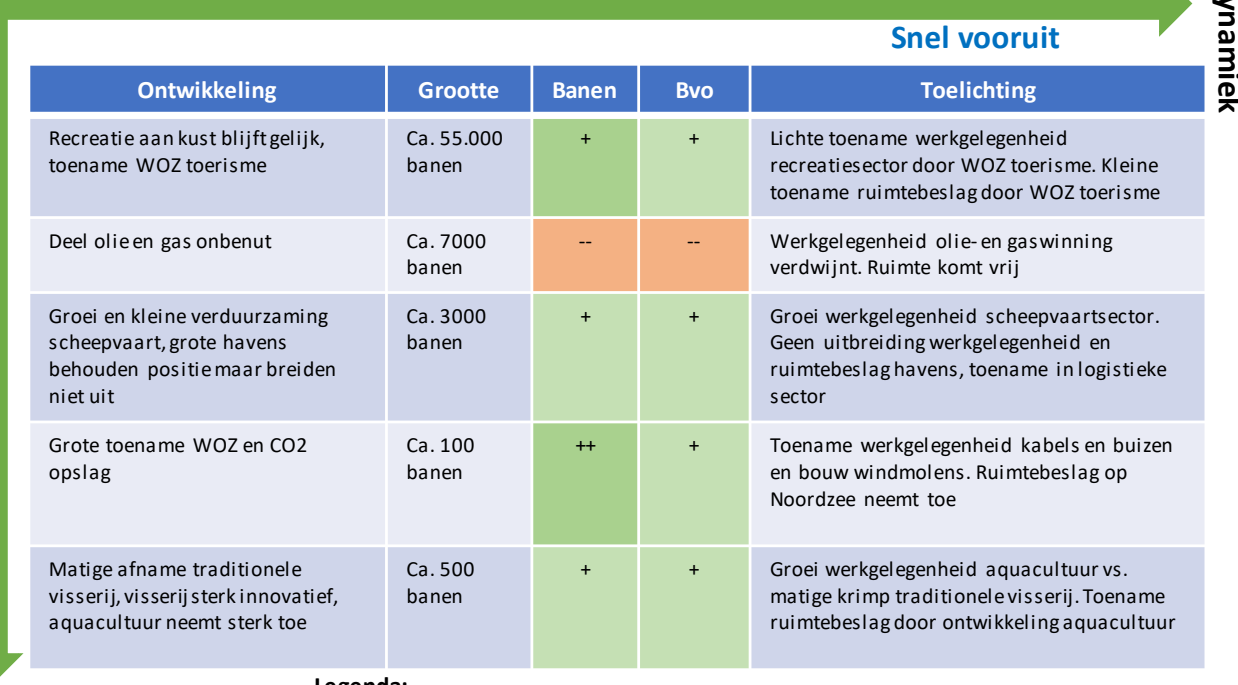

nuitbreiding van havens maar wel ename ruimtedruk en werkgelegenheid in etbeheerders. Toename werkgelegenheid bels en buizen en bouw windmolens. tebeslag op Noordzee neemt sterk toe erke krimp traditionele visserij, wordt

Figuur 7 Economische impacts van de Noordzeescenario's voor 2030/2050, in termen van werkgelegenheid (banen) en brutovloeroppervlak (bvo) 


\subsubsection{Scenario I - Langzaam verder}

In Tabel 2 is de economische impact van het scenario 'Langzaam verder' schematisch weergegeven. Daarna wordt de impact toegelicht.

Tabel 2 Economische impacts van het Noordzee scenario 'Langzaam verder' voor 2030/2050, in termen van werkgelegenheid (banen) en brutovloeroppervlak (bvo)

\begin{tabular}{|c|c|c|c|}
\hline Ontwikkeling & Huidge grootte & Werkgelegenheid (banen) & Ruimtebeslag (bvo) \\
\hline $\begin{array}{l}\text { Recreatie aan kust neemt af, geen } \\
\text { WOZ-toerisme }\end{array}$ & Circa 75.000 banen & - & - \\
\hline Olie \& gas uitgeput tot na 2030 & Circa 7000 banen & $+/-$ & $+/-$ \\
\hline $\begin{array}{l}\text { Kleine groei en verduurzaming } \\
\text { scheepvaart, grote havens } \\
\text { behouden positie maar breiden } \\
\text { niet uit }\end{array}$ & Circa 3000 banen & $+/-$ & $+/-$ \\
\hline Minimale toename WOZ & Circa 100 banen a) & $+/-$ & $+/-$ \\
\hline $\begin{array}{l}\text { Kleine afname traditionele } \\
\text { visserij, visserij beperkt } \\
\text { innovatief, aquacultuur neemt } \\
\text { beperkt toe }\end{array}$ & Circa 1.500 banen & $+/-$ & + \\
\hline
\end{tabular}

a) Gebaseerd op SBI-code 'Productie van elektriciteit door windenergie' zijn er momenteel 34 banen in Zuid-Holland. Ervan uitgaande dat er meer bedrijven in deze sector actief zijn die onder een andere sector vallen is het aantal banen op circa 100 gezet.

- In dit scenario is een lichte afname zichtbaar in de recreatie aan de kust. Dat leidt tot een lichte afname van de hieraan gerelateerde werkgelegenheid en ruimtebeslag. Er is geen toerisme gerelateerd aan ontwikkeling van wind(energie) op zee (WOZ).

- De transitie naar duurzame energiebronnen verloopt in dit scenario langzaam. Olie en gas wordt tot na 2030 uitgeput. Op korte termijn heeft de energietransitie daarmee nauwelijks invloed op de ontwikkeling van de werkgelegenheid en van het ruimtebeslag in de energiesector.

- $\mathrm{Er}$ is een kleine groei en verduurzaming van de scheepvaart. In termen van aantal banen en ruimtebeslag is deze groei verwaarloosbaar. De grote havens behouden de positie, maar breiden niet verder uit. Dit leidt dus niet tot een verschuiving in het aantal banen of in het ruimtebeslag. Er is ook geen doorwerking naar andere sectoren, zoals de logistieke sector.

- $\mathrm{Er}$ is slechts een minimale toename van wind op zee. Dat heeft nauwelijks impact op het aantal banen en op het ruimtebeslag van de sector. Ook de impact op andere sectoren, zoals offshore of toerisme, is verwaarloosbaar.

- Er is een kleine afname zichtbaar in de traditionele visserij. Dat is deels door toedoen van de Brexitafspraken, waarin is afgesproken dat Nederlandse vissers een kwart minder vis mogen vangen dan voorheen. Daar tegenover staat een beperkte stijging van aquacultuur. Al met al blijft het aantal banen hiermee stabiel. Wel is aquacultuur relatief ruimte-intensiever dan de visserij, waarmee het totale ruimtebeslag van de sector beperkt toeneemt. 


\subsubsection{Scenario II - Pragmatisch duurzaam}

In Tabel 3 is de economische impact van het scenario 'Pragmatisch duurzaam' schematisch weergegeven. Daarna wordt de impact toegelicht.

Tabel 3 Economische impacts van het Noordzee scenario 'Pragmatisch duurzaam' voor 2030/2050, in termen van werkgelegenheid (banen) en bruto vloeroppervlak (bvo)

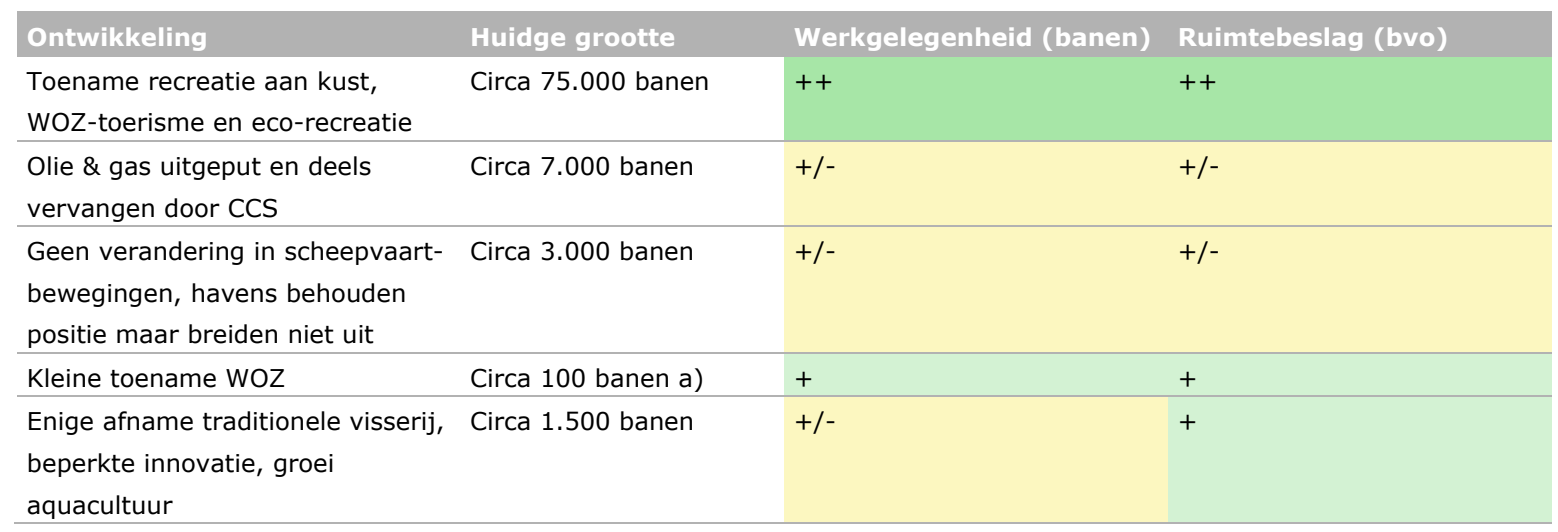

a) Gebaseerd op SBI-code 'Productie van elektriciteit door windenergie' zijn er momenteel 34 banen in Zuid-Holland. Ervan uitgaande dat er meer bedrijven in deze sector actief zijn die onder een andere sector vallen is het aantal banen op circa 100 gezet.

- In dit scenario is een toename van recreatie aan de kust zichtbaar. Daarbij is toerisme gerelateerd aan wind op zee (WOZ) en ecotoerisme in opkomst. De ontwikkelingen leiden tot een sterke groei van het aantal banen en het ruimtebeslag van de recreatiesector in Zuid-Holland.

- De transitie naar duurzame energiebronnen verloopt in dit scenario langzaam. Olie en gas wordt uitgeput en deels vervangen door carbon-capture \& storage (CCS). Op korte termijn heeft de energietransitie daarmee nauwelijks invloed op de ontwikkeling van de werkgelegenheid en van het ruimtebeslag in de energiesector.

- $\mathrm{Er}$ is een geen verandering zichtbaar in de scheepvaartbewegingen. Er is dus geen impact met betrekking tot het aantal banen en het ruimtebeslag van de scheepvaart. Ook havens behouden de positie, maar breiden niet verder uit. Dit leidt dus niet tot een verschuiving in het aantal banen of in het ruimtebeslag. Er is ook geen doorwerking naar andere sectoren, zoals de logistieke sector.

- $\mathrm{Er}$ is slechts een kleine toename van wind op zee. Dat heeft een lichte toename van het aantal banen en het ruimtebeslag van de sector tot gevolg. Door doorwerking is er ook een lichte toename zichtbaar in andere sectoren, zoals offshore of toerisme.

- $\mathrm{Er}$ is een kleine afname zichtbaar in de traditionele visserij, deels door toedoen van de gemaakte Brexit-afspraken. Daar tegenover staat een beperkte stijging van aquacultuur. Al met al blijft het aantal banen hiermee stabiel. Wel is aquacultuur relatief ruimte-intensiever dan de visserij, waarmee het totale ruimtebeslag van de sector beperkt toeneemt. 


\subsubsection{Scenario III - Snel vooruit}

In Tabel 4 is de economische impact van het scenario 'Snel vooruit' schematisch weergegeven. Daarna wordt de impact toegelicht.

Tabel 4 Economische impacts van het Noordzee scenario 'Snel vooruit' voor 2030/2050, in termen van werkgelegenheid (banen) en bruto vloeroppervlak (bvo)

\begin{tabular}{|c|c|c|c|}
\hline Ontwikkeling & Huidge grootte & Werkgelegenheid (banen) & Ruimtebeslag (bvo) \\
\hline $\begin{array}{l}\text { Recreatie aan kust blijft gelijk, } \\
\text { toename WOZ-toerisme }\end{array}$ & Circa 75.000 banen & + & + \\
\hline $\begin{array}{l}\text { Groei en kleine verduurzaming } \\
\text { scheepvaart, grote havens } \\
\text { behouden positie maar breiden } \\
\text { niet uit }\end{array}$ & Circa 3.000 banen & + & + \\
\hline $\begin{array}{l}\text { Grote toename } \mathrm{WOZ} \text { en } \mathrm{CO}_{2-} \\
\text { opslag }\end{array}$ & Circa 100 banen a) & ++ & + \\
\hline $\begin{array}{l}\text { Matige afname traditionele } \\
\text { visserij, visserij sterk innovatief, } \\
\text { aquacultuur neemt sterk toe }\end{array}$ & Circa 1.500 banen & + & + \\
\hline
\end{tabular}

a) Gebaseerd op SBI-code 'Productie van elektriciteit door windenergie' zijn er momenteel 34 banen in Zuid-Holland. Ervan uitgaande dat er meer bedrijven in deze sector actief zijn die onder een andere sector vallen is het aantal banen op circa 100 gezet.

- In dit scenario is een toename van toerisme gerelateerd aan wind op zee (WOZ) zichtbaar. Overige recreatie aan de kust blijft gelijk. De ontwikkeling leidt tot een toename van het aantal banen en het ruimtebeslag van de recreatiesector in Zuid-Holland.

- De transitie naar duurzame energiebronnen verloopt in dit scenario snel. De winning en het gebruik van olie en gas wordt gestopt, waarmee olie en gas deels onbenut blijft. Dit heeft een sterke daling van de werkgelegenheid en het ruimtebeslag in de energiesector tot gevolg. Dit werkt ook door in andere sectoren, aangezien ook de bijproducten van olie en gas komen te vervallen. Er komt dus veel ruimte beschikbaar.

- Er is een groei zichtbaar in de scheepvaart. Dit heeft een lichte toename van de werkgelegenheid en het ruimtebeslag tot gevolg. In de havens is geen verandering zichtbaar. Wel is een stijging van de werkgelegenheid en het ruimtebeslag in de logistieke sector zichtbaar.

- $\mathrm{Er}$ is een grote toename van wind op zee. Daarnaast wordt $\mathrm{CO}_{2}$-opslag ontwikkeld. Dat heeft een sterke toename van het aantal banen en het ruimtebeslag van de sector tot gevolg. Door doorwerking is er ook een lichte toename zichtbaar in andere sectoren, zoals offshore, aanleg van kabels en buizen en toerisme.

- Er is een matige afname zichtbaar in de traditionele visserij, deels door toedoen van de gemaakte Brexit-afspraken. Daar tegenover staat een sterke stijging van aquacultuur. Netto heeft dit een lichte toename van de werkgelegenheid tot gevolg. Aangezien aquacultuur relatief ruimteintensiever is dan de visserij, neemt ook het totale ruimtebeslag van de sector toe maar niet op grote schaal. Zoals in paragraaf 2.1.1. beschreven, is de ontwikkeling van grootschalige (zoute) aquacultuur in Nederland relatief onrendabel. Het is daardoor niet aannemelijk dat deze sector zich op grote schaal in Nederland uitbreidt. 


\subsubsection{Scenario IV - Samen duurzaam}

In Tabel 5 is de economische impact van het scenario 'Samen duurzaam' schematisch weergegeven. Daarna wordt de impact toegelicht.

Tabel 5 Economische impacts van het Noordzeescenario 'Samen duurzaam' voor 2030/2050, in termen van werkgelegenheid (banen) en bruto vloeroppervlak (bvo)

\begin{tabular}{|c|c|c|c|}
\hline Ontwikkeling & Huidge grootte & Werkgelegenheid (banen) & Ruimtebeslag (bvo) \\
\hline $\begin{array}{l}\text { Toename recreatie aan kust en op } \\
\text { zee, WOZ- en eilanden- en eco- } \\
\text { toerisme nemen toe }\end{array}$ & Circa 75.000 banen & ++ & ++ \\
\hline Olie \& gas snel onrendabel & Circa 7.000 banen & -- & -- \\
\hline $\begin{array}{l}\text { Groei en verduurzaming } \\
\text { scheepvaart, grote havens } \\
\text { versterken positie maar breiden } \\
\text { niet uit }\end{array}$ & Circa 3.000 banen & + & + \\
\hline $\begin{array}{l}\text { Maximale toename } \mathrm{WOZ} \text { en } \mathrm{CO}_{2}- \\
\text { opslag }\end{array}$ & Circa 100 banen a) & ++ & ++ \\
\hline $\begin{array}{l}\text { Sterke afname traditionele } \\
\text { visserij, vervangen door } \\
\text { aquacultuur }\end{array}$ & Circa 1.500 banen & - & + \\
\hline
\end{tabular}

a) Gebaseerd op SBI-code 'Productie van elektriciteit door windenergie' zijn er momenteel 34 banen in Zuid-Holland. Ervan uitgaande dat er meer bedrijven in deze sector actief zijn die onder een andere sector vallen is het aantal banen op circa 100 gezet.

- In dit scenario is een toename van toerisme gerelateerd aan wind op zee (WOZ) en ecotoerisme zichtbaar. Ook overige recreatie aan de kust neemt toe. De ontwikkelingen leiden tot een sterke toename van het aantal banen en het ruimtebeslag van de recreatiesector in Zuid-Holland.

- De transitie naar duurzame energiebronnen verloopt in dit scenario snel. Door ontwikkelingen is de winning en het gebruik van olie en gas snel onrendabel. Hierdoor blijft olie en gas deels onbenut. Dit heeft een sterke daling van de werkgelegenheid en het ruimtebeslag in de energiesector tot gevolg. Dit werkt ook door in andere sectoren.

- Er is een groei zichtbaar in de scheepvaart. Dit heeft een lichte toename van de werkgelegenheid en het ruimtebeslag tot gevolg. In de havens is geen verandering zichtbaar. Wel is een stijging van de werkgelegenheid en het ruimtebeslag in de logistieke sector zichtbaar.

- Er is een maximale toename van wind op zee. Daarnaast wordt $\mathrm{CO}_{2}$-opslag ontwikkeld. Dat heeft een sterke toename van het aantal banen en het ruimtebeslag van de sector tot gevolg. Door doorwerking is er ook een lichte toename zichtbaar in andere sectoren, zoals offshore, aanleg van kabels en buizen en toerisme.

- $\mathrm{Er}$ is een sterke afname zichtbaar in de traditionele visserij, versterkt door de gemaakte Brexitafspraken. Dit wordt vervangen door aquacultuur. Netto heeft dit een lichte daling van de werkgelegenheid tot gevolg. Aangezien aquacultuur relatief ruimte-intensiever is dan de visserij, neemt het totale ruimtebeslag van de sector wel toe. 


\section{$4 \quad$ Ruimte}

Dit hoofdstuk brengt in beeld de huidige ruimtelijke situatie (Sectie 4.1) en de verwachte ruimtelijke impacts van de vier scenario's (Sectie 4.2) voor de Provincie Zuid-Holland. De ruimtelijke situatie is beschreven per gebied (Zee- en windmolenvelden; Dynamische kust; De havens) op basis van een landschapssysteemanalyse (zie Bijlage 1: B1.4).

\subsection{Huidige situatie}

Vanuit een ruimtelijk perspectief zijn er drie gebieden te onderscheiden waar trends, impacts en kansen kunnen worden beschreven en beleidsopties benoemd kunnen worden: de zee- en windmolenvelden (Sectie 4.1.1), de dynamische kust (Sectie 4.1.2) en, tot slot, de havens (Sectie 4.1.3). Voor deze drie gebieden beschrijven we in deze sectie de huidige situatie.

\subsubsection{Zee- en windmolenvelden}

De zee- en windmolenvelden omvatten het gebied buiten het kustfundament tot de rand van het Nederlands Continentaal Plat (NCP; zie Figuur 8). Belangrijke gebruiksfuncties in dit gebied zijn scheepvaart, visserij, olie- en gaswinning, zandwinning, wind op zee (WOZ) en natuur. 


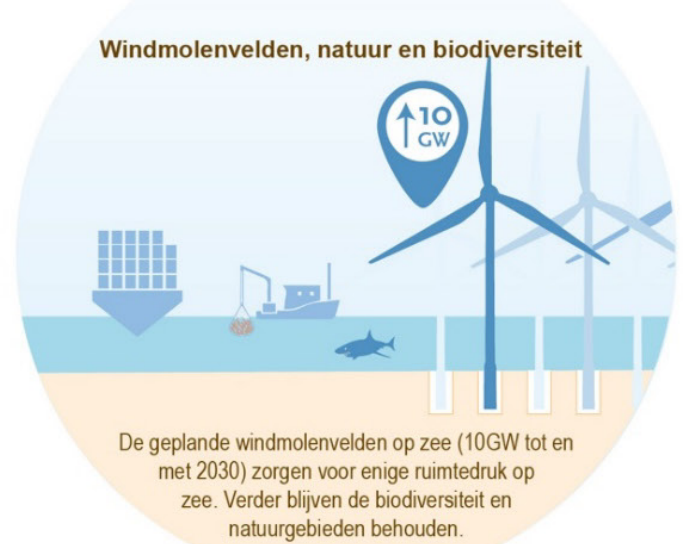

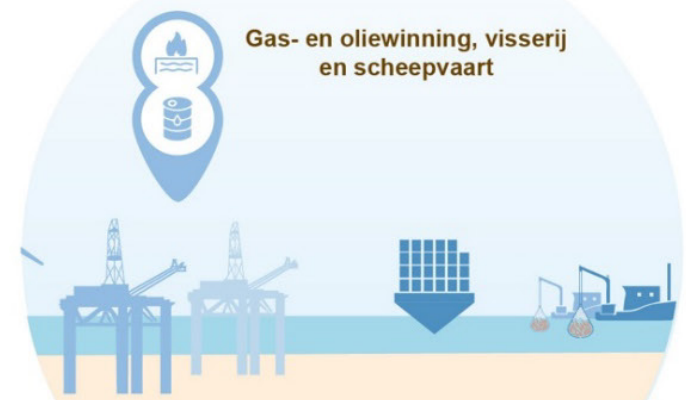

Gas- en oliewinning vindt plaats op zee. Verder wordt er op de traditionele manier gevist en is er (enige) ruimte voor

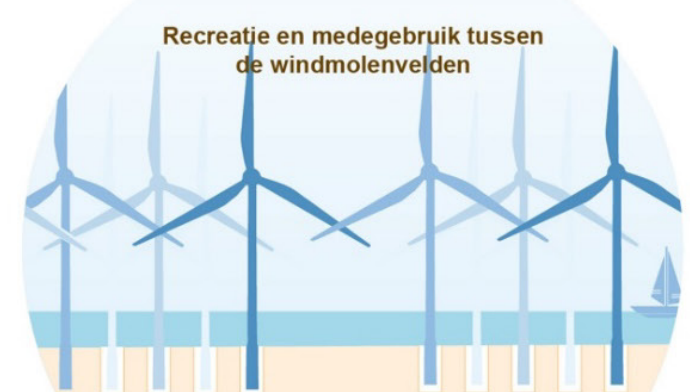

Tussen de windmolenvelden is er geen aquacultur. Recreatie vindt plaa

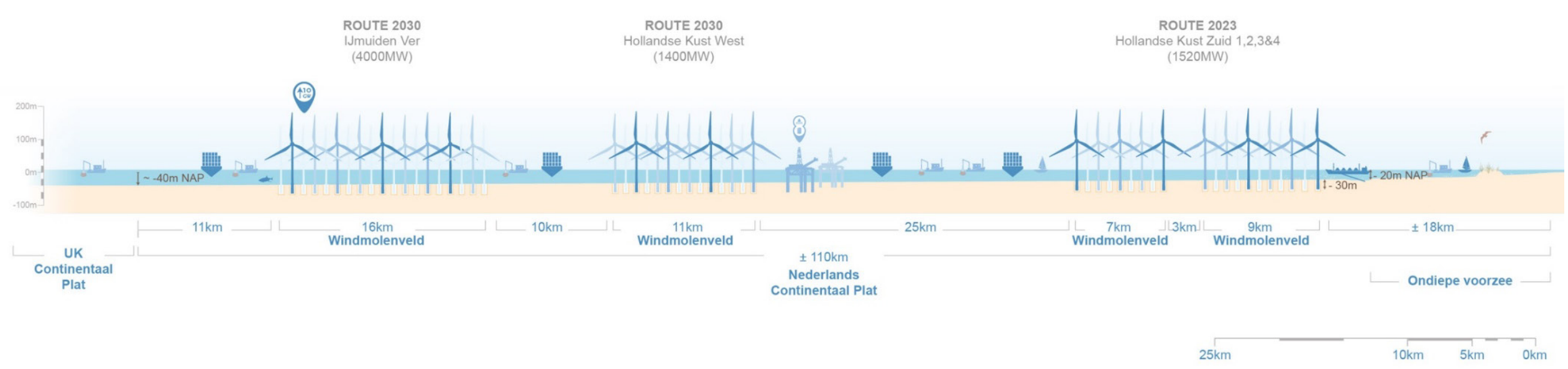

Figur $8 \quad$ Huidige situatie zee- en windmolenvelden 


\subsubsection{Energievoorziening vanuit de Noordzee}

De Noordzee is belangrijk voor onze energievoorziening. Ook in het ruimtegebruik is de transitie naar duurzame energie in de huidige situatie al merkbaar. Waar tot voor kort op de Noordzee alleen meer verspreide objecten werden gebouwd, zoals platforms voor olie- en gaswinning en kabels en leidingen (zie Figuur 9), worden nu hele velden in de zee geoccupeerd. Om windmolens te plaatsen worden flinke delen van de zee geordend in bouwblokken waar windmolens komen, en daartussen komen corridors voor scheepvaart (zie Figuur 11). In de huidige situatie gaat het daarbij nog niet om de hele zee, maar al wel om aanzienlijke gebieden. Met name de ondiepere delen van de zee worden momenteel benut (zie Figuur 10). En als je een uitsnede voor de Zuid-Hollandse kust maakt die doorloopt tot Groot-Brittannië, dan is nu al een groot deel van de zee verdeeld (zie Figuur 8).
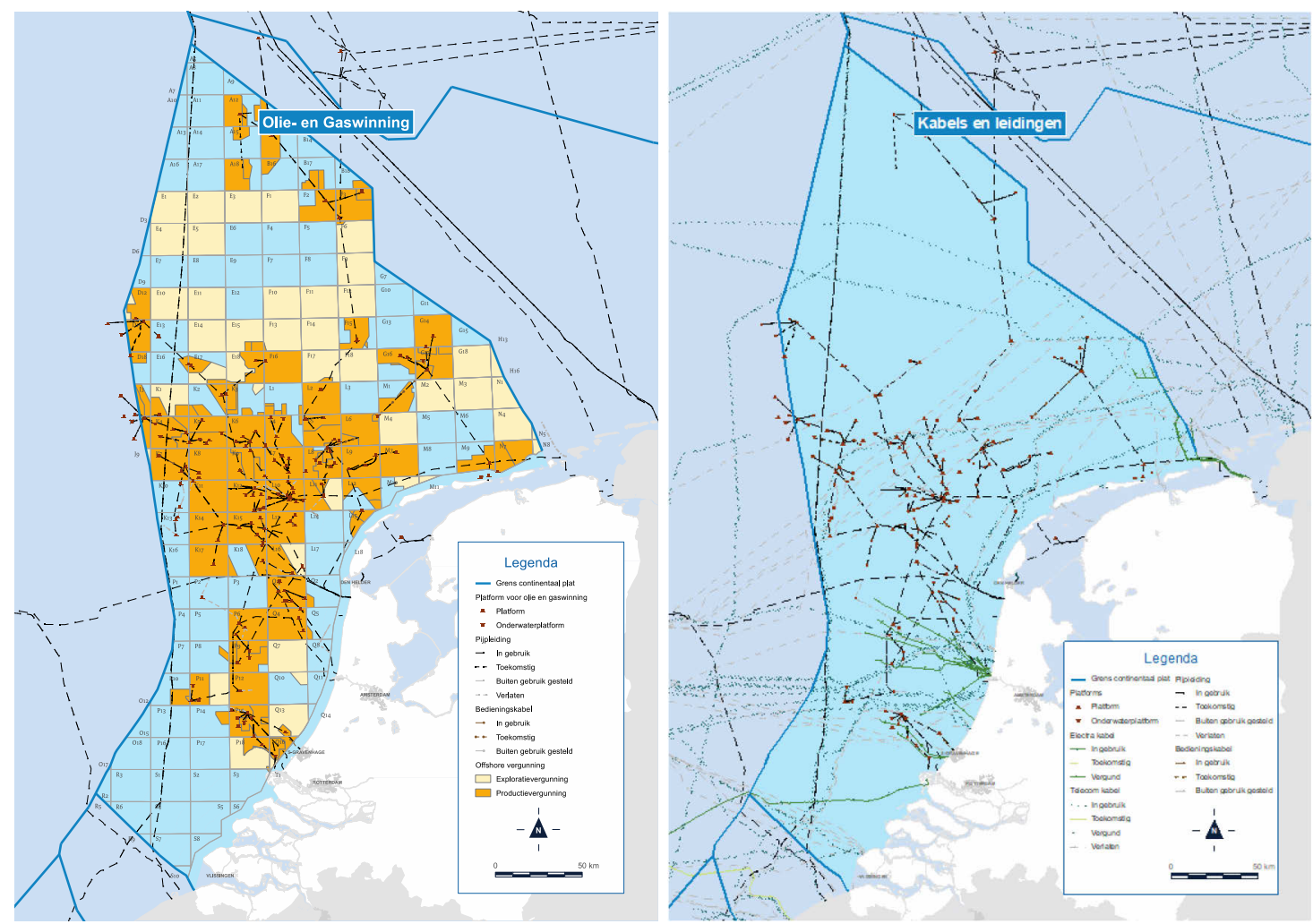

Figuur 9 Olie- en gaswinning (links) en kabels en leidingen (rechts)

Bron: Noordzeeloket (2021c, 2021a).
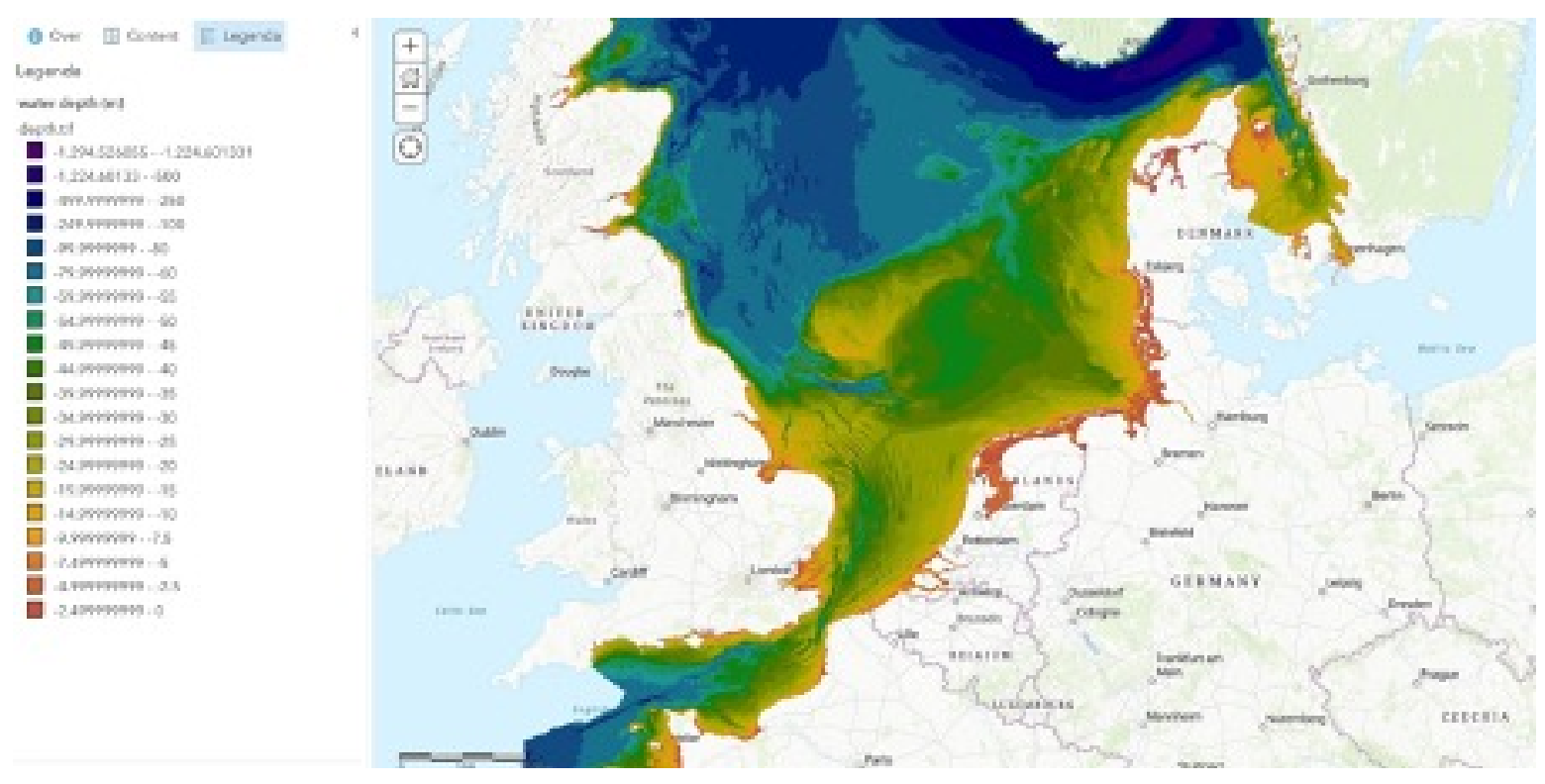

Figuur 10 Waterdiepte van de Noordzee Bron: Reijden et al. (2018). 

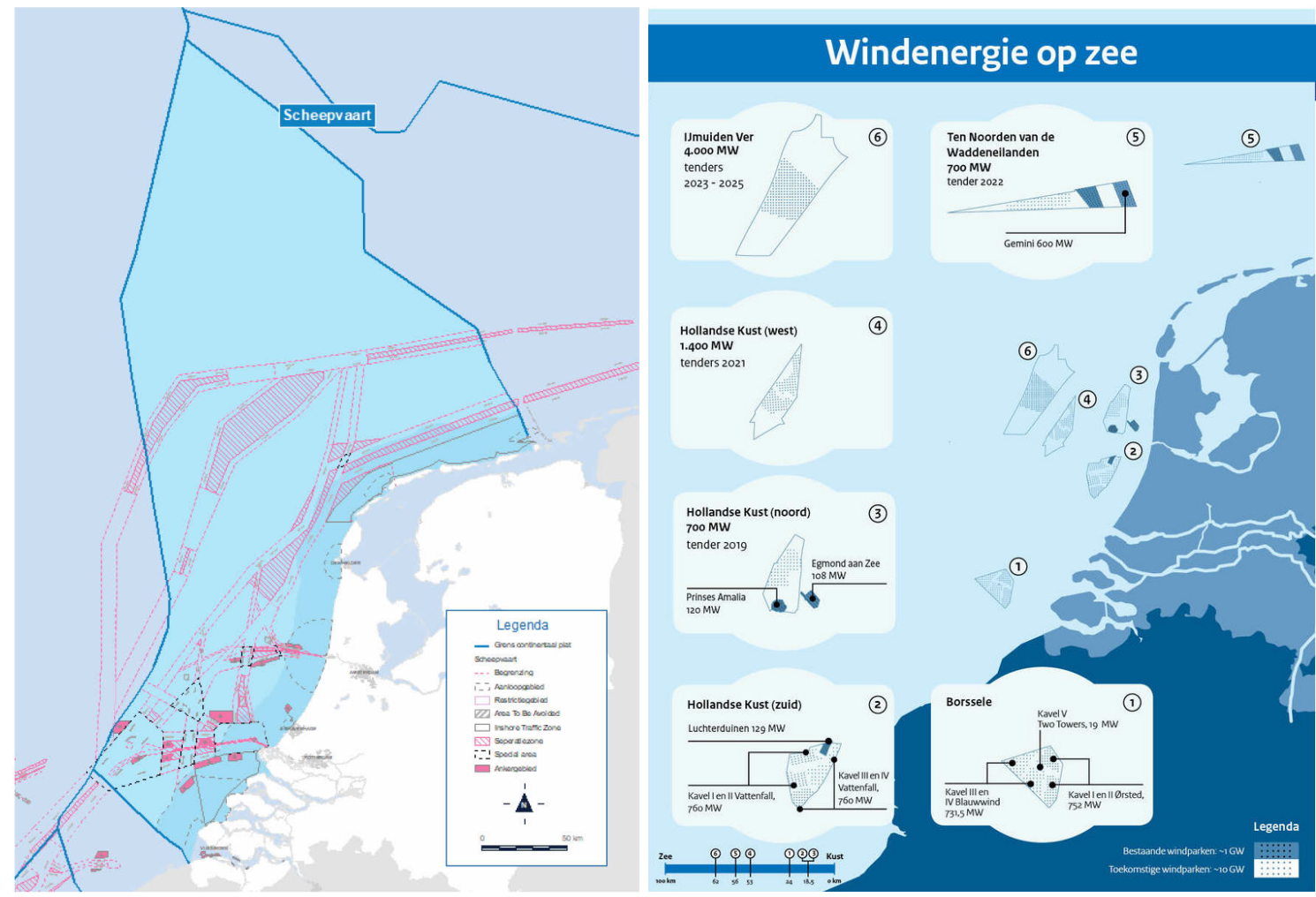

Figuur 11 Scheepvaart (links) en windenergie op zee (rechts) Bron: Noordzeeloket (2021e, 2021g).

\subsubsection{Nutriëntenschaarste en visserij}

De rivieren die in de Noordzee uitkomen zijn in de afgelopen decennia schoner geworden. Rioolwaterzuivering is standaard en in de landbouw is het beleid gericht op vermindering van de uitspoeling van nutriënten. Daardoor is er een beperkte nutriëntenomvang op de Noordzee. Vissers geven aan dat de aangroei van vis minder is geworden door deze nutriëntenschaarste.
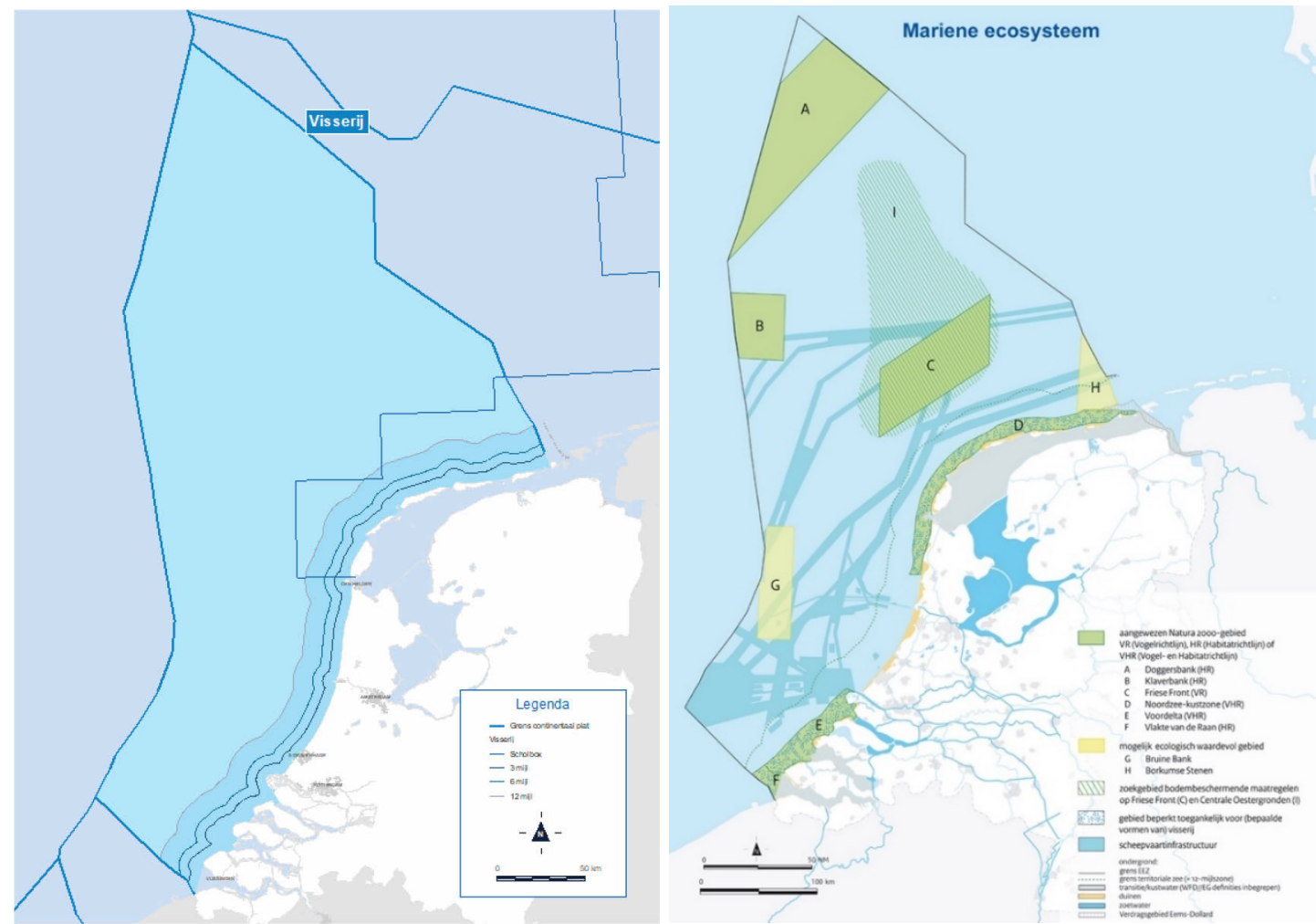

Figuur 12 Visserijzones (links) en mariene ecosysteem (rechts) Bron: Noordzeeloket (2021f, 2021b). 
Voor visserij op de Noordzee geldt Europese regelgeving. Hierin is vastgesteld welke landen in welke zones op welke soorten mogen vissen (zie Figuur 12). Deze zones zijn aangegeven in miles vanaf de Nederlandse kust. Over het algemeen geldt dat visserij niet is toegestaan binnen windturbineparken, binnen een zone van 500 meter rond mijnbouwplatforms, in scheepvaartroutes, aanloopgebieden en clearways, boven gronden waar veel munitie ligt en in bepaalde delen van Natura 2000-gebieden (zie Figuur 12). Deze gebieden beslaan momenteel nog geen groot deel van de Noordzee, maar zijn de laatste jaren onder andere door de energietransitie wel toegenomen.

\subsubsection{Biodiversiteit}

Het gebruik van de Noordzee heeft impact op de biodiversiteit. Wind op zee (WOZ) is nog een relatief nieuwe ruimtevrager. Wat de effecten zijn van windmolenparken op het ecosysteem van de Noordzee, wordt momenteel onderzocht in het Windenergie op zee ecologische programma (WOZEP). Dit zorgt voor betere kennis van het ecosysteem en betere onderbouwde voorschriften voor windmolenparken. Momenteel wordt er aanvullend onderzoek gedaan om beter te begrijpen wanneer effecten zich voordoen en hoe groot de effecten zijn. Er zijn studies die aangeven dat wind op zee mogelijkheden biedt voor vissen en benthos, maar een negatieve impact heeft op zeezoogdieren en vogels (Jongbloed et al., 2020; Roebeling et al., 2021).

\subsubsection{Dynamische kust}

De dynamische kust beslaat het kustfundament (-20m NAP in zee tot de binnenzijde van de duinen) en een aanzet van het binnenland (zie Figuur 13). Belangrijke gebruiksfuncties in dit gebied zijn scheepvaart (passage naar havens), recreatieve scheepvaart, visserij, recreatie en natuur.

Uitdagingen rond kustveiligheid, de omgang met onzekerheden en het meervoudig gebruik van de kust, staan gedefinieerd in de Nationale Visie Kust (I\&M, 2013). In deze visie is de koers gericht op het verbinden van opgaven met maatwerk per locatie en vindt samenwerking tussen partijen plaats via het Kustpact (I\&W, 2017). Het zwaartepunt ligt bij veiligheid en de relatie tussen veiligheid en ruimtegebruik. Op korte termijn wordt het beleid 'dynamisch handhaven' voortgezet, met suppletiezand op het strand en/of de onderwateroever. Op de middellange termijn zijn, als gevolg van klimaatverandering, sterkere en bredere waterkeringen nodig op plekken van smalle duinen en dijken (met reservering van ruimte en oog voor collectieve waarden). 


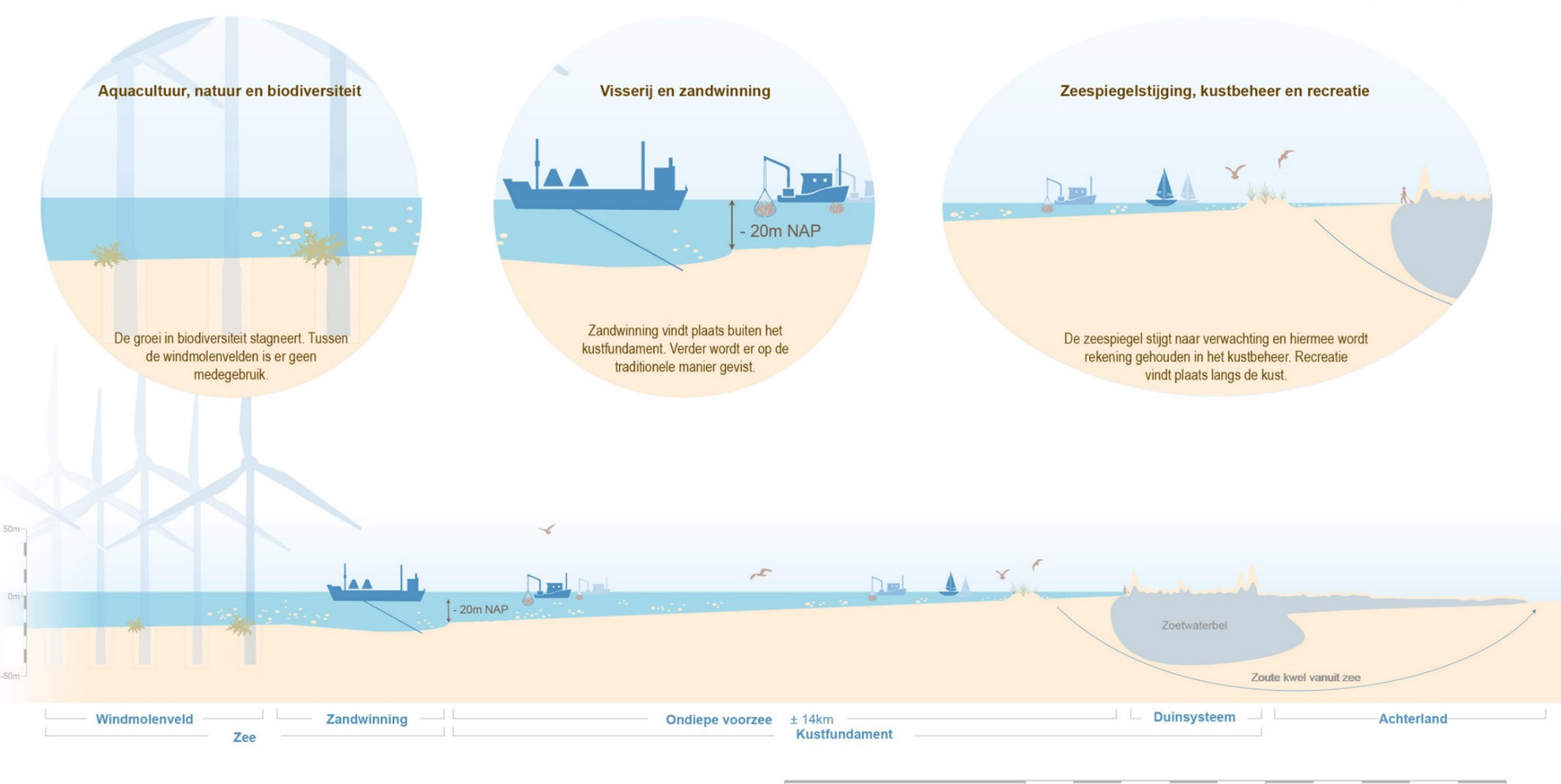

Figuur 13 Huidige situatie dynamische kust 


\subsubsection{Natuurlijke kustbogen}

De morfologie van de kust is complex maar op een bepaald niveau ook door leken te begrijpen. Als je een groot water zoals de Waddenzee of de Haringvliet afdamt, gedeeltelijk of geheel, dan vermindert dit de in- en uitgaande eb- en vloedwaterstroom vanuit zee. Het effect is dat het gebied aan de zeezijde een nieuw evenwicht zoekt met minder diepe geulen en veel meer ondiepe delen door sedimentatie.

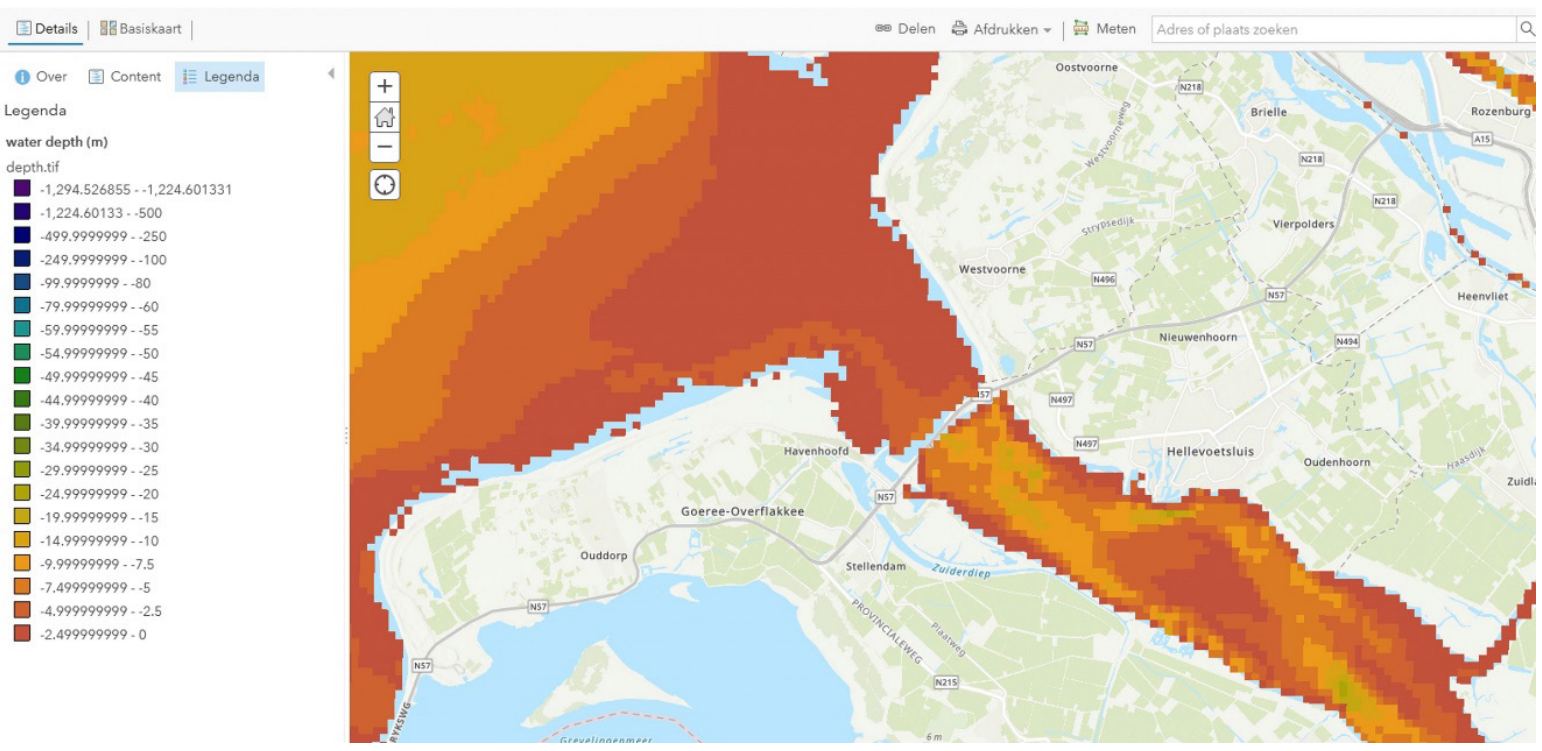

Figuur 14 Waterdiepte bij de Haringvlietdam

Bron: Reijden et al. (2018).

Als gevolg daarvan is na het realiseren van de deltawerken een enorme sedimentatie gestart in de delta die inmiddels tot een ondiepe kust heeft geleid en grote sedimentatie in de Oosterschelde. Een van de kenmerkende beelden is dat het afgesloten water achter de dam veel dieper is dan het deel voor de dam, zoals in de Haringvlietmonding (zie Figuur 14). In de Grevelingen is dit effect nog veel sterker omdat deze volledig afgesloten is.

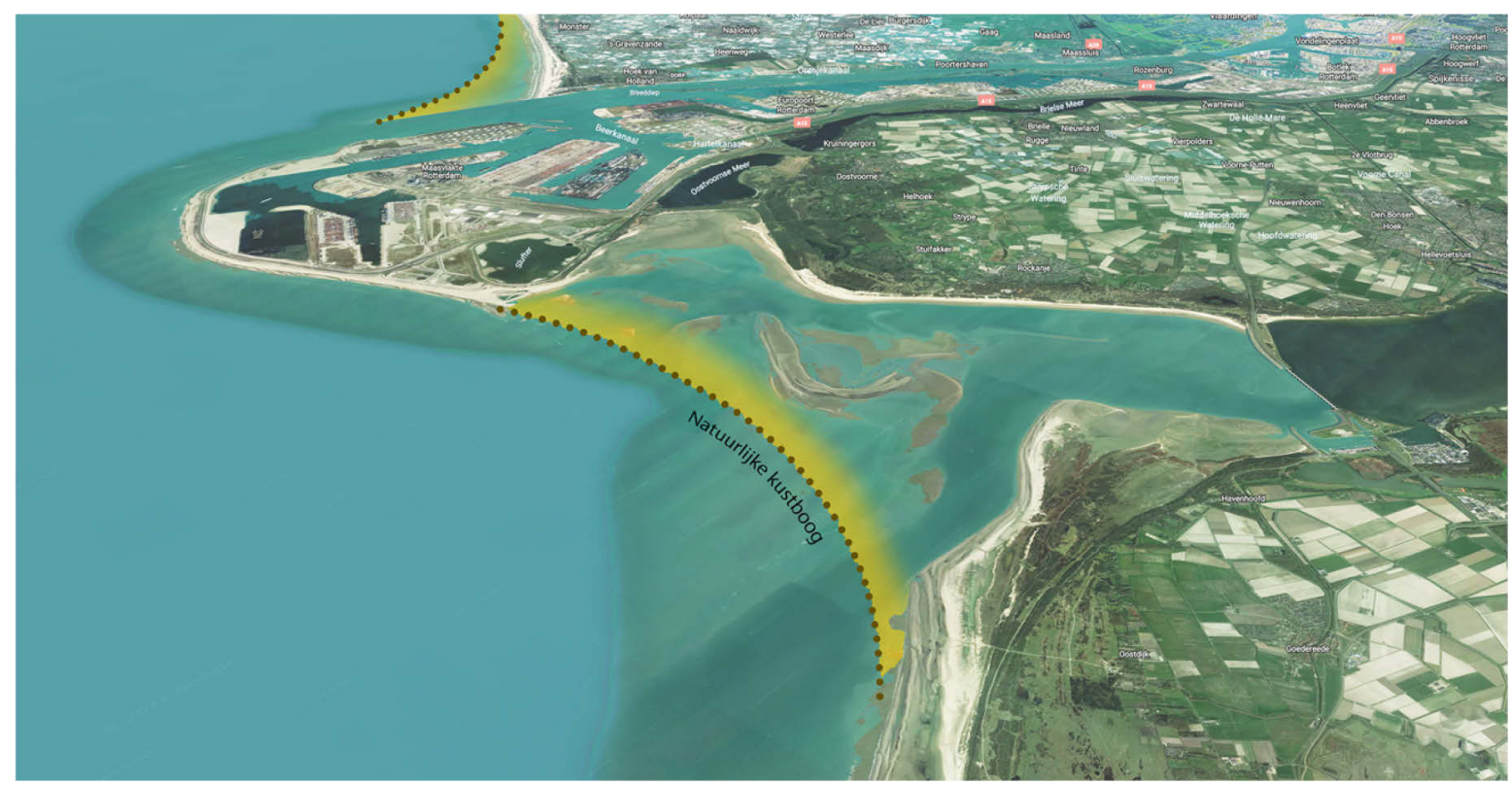

Figuur 15 Natuurlijke kustboog 
Als je een harde constructie ver de zee inbouwt, zoals bij Rotterdam (Maasvlakte 2), dan heeft de zee de neiging een natuurlijke kustboog te vormen vanuit het ene vaste punt naar het andere (zie Figuur 15). In de Voordelta zijn beide processen (sedimentatie en vorming van natuurlijke kustbogen) aan de gang en al vrij ver gevorderd. Daardoor kan er in de komende decennia een stabiele situatie volgens de natuurlijk kustboog ontstaan. Ook aan de noordzijde van de haven bij Hoek van Holland gebeurt dit. Voorwaarde is wel dat er ten zuiden van Rotterdam geen nieuwe grote ingrepen in de kust komen die sediment af zouden vangen van de zandrivier.

\subsubsection{Geven en nemen van de zandrivier}

De kust(her)vorming is voor een gedeelte het gevolg van lokale verplaatsing van sediment en wordt structureel gevoed door de zandrivier. Netto is er langs de kust een stroming van zuid naar noord. In die stroom wordt zand meegenomen, de zandrivier. Vanuit het zuiden wordt er steeds zand toegevoegd aan de zandrivier. Onderweg langs de Nederlandse kust wordt er zand afgezet en opgenomen.
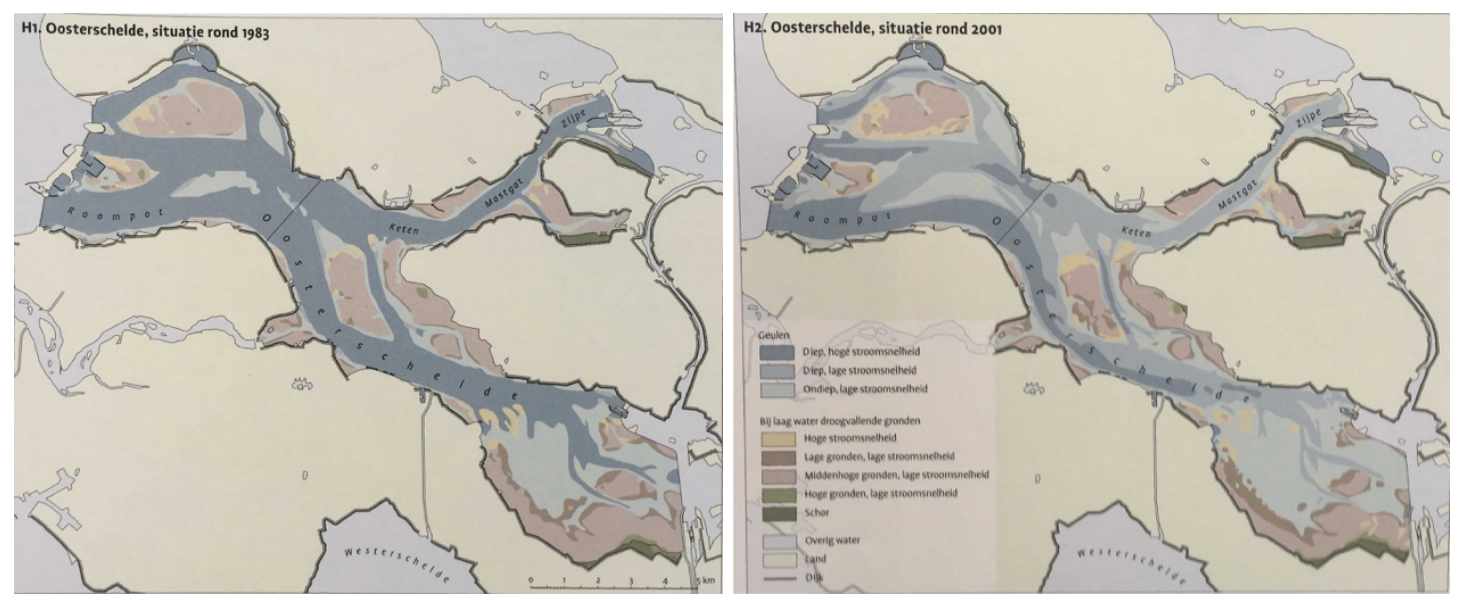

Figuur 16 Effect van de Oosterscheldewerken Bron: De Bosatlas (2007).

De genoemde kustwerkzaamheden leiden tot grote inbreuken op de stroom. Door de Oosterscheldewerken is de instroomopening daar sterk verkleind (maar wel gebleven) waardoor er decennia van sedimentatie is opgestart waarin heel veel zand uit de zandrivier is opgenomen (zie Figuur 16).

De vooruitgeschoven havenconstructies van Rotterdam en IJmuiden zijn ook voor de zandrivier belangrijk. Wat je daar ziet is dat ten zuiden van deze constructies meer zand wordt afgezet dan afgeslagen en ten noorden meer wordt afgeslagen dan afgezet (op enige afstand van de havenmonden). Om een indruk te geven van de resultaten van dit proces: bij IJmuiden is de kustlijn langs de havenmond aan de zuidzijde ongeveer 1,5 km zeewaarts opgeschoven na de aanleg van het Noordzeekanaal (zie Figuur 17). 

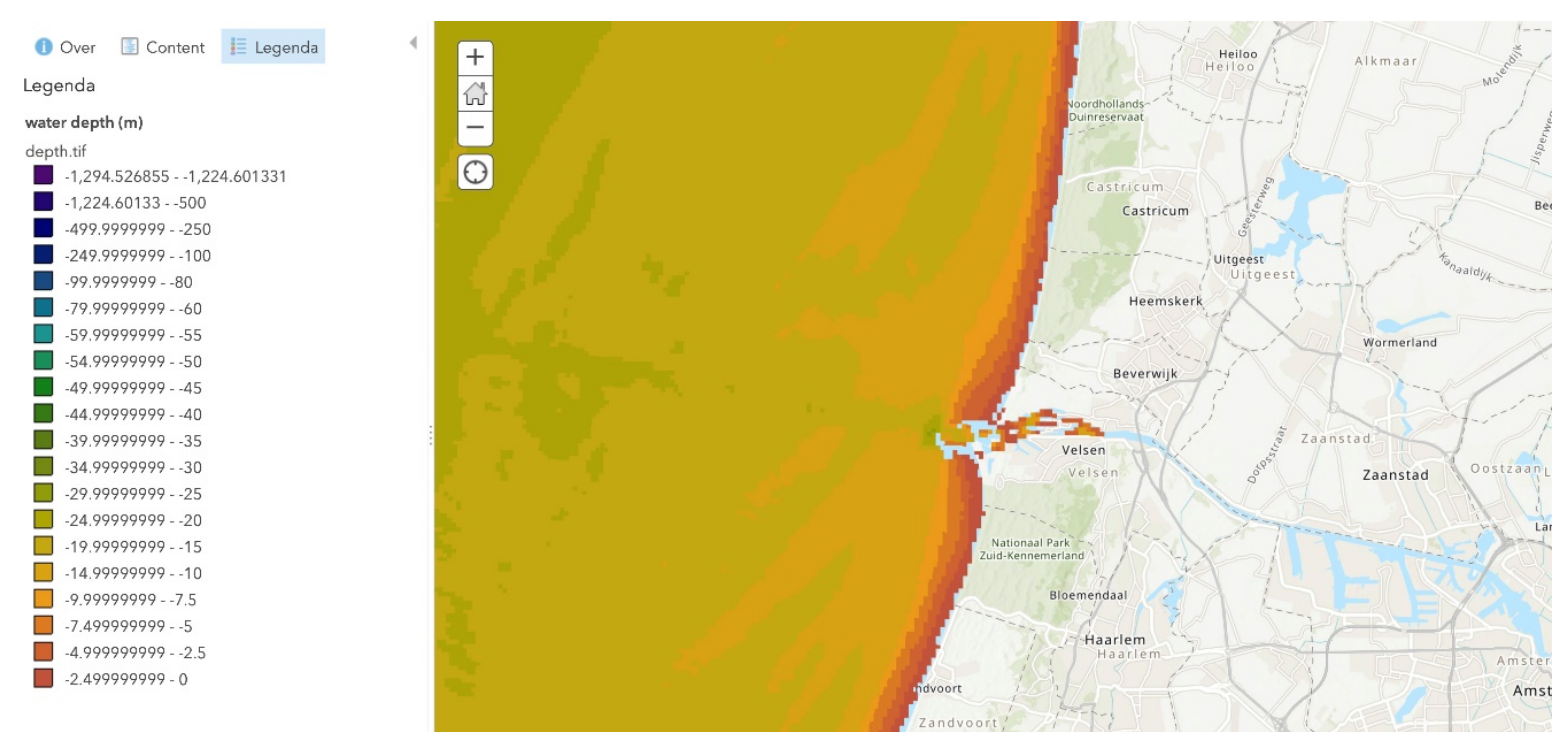

Figuur 17 Impact op de sedimentatie door de aanleg van het Noordzeekanaal Bron: Reijden et al. (2018).

Uiteindelijk beland het zand van de zandrivier dat het noorden van de kust haalt in de Waddenzee. Daar is immers de grootste verstoring aangebracht door de aanleg van de Afsluitdijk. Maar de zandlading is zo klein geworden dat er zorgen zijn of de sedimentatie daar de zeespiegelstijging wel bij kan houden. Na 2050 kan de zeespiegel mogelijk snel en sterk stijgen. Projecties voor 2100 geven een bandbreedte aan voor zeespiegelstijging tot 2 meter bij $2^{\circ} \mathrm{C}$ temperatuurstijging en tot 3 meter bij $4^{\circ} \mathrm{C}$ temperatuurstijging (Deltares, 2019).

\subsubsection{Zandmotor}

Een zandmotor wordt ingezet om de evenwichtssituatie van de zandrivier te versnellen. De zandmotor ligt op een plek waar meer zand wordt meegenomen in de zandrivier dan wordt afgezet. Dit versterkt het effect van de motor. Door de aanleg van Maasvlakte 2 wordt ten noorden meer zand afgeslagen dan afgezet. Daarom is ten noorden van de Maasvlakte de Zuid-Hollandse zandmotor gepositioneerd die zand toevoegt aan de zandrivier. Het zand van de zandmotor zal wellicht grotendeels voor IJmuiden terechtkomen en daar het herstel van een evenwichtssituatie versnellen. Als aan de zuidzijde van de Maasvlakte de evenwichtssituatie is bereikt wordt er bij Hoek van Holland veel meer zand aangevoerd door de zandrivier en zal er bij de zandmotor meer dan nu ook zand worden afgezet.

De zandmotor is op zichzelf ook een verstoring van de natuurlijke kustlijn. Op termijn zal een genuanceerder 'spel met zandmotoren' mogelijk worden. Erosie en afzetting op de zandmotor komen immers dichter bij elkaar te liggen. De Zuid-Hollandse kust blijft nog vele jaren een laboratorium voor de ontwikkeling van kennis over kustmorfologie. Het actief en doelgericht interveniëren in die morfologie is een wereldproduct. Daarom is het ook aantrekkelijk zo nu en dan eens wat te proberen en verder te ontwikkelen als er aanleiding voor is en dit veilig kan.

\subsubsection{Dynamisch kustbeheer}

De gerichte aanplant van helm om bewust duinen te vormen is iets van de laatste eeuw. Zand blijft hangen tussen helmplanten waardoor het duin groeit en door de netwerkwortels waait het ook niet zomaar weg. Tientallen jaren is er bewust met de aanplant gestuurd op een 'zanddijk' direct achter het strand met een omvang die voldoet aan de veiligheidseisen (genoeg zand om na een maatgevende storm nog zo'n storm aan te kunnen). Het resultaat daarvan is op de hoogtekaart goed te zien: 'de zanddijk' achter het strand is uitermate gelijkvormig (zie Figuur 18). 


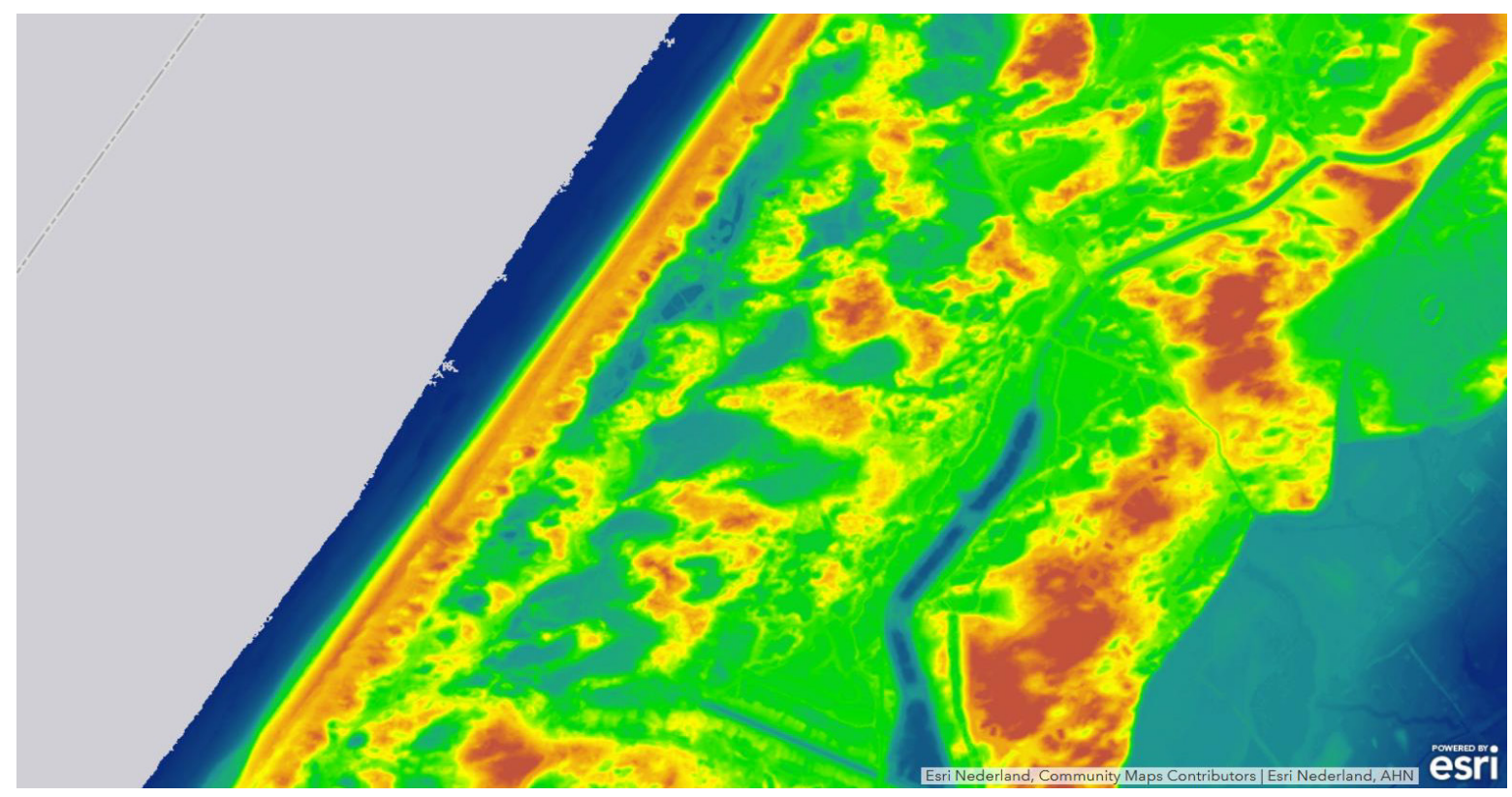

Figuur 18 Hoogtekaart van de duinen Bron: AHN3 (2020).

Het natuurlijke duinbeeld is heel anders. Zoals op de bijgaande serie van schilderijen te zien is, is er vooral een veel onregelmatiger duinbeeld in de eerste zone achter het strand (zie Figuur 19).
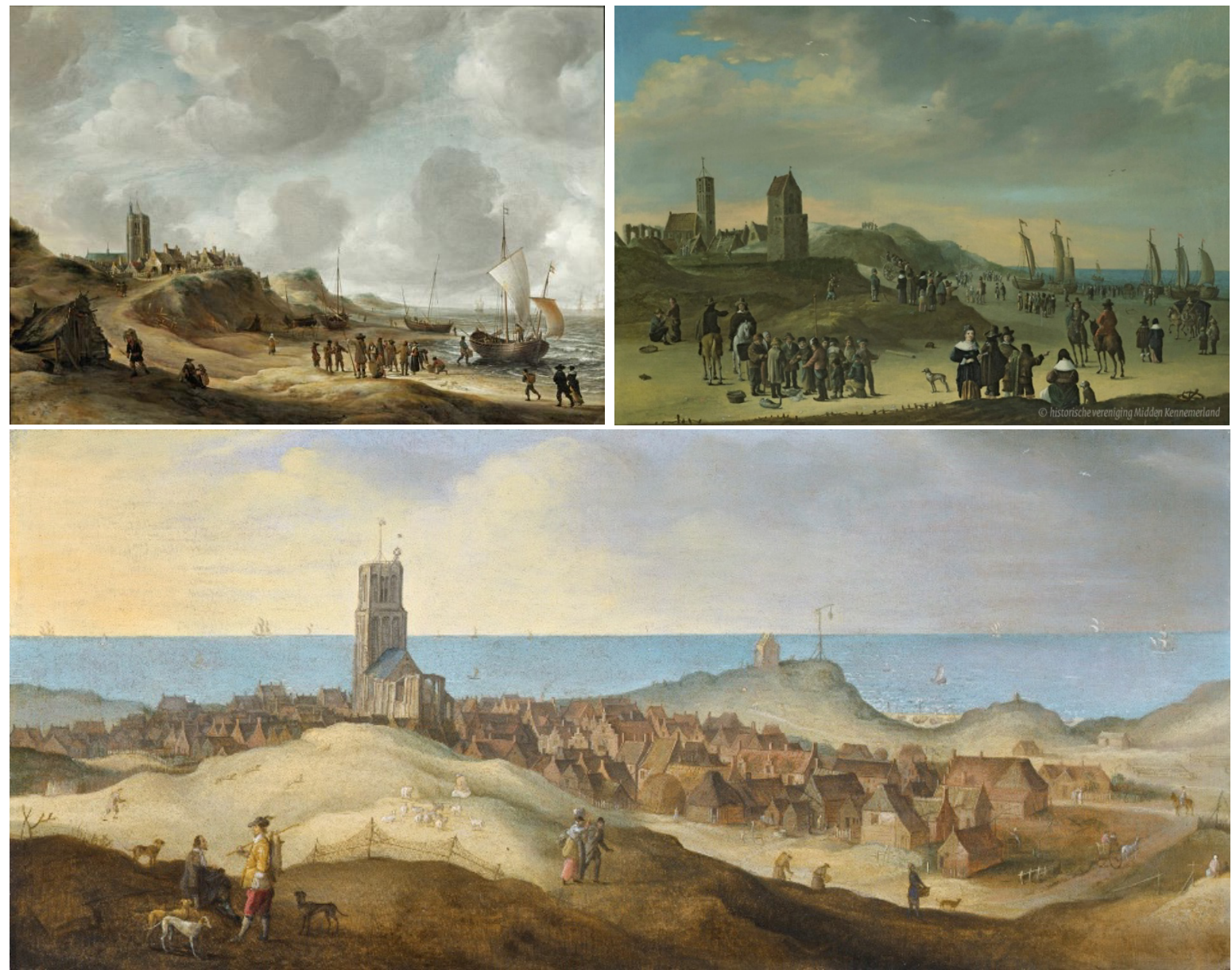

Figuur 19 Visafslag op het strand van Egmond aan Zee (linksboven; Johannes Lingelbach, 16371666); Strand bij Wijk aan Zee (rechtsboven; Cornelis Beelt, 1670); Zicht op Egmond aan Zee (onder; Claes Jacobsz van der Heck, vermoedelijk na 1635) 
Dynamisch zeereepbeheer brengt de natuurlijke duindynamiek terug in de eerste duinzone (met behoud van de veiligheid). In testlocaties (bijvoorbeeld Texel) worden er ingrijpende processen opgestart, zoals waterpartijen die in open verbinding met de zee staan.

\subsubsection{Functies aan de kust}

Een belangrijk moment in de keuze voor het gebruik van de kust was het Kustpact (I\&W, 2017), waarin overheden, natuurorganisaties, de recreatiesector en drinkwaterbedrijven de verschillende waarden van de kust uitleggen en aangeven hoe ze samen de toekomst van de kust vormgeven. Hierin werd, onder andere, bepaald dat verdere bebouwing van de kust werd gestopt. Daarmee ligt de hoofdrichting van het gebruik van de kust vast, en werden overigens jarenlange beleidslijnen gecontinueerd. Op dit moment wordt ook actief gestuurd op het niet laten toenemen van het recreatief totaalgebruik van de duinen en het strand (zie Figuur 20).
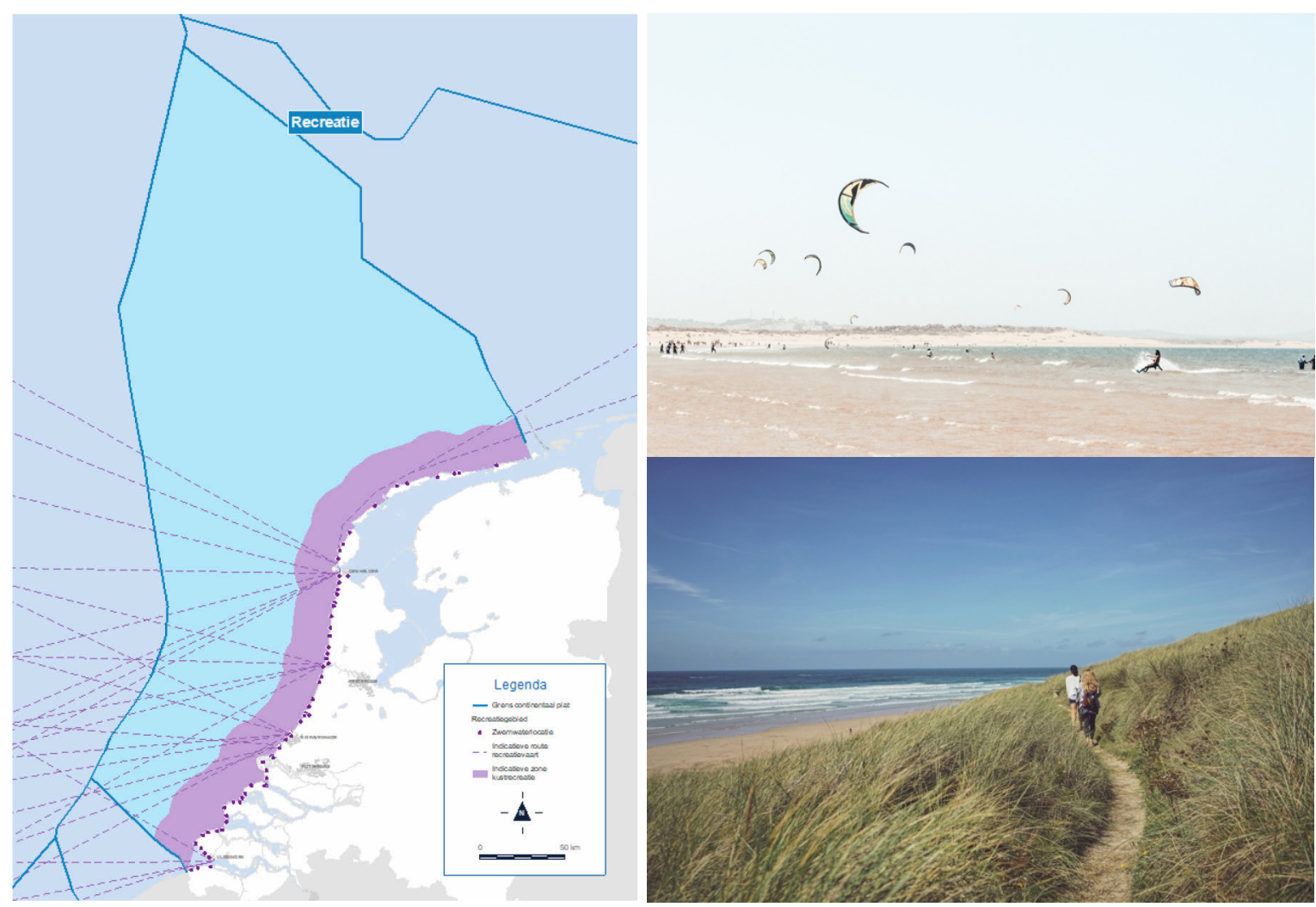

Figuur 20 Recreatie locaties (links; bron: Noordzeeloket, 2021d) en mogelijkheden voor waterrecreatie en wandelen in de duinen (rechts; bron: Unsplash, 2021)

\subsubsection{Naturgebieden}

Grote delen van de duinen en de Voordelta zijn aangewezen als Natuurnetwerk Nederland of Natura 2000 (zie Figuur 21). Door de restricties die er in deze natuurgebieden gelden is er aan de kust een duidelijk onderscheid in ruimte voor intensieve recreatie en ruimte voor natuur. In grote delen van de natuurgebieden kan op een extensieve wijze worden gerecreëerd (zie Figuur 20). 


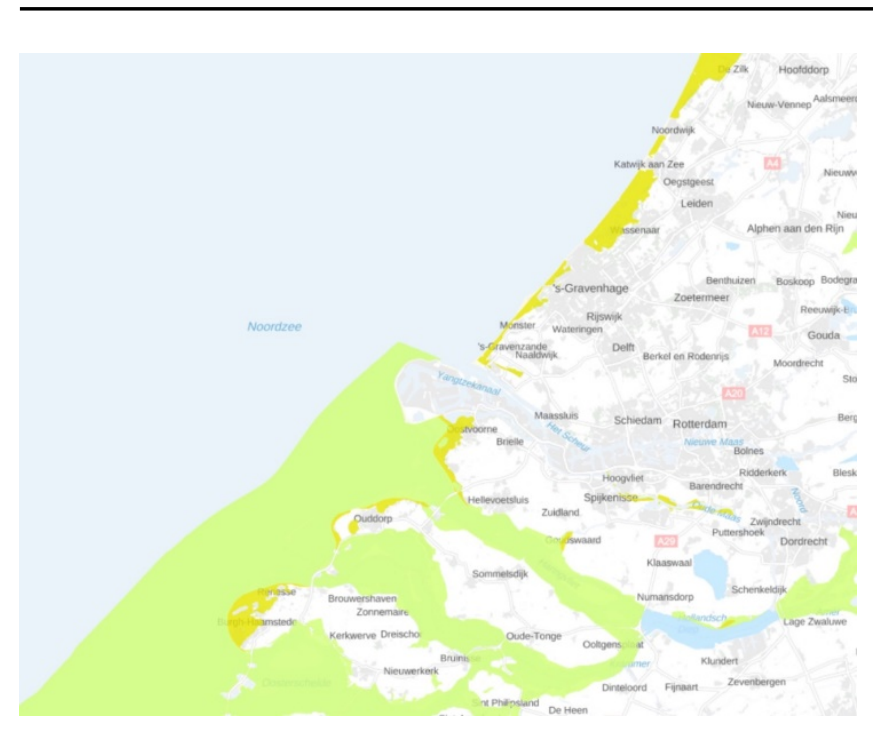

Figuur 21 Aanduiding Natura 2000-gebieden

Bron: Atlas Leefomgeving (2021).

In de Europese Kaderrichtlijn maritieme ruimtelijke planning (Richtlijn 2014/89/EU) ${ }^{7}$ wordt aangegeven dat in het planningsproces rekening moet worden gehouden met de wisselwerkingen tussen land en zee, en dat de samenwerking tussen de lidstaten moet worden bevorderd. Zo zijn naast de natuurgebieden op land, de Voordelta een Natura 2000-gebied dat een gedeelte van het Zuid-Hollandse kustfundament beschermt op EU-niveau. Door de bescherming van de bodem is, echter, de boomkorvisserij op platvis sterk afgenomen.

\subsubsection{Havens}

De havens hebben met name betrekking op het havengebied van Rotterdam (zie Figuur 22). Momenteel is de haven een punt voor opslag en overslag van goederen die via de zee worden aangevoerd en verder worden getransporteerd naar het achterland. Daarnaast is er een deel van de haven ingericht voor industrie, voornamelijk voor olie- en gasverwerking.

\footnotetext{
7 https://eur-lex.europa.eu/eli/dir/2014/89
} 


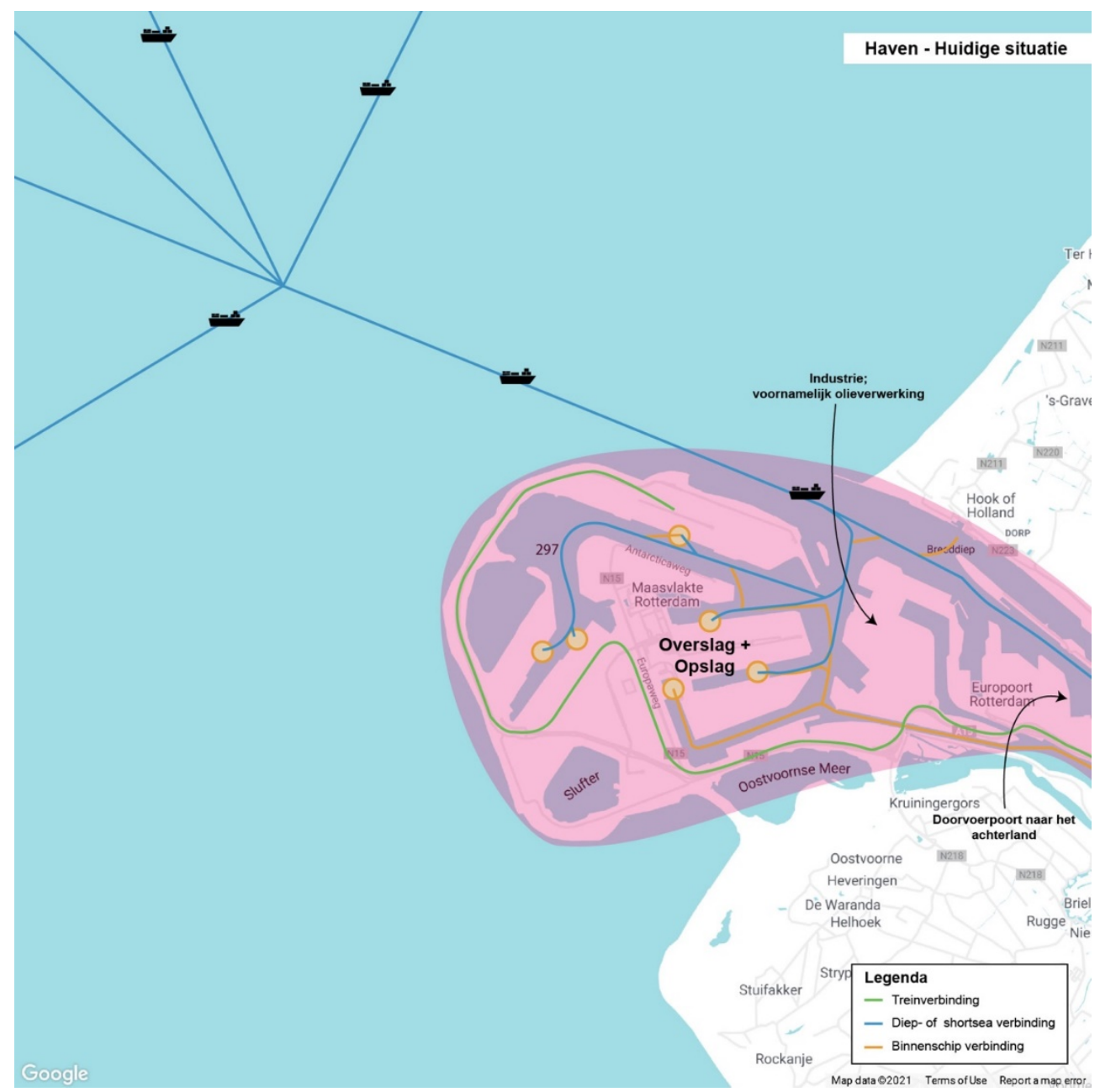

Figuur 22 Huidige situatie bij de Haven van Rotterdam

De Haven van Rotterdam volgt een patroon waarin uitbreidingen altijd in de richting van de zee hebben plaatsgevonden. De laatste twee uitbreidingen (Maasvlakte en Maasvlakte 2) zijn zelfs aangelegd voorbij de natuurlijke kustlijn. Hierdoor heeft de haven een prominente locatie aan zee.

\subsection{Toekomst scenario's}

Ongeacht het scenario is er in het zuidelijk deel van de Noordzee al veel ruimte geoccupeerd door windmolenvelden op zee (Figuur 8). Afhankelijk van het scenario zal deze ruimtevrager sneller of minder snel nog grotere delen van de Noordzee gaan occuperen. Deze ontwikkeling zal eerst plaatsvinden in ondiepe locaties dicht bij de kust (zie EZK, 2018). Ongeacht het scenario speelt dat met de transitie naar duurzame energie extra aandacht uit moet gaan naar aanlandingspunten van elektriciteit. Het aantal en de capaciteit bepaalt wat er mogelijk is wat betreft windenergie op zee.

De ruimte tussen de windturbines heeft potentie om gebruikt te worden voor alternatieve activiteiten. Door welke functies en op welke schaal deze ruimte in gebruik genomen zal worden verschilt per scenario. Denk hierbij aan voedselproductie, natuurontwikkeling, offshore waterstofproductie en bedrijventerreinen op zee. Het is aannemelijk dat aqua-/maricultuur (zeewier en schaal- en schelpdieren), passieve visserij, zonne-energie, recreatie en, mogelijk, natuur zich zullen ontwikkelen tot geschikte functies voor medegebruik binnen een windmolenveld. De schaal waarop dit zal gebeuren hangt af van een aantal verschillen tussen de scenario's, maar daarnaast zal ook het nutriëntenbeheer bepalend zijn voor de schaal waarop dit zich zal kunnen ontwikkelen. Omdat we niet verwachten dat we de zee op grote schaal gaan bemesten, lijkt het waarschijnlijker dat er in de windmolenvelden eerder kwaliteitsproductie dan bulkproductie zal plaatsvinden. 
Afhankelijk van de mate van zeespiegelstijging, is het de vraag of de zandrivier (en de Zandmotor) in de nabije toekomst kunnen zorgen voor een stabiele situatie volgens de natuurlijke kustboog. Bij nieuwe ingrepen in de kustlijn moet er ook rekening worden gehouden met de effecten die dit heeft op de zandrivier en het verplaatsen van sediment. Omdat de ruimte voor natuur en recreatie aan de kust vast staat zal het met name per scenario verschillen hoe intensief die ruimte wordt gebruikt.

Bij een toename van bedrijventerreinen (wind op zee; $\mathrm{CO}_{2}$-opslag; medegebruiksactiviteiten), energieproductie (elektriciteit; waterstof) en voedselproductie (vis; zeewier) op zee zal er ook meer ruimte nodig zijn voor opslag (aanvoer; afvoer), verwerking, gebruik en overslag in de havens. Alles wat op zee nodig is moet worden aangevoerd en alles wat op zee wordt geproduceerd zal een keer aan land komen, vervoerd moeten worden en/of verwerkt worden (zie Figuur 23).

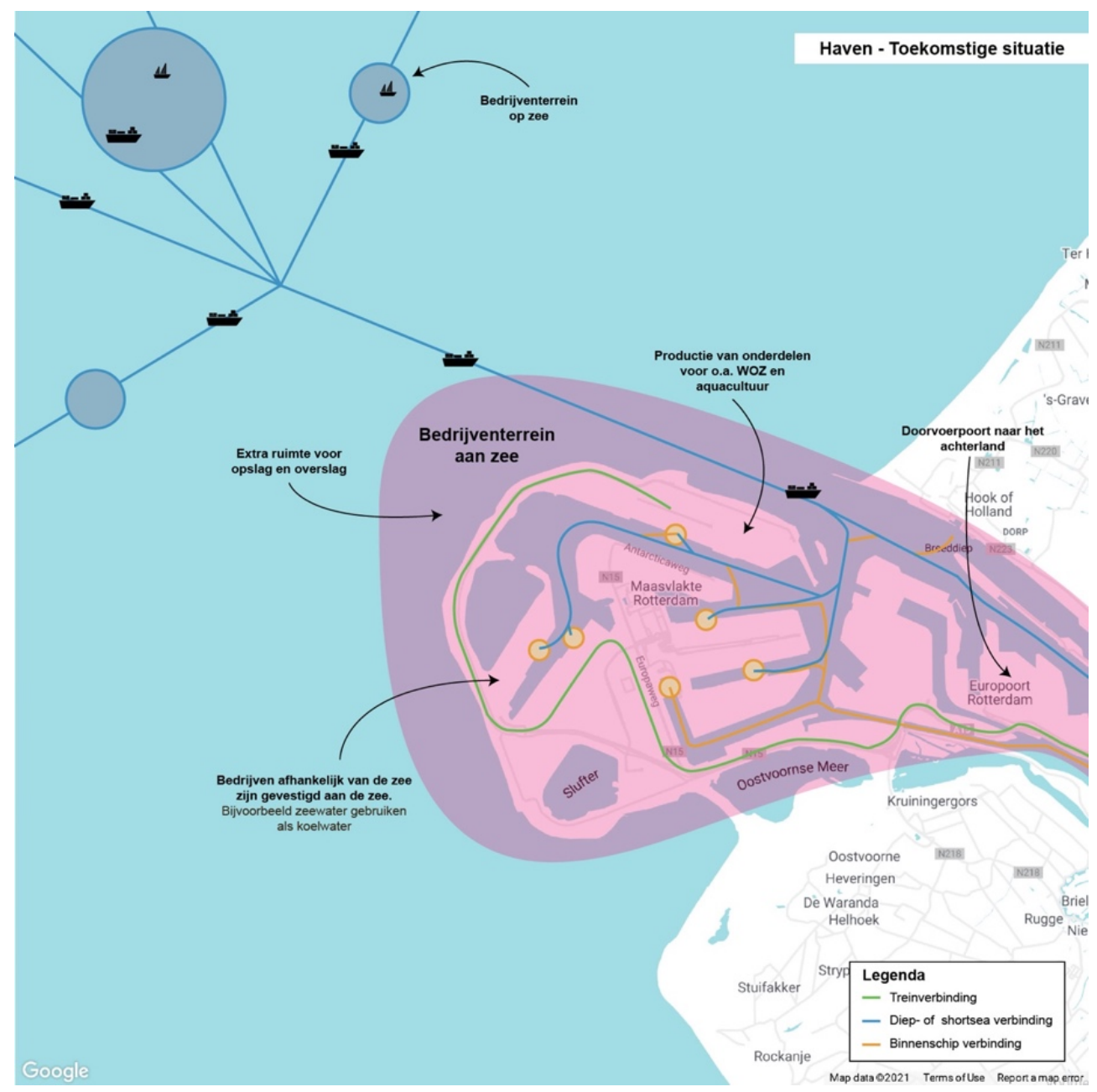

Figur 23 Toekomstige situatie bij de Haven van Rotterdam

De Scenario's I (Langzaam verder) en IV (Samen duurzaam) vormen de twee extremen, terwijl de Scenario's II (Pragmatisch duurzaam) en III (Snel vooruit) tussenliggende scenario's vormen. Omdat het graduele verschillen betreft, worden alleen beelden gepresenteerd voor de Scenario's I en IV. 


\subsubsection{Scenario I - Langzaam verder}

In Figuur 24, Figuur 25 en Tabel 6 is de ruimtelijke impact van het scenario 'Langzaam verder' schematisch weergegeven. Daarna wordt de impact toegelicht. Ten opzichte van de huidige situatie, vinden de grootste veranderingen plaats in de gebruiksfuncties scheepvaart, zandwinning en recreatie.

Tabel 6 Ruimtelijke impacts van het Noordzeescenario 'Langzaam verder' voor 2030/2050, in termen van ruimtedruk

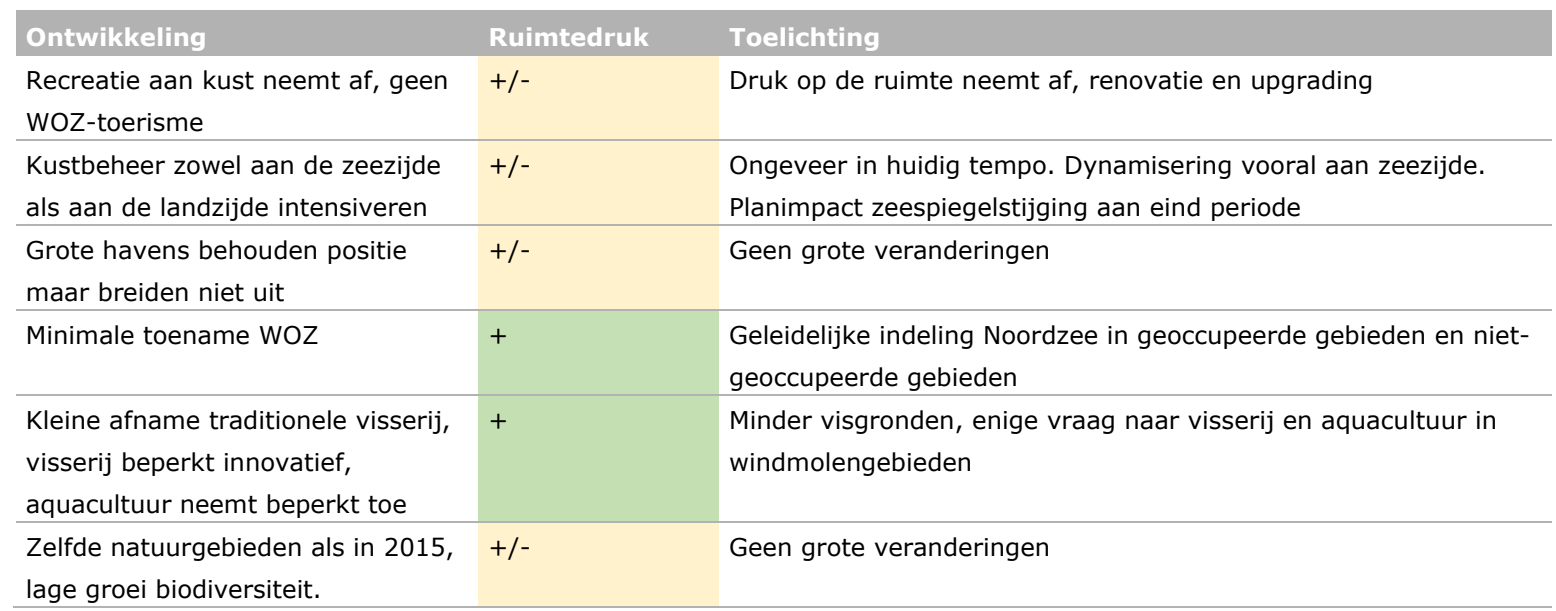

- Door de afname van toerisme aan de kust wordt de kwaliteit van het toerisme verhoogd. De ruimte voor recreatie en toerisme minder intensief wordt gebruikt en er is ruimte voor renovatie en upgraden van bestaande ruimte voor recreatie en toerisme.

- Door een langzame verduurzaming verloopt de zeespiegelstijging in een hoger tempo en liggen harde ingrepen aan de kust voor de hand.

- Door de langzame energietransitie verandert er weinig in het ruimtegebruik in de haven. Olie en gas (en dus ook bijproducten) blijven belangrijk.

- Door de langzame transitie naar duurzame energie zal er in eerste instantie weinig ruimte worden geoccupeerd door wind op zee.

- Doordat aquacultuur beperkt toeneemt en de havenactiviteiten niet uitbreiden zal de ruimte tussen de windmolenvelden zich niet snel ontwikkelen. Wel zal er enige ruimte worden ingenomen door aquacultuur.

- Er worden geen extra gebieden aangewezen met belangrijke natuurwaarden en dus blijft de druk op de ruimte op zee beperkt vanuit dit opzicht. 


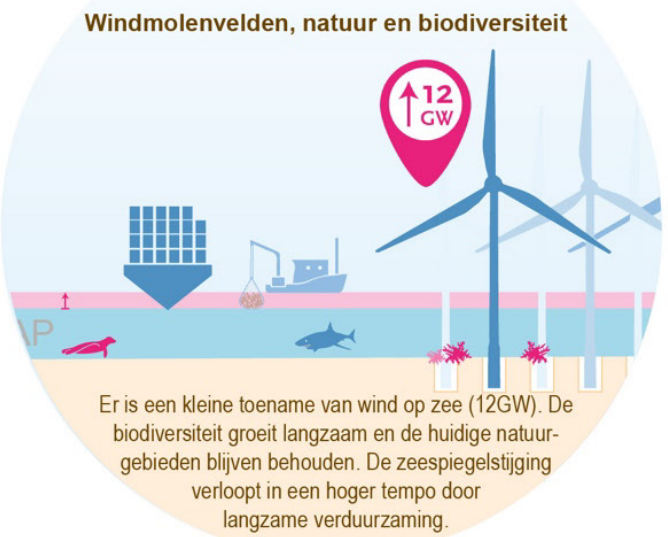

langzame verduurzaming.

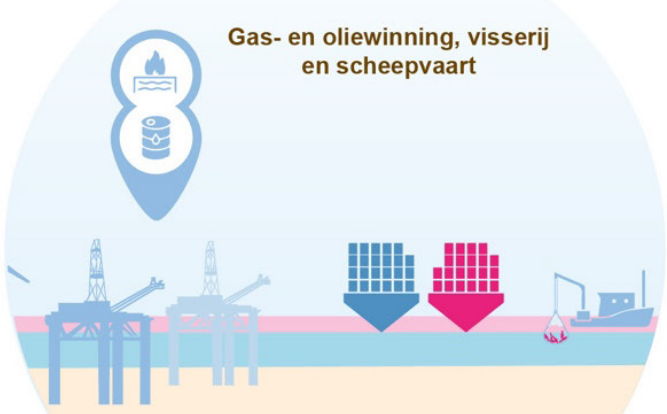

De gas- en oliewinning blijft tot na 2030. Ook is er een kleine groei van de scheepvaart terwil de traditionele visserij afneemt.

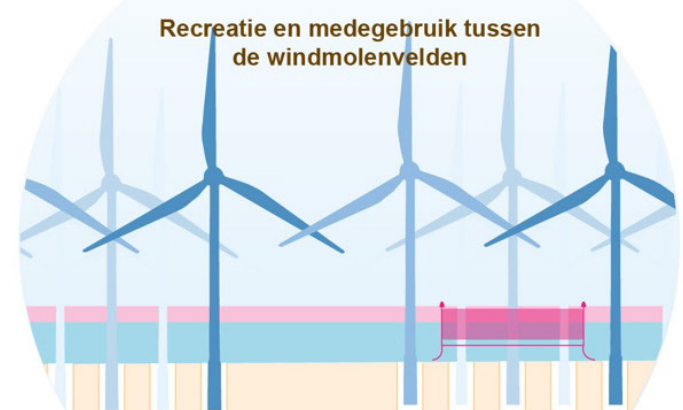

Enige ruimte tussen de windmolenvelden wordt ingenomen door aquacultuur.

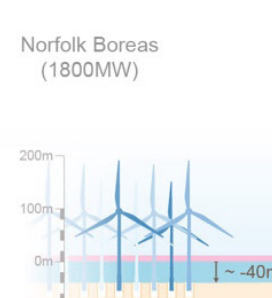

ROUTE 2030

IJmuiden Ver
(4000MW)

ROUTE 2030
Hollandse Kust West
$(1400 \mathrm{MW})$

ROUTE 2023

Hollandse Kust Zuid 1,2,3\&4

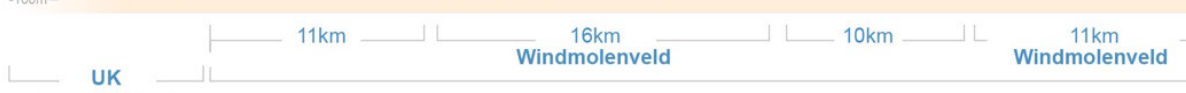
Continentaal

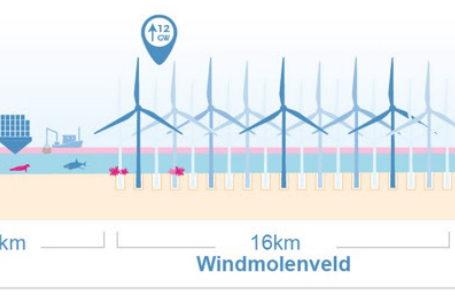

\section{Zeespiegelstijging}

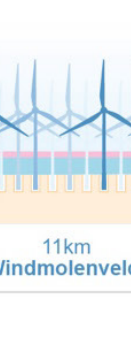

indmolenveld

\section{.}

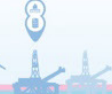

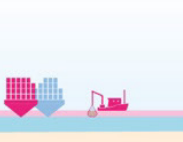
Nederlands (1520MW)

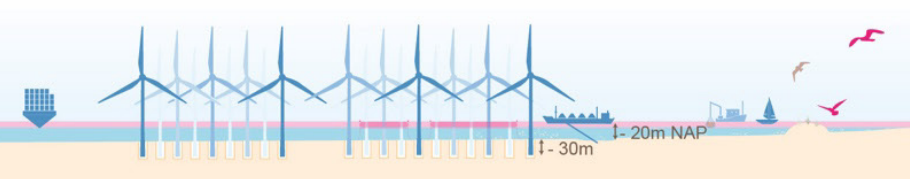

Windmolenveld ndiepe voorze

Figuur 24 Scenario I voor de zee- en windmolenvelden 


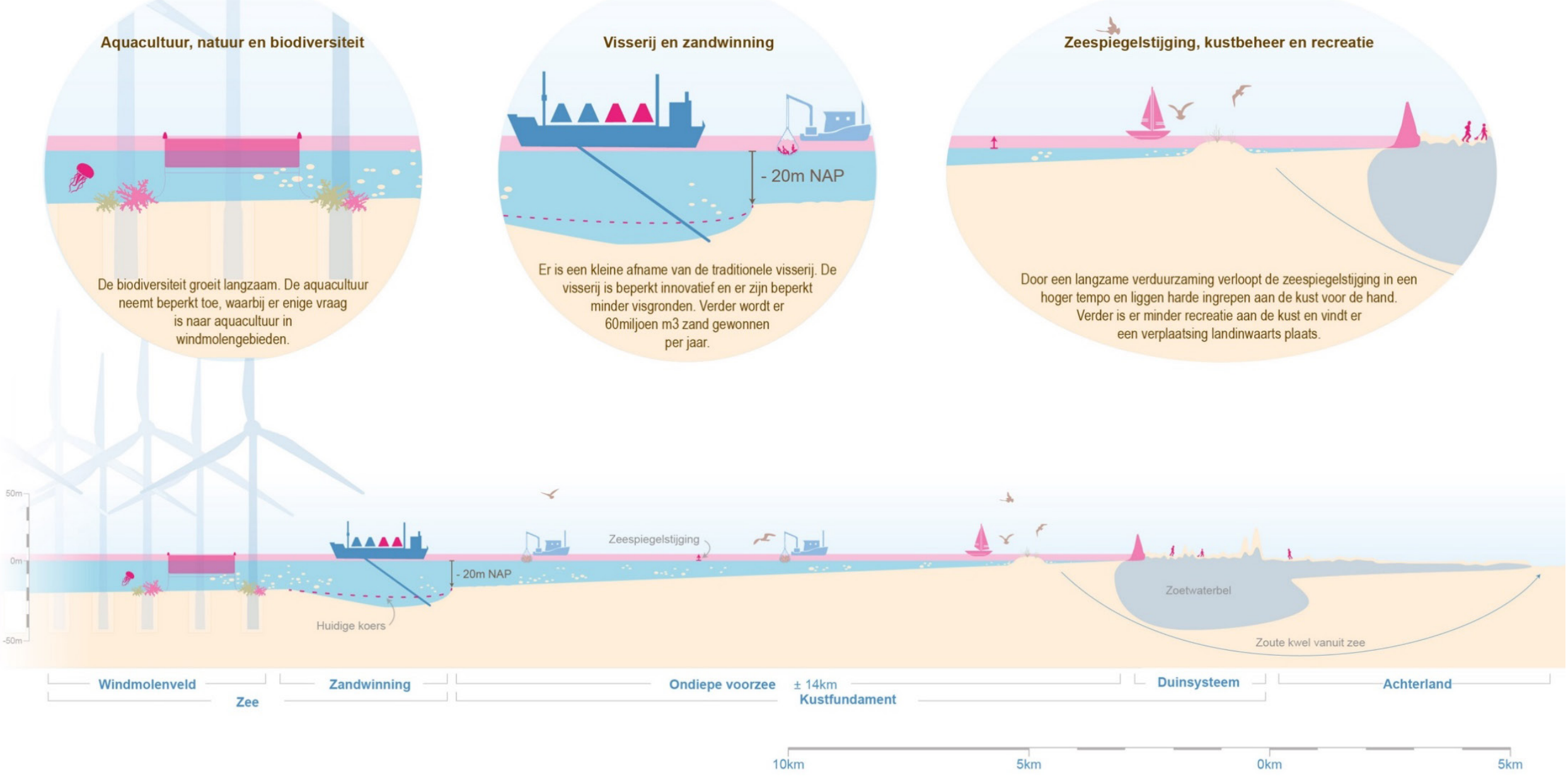

Figuur 25 Scenario I voor de dynamische kust 


\subsubsection{Scenario II - Pragmatisch duurzaam}

In Tabel 7 is de ruimtelijke impact van het scenario 'Pragmatisch duurzaam' schematisch weergegeven. Daarna wordt de impact toegelicht.

Tabel 7 Ruimtelijke impacts van het Noordzee scenario 'Pragmatisch duurzaam' voor 2030/2050, in termen van ruimtedruk

\begin{tabular}{|c|c|c|}
\hline Ontwikkeling & Ruimtedruk & Toelichting \\
\hline $\begin{array}{l}\text { Toename recreatie aan kust, WOZ- } \\
\text { toerisme en ecotoerisme }\end{array}$ & ++ & $\begin{array}{l}\text { Ruimte is beperking voor groei. Deels verplaatsing landinwaarts. } \\
\text { Deels innovatieve concepten (kuststrook) zonder grote ruimtelijke } \\
\text { ingrepen }\end{array}$ \\
\hline $\begin{array}{l}\text { Kustbeheer zowel aan de zeezijde } \\
\text { als aan de landzijde }\end{array}$ & + & $\begin{array}{l}\text { Ongeveer in huidig tempo, gericht op kennisontwikkeling } \\
\text { planimpact zeespiegelstijging aan eind periode }\end{array}$ \\
\hline $\begin{array}{l}\text { Kleine toename } \mathrm{WOZ}_{\text {, enige } \mathrm{CO}_{2-}} \\
\text { opslag }\end{array}$ & + & $\begin{array}{l}\text { Geleidelijk indeling Noordzee in geoccupeerde gebieden en niet- } \\
\text { geoccupeerde gebieden }\end{array}$ \\
\hline $\begin{array}{l}\text { Enige afname traditionele visserij, } \\
\text { beperkte innovatie, sterke groei } \\
\text { aquacultuur }\end{array}$ & + & $\begin{array}{l}\text { Minder visgronden, enige vraag naar visserij en sterke toename } \\
\text { aquacultuur in windmolengebieden }\end{array}$ \\
\hline
\end{tabular}

- Door de toename van de recreatie neemt ook de druk op de ruimte toe die voor recreatie is bestemd. Omdat er geen grote ingrepen worden gedaan in de kustlijn (lage dynamiek) zal de recreatie zich enigszins verplaatsen en ontwikkelen er innovatieve concepten die weinig beslag leggen op de ruimte.

- In dit scenario is de zeespiegelstijging kleiner doordat er wordt ingezet op verduurzaming. Het kustbeheer zal daarom gericht zijn op kennisontwikkeling. Er is ruimte en tijd om nieuwe dingen te proberen.

- Door de kleine toename van wind op zee zal er geleidelijk ruimte worden geoccupeerd door windmolenvelden, maar er blijven ook delen beschikbaar die nog niet zijn geoccupeerd.

- Doordat aquacultuur sterk toeneemt, maar de havenactiviteiten niet uitbreiden en er nog geen energiehubs zullen komen, zal de ruimte tussen de windmolenvelden vooral worden geoccupeerd door aquacultuur.

- Doordat het Nederlands Natuurnetwerk verder wordt uitgebreid, worden er gebieden aangewezen waar restricties van toepassing zijn. Hierdoor neemt de druk op de ruimte toe. Nieuw te plannen windmolengebieden zullen vaker in het noordelijke deel van de Noordzee terecht komen. 


\subsubsection{Scenario III - Snel vooruit}

In Tabel 8 is de ruimtelijke impact van het scenario 'Snel vooruit' schematisch weergegeven. Daarna wordt de impact toegelicht.

Tabel 8 Ruimtelijke impacts van het Noordzeescenario 'Snel vooruit' voor 2030/2050, in termen van ruimtedruk

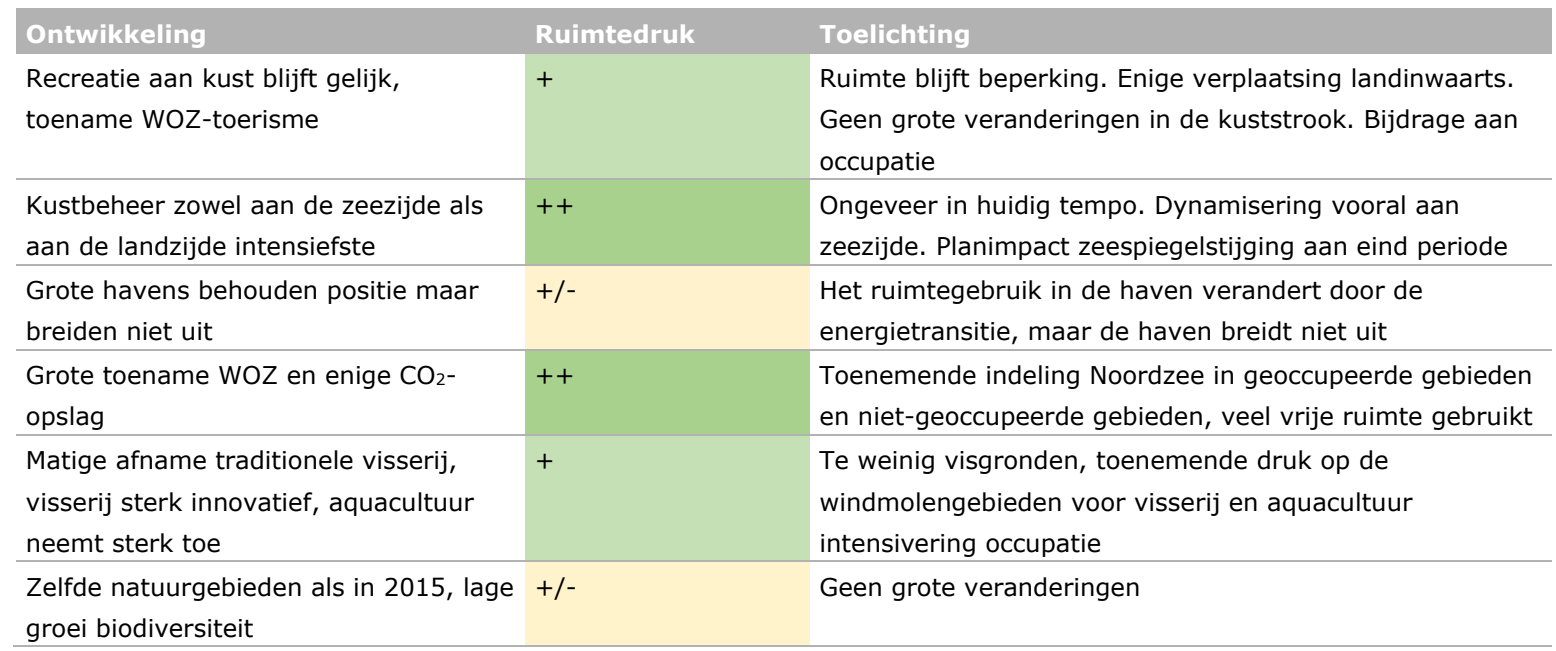

- Door de toename van recreatie gerelateerd aan wind op zee neemt het aantal vaartuigen op zee toe. Ook zijn er mogelijkheden om recreatieve functies te koppelen aan de hubs op zee. De recreatie aan de kust blijft gelijk waardoor de druk op de ruimte voor recreatie daar gelijk blijft.

- Doordat er in dit scenario niet wordt ingezet op verduurzaming maar de dynamiek wel hoog is, stijgt in dit scenario de zeespiegel het meest. Hierdoor zijn alle vormen van kustverdediging van belang, zowel harde als zachte ingrepen.

- Door de snelheid van de energietransitie verandert het ruimtegebruik in de haven. De olie- en gasindustrie en transport neemt sterk af en maakt plaats voor andere sectoren en/of functies.

- Door de hoge dynamiek zijn er veel ontwikkelingen en zal er binnen de windmolenvelden concurrentie zijn voor de beschikbare ruimte. In dit scenario is er meer WOZ gepland dan in de scenario's met een lage dynamiek dus is er ook meer ruimte voor ontwikkelingen binnen windmolenvelden.

- Objecten zoals boorplatformen worden door de snelle transitie deels overbodig. Deze objecten kunnen worden hergebruikt binnen de windmolenvelden om als basis te dienen om andere dingen aan vast te koppelen. Op deze manier kunnen hubs worden ontwikkeld voor offshore bedrijventerreinen of waterstofproductie.

- Door de sterke toename van het 'boeren op zee' heeft de aquacultuur ook een grotere weerslag op het ruimtegebruik in de havens en/of het achterland. 


\subsubsection{Scenario IV - Samen duurzaam}

In Figuur 26, Figuur 27 en Tabel 9 is de ruimtelijke impact van het scenario 'Samen duurzaam' schematisch weergegeven. Daarna wordt de impact toegelicht. Ten opzichte van de huidige situatie, vinden de grootste veranderingen plaats in de gebruiksfuncties scheepvaart, recreatieve scheepvaart, visserij, olie- en gaswinning, zandwinning, wind op zee (WOZ), recreatie en natuur.

Tabel 9 Ruimtelijke impacts van het Noordzee scenario 'Samen duurzaam' voor 2030/2050, in termen van ruimtedruk

\begin{tabular}{|c|c|c|}
\hline Ontwikkeling & Ruimtedruk & Toelichting \\
\hline $\begin{array}{l}\text { Toename recreatie aan kust en op zee, } \\
\text { WOZ- en eilanden- en ecotoerisme } \\
\text { nemen toe }\end{array}$ & ++ & $\begin{array}{l}\text { Ruimte is grote beperking. Deels verplaatsing landinwaarts. } \\
\text { Deels innovatieve concepten (kuststrook) met grote } \\
\text { ruimtelijke ingrepen. Stevige bijdrage aan occupatie }\end{array}$ \\
\hline $\begin{array}{l}\text { Kustbeheer zowel aan de zeezijde als } \\
\text { aan de landzijde }\end{array}$ & ++ & $\begin{array}{l}\text { Meer en nieuwe dynamisering aan land en zeezijde gericht } \\
\text { op kennisontwikkeling en vergroting ruimte planimpact } \\
\text { zeespiegelstijging aan eind periode }\end{array}$ \\
\hline $\begin{array}{l}\text { Grote havens versterken positie maar } \\
\text { breiden niet uit }\end{array}$ & $+/-$ & $\begin{array}{l}\text { Het ruimtegebruik in de haven verandert sterk door de } \\
\text { energietransitie }\end{array}$ \\
\hline $\begin{array}{l}\text { Maximale toename } \mathrm{WOZ}, \mathrm{CO}_{2} \text { opslag } \\
\text { en ontwikkeling energiehubs }\end{array}$ & ++ & $\begin{array}{l}\text { Vergaande indeling Noordzee in geoccupeerde gebieden en } \\
\text { niet-geoccupeerde gebieden, alle vrije ruimte gebruikt }\end{array}$ \\
\hline $\begin{array}{l}\text { Sterke afname traditionele visserij, } \\
\text { vervangen door aquacultuur }\end{array}$ & ++ & $\begin{array}{l}\text { Nauwelijks traditionele visgronden, sterk toenemende druk } \\
\text { op de windmolengebieden voor visserij en aquacultuur } \\
\text { intensivering occupatie. Sterke toename zorgt voor grotere } \\
\text { weerslag op ruimtegebruik aan de kust/achterland }\end{array}$ \\
\hline $\begin{array}{l}\text { Realisering van Natura } 2000 \text {-gebieden, } \\
\text { sterke groei biodiversiteit }\end{array}$ & ++ & $\begin{array}{l}\text { Occupatie door internationaal natuurnetwerk zorgt voor } \\
\text { extra beperkingen voor overige functies op zee }\end{array}$ \\
\hline
\end{tabular}

- Door de snelheid van innovatie en verduurzaming ontstaat er een hoge druk op de ruimte op de Noordzee.

- Door de toename van recreatie aan de kust en op zee is het denkbaar dat in de kustlijn ingrepen worden gedaan om meer ruimte te creëren voor recreatie. Denk bijvoorbeeld aan het creëren van nieuwe, naar buiten gerichte, kustbogen bij de drukke punten aan het strand die zich aan harde objecten 'vastzetten' (bijvoorbeeld, artificiële riffen). Dit is nu geen beleid, en dergelijke ingrepen gaan met veel onzekerheden gepaard. Maar het is belangrijk om hier ervaring mee op te doen omdat bij zeespiegelstijging dit soort ingrepen tot het repertoire van kustmaatregelen zou kunnen behoren. In dit specifieke scenario is er meer tijd dan in de andere scenario's om kennis en ervaring te ontwikkelen, mede in combinatie met zachte ingrepen (zie ook het volgende punt).

- Door de snelheid van de verduurzaming verloopt de zeespiegelstijging geleidelijk en kan de kustverdediging voornamelijk worden versterkt door zachte ingrepen zoals zandmotoren. Deze vorm van kustbeheer neemt meer ruimte in dan harde ingrepen.

- Door de snelheid van de energietransitie verandert het ruimtegebruik in de haven. De olie- en gasindustrie en transport neemt sterk af en maakt plaats voor andere sectoren en/of functies.

- Door de maximale transitie naar duurzame energie wordt het nog belangrijker om de ruimte tussen de windturbines beter te gebruiken en is er ruimte voor diverse functies tussen de windturbines. Door de hoge dynamiek zijn er veel ontwikkelingen en zal er ook binnen de windmolenvelden concurrentie zijn voor de beschikbare ruimte.

- Objecten zoals boorplatformen worden door de snelle energietransitie overbodig. Deze objecten kunnen worden hergebruikt binnen de windmolenvelden. Ze kunnen als basis te dienen om andere dingen aan vast te koppelen. Op deze manier kunnen hubs worden ontwikkeld voor offshore bedrijventerreinen of waterstofproductie.

- Door de sterke toename van het 'boeren op zee' en de concurrentie om ruimte met andere functies zal er een verkaveling ontstaan binnen de windmolenvelden. Ook heeft de aquacultuur een grotere weerslag op het ruimtegebruik in de havens en/of het achterland vergeleken met andere scenario's. 

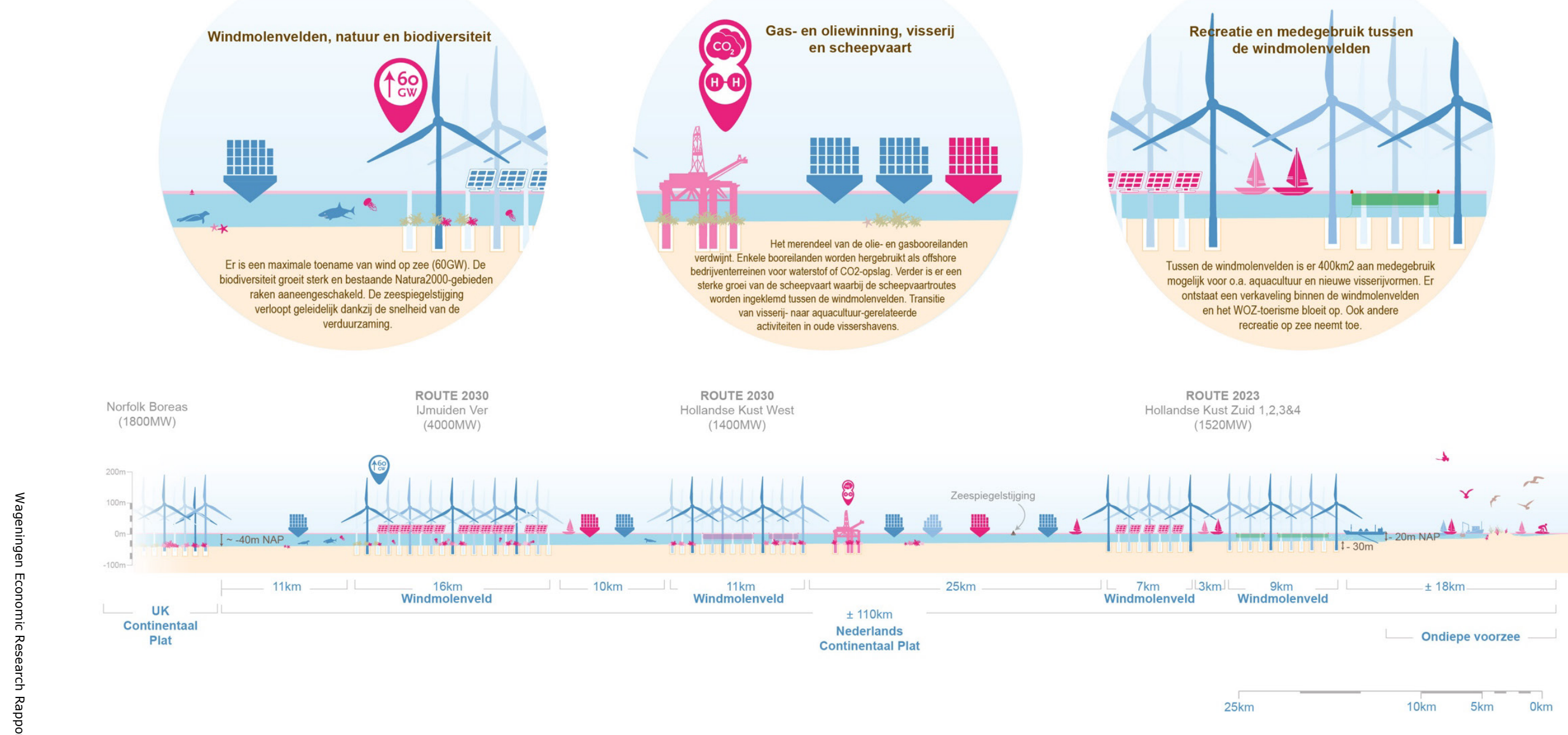

Figuur 26 Scenario IV voor de zee- en windmolenvelden 


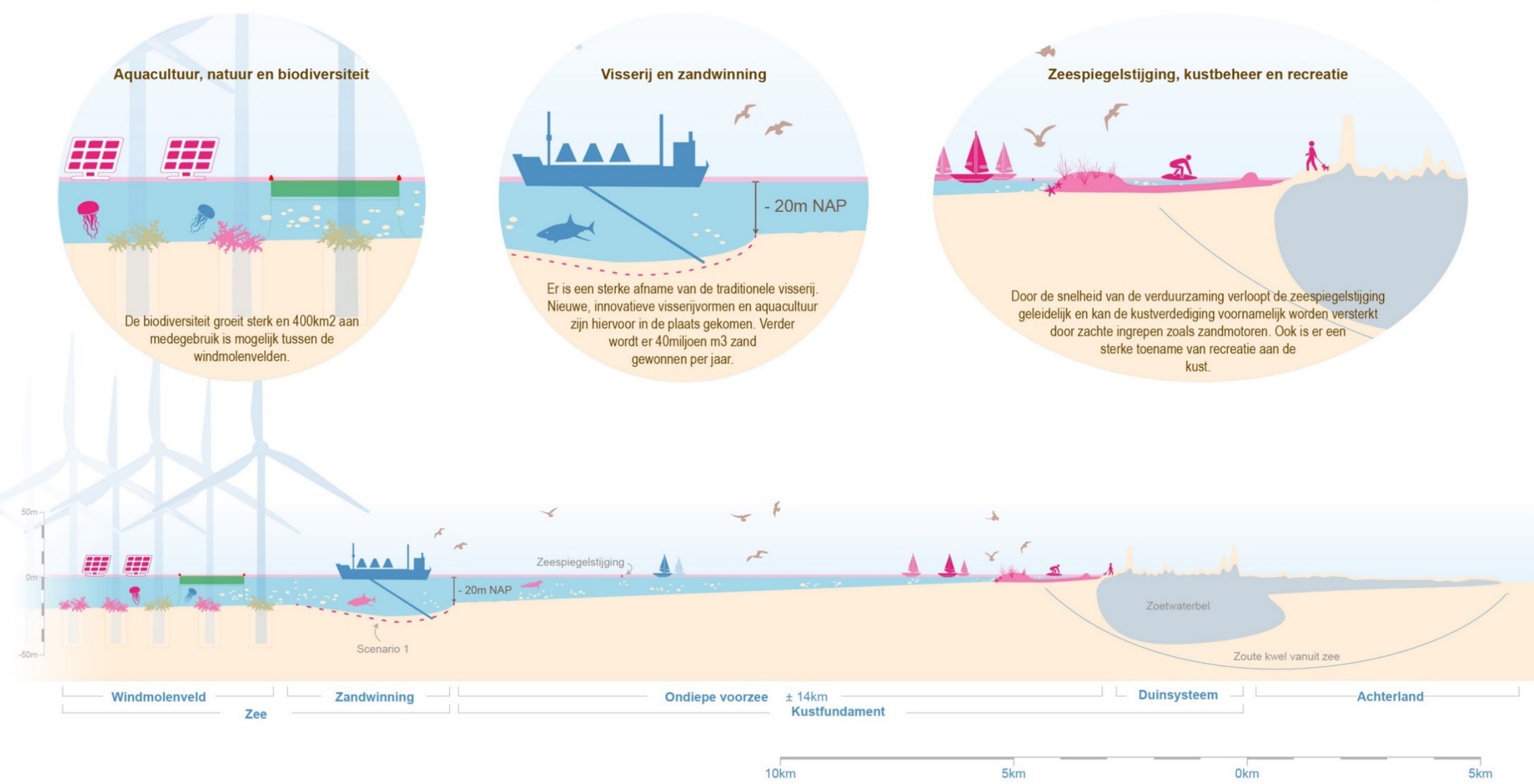

Figuur 27 Scenario IV voor de dynamische kust 


\section{$5 \quad$ Beleid en bestuur}

Dit hoofdstuk geeft een overzicht van de maatschappelijke opgaven, de gerelateerde rollen en verantwoordelijkheden, en beleidsinstrumenten van de provincie en relevante actoren die deze opgaven met zich meebrengen (Sectie 5.2). We kijken daarbij naar het lerend vermogen van het provincie netwerk (Sectie 5.3) en de verschillen en overeenkomsten tussen de vier toekomstscenario's (Sectie 5.4). We vertrekken echter vanuit een schets van de huidige bestuurlijke situatie (Sectie 5.1).

\subsection{Grote bestuurlijke drukte maar ook ruimte voor regie}

De Noordzee raakt steeds voller, met meer windparken die indirect ook ruimte op zee en kust vereisen, met natuur, recreatie, visserij en vaarroutes die in het gedrang komen te staan. Ook in termen van beleid en bestuur is het druk. Voor de vele uitdagingen rond veiligheid tegen overstromingen, de omgang met onzekerheden en de veelvuldige benutting van de kust, hebben de gezamenlijke overheden van de stuurgroep Deltaprogramma Kust een kompas voor de kust gemaakt met een gezamenlijke koers: de Nationale Visie Kust (I\&M, 2013). In de visie leggen de partijen de veiligheidsopgaven en de ruimtelijke ambities uit, en de koers is gericht op het verbinden van opgaven, met maatwerk per locatie. Samenwerking gebeurt onder meer via het Kustpact (I\&W, 2017), waar de overheden, natuurorganisaties, de recreatiesector en drinkwaterbedrijven de verschillende waarden van de kust uitleggen en aangeven hoe ze samen de toekomst van de kust vormgeven. De kustprovincies hebben deze afspraken vastgelegd in de provinciale verordening ${ }^{8}$.

Als gevolg hiervan zijn er een groot aantal Rijkspartijen die zijn betrokken bij de Noordzee. Het Ministerie van Binnenlandse Zaken voert de regie over het Kustpact; het Ministerie van Economische Zaken over wind op zee (WOZ); het Ministerie van Infrastructuur en Waterstaat over het Programma Noordzee; en het Ministerie van Landbouw, Natuur en Voedselkwaliteit voert de regie over de Natuurvisie Grote Wateren en Natura 2000. Maar ook tal van anderen zijn hierbij betrokken.

De brede betrokkenheid komt in essentie omdat vele vraagstukken en sectoren geraakt worden door het beleid. Veel van het beleid is gericht op een balans te vinden tussen de ruimtelijke en economische contrasten tussen i) de kust als vrij toegankelijke ruimte, vaak open en onbebouwd met een grote natuur- en belevingswaarde en aantrekkelijk voor toerisme en recreatie; en ii) het faciliteren van de economie aan en veiligheid van de kust. Hier lag de aanleiding voor de Kustpact uit 2017 doordat Natuurmonumenten, Natuur en Milieufederatie Zuid-Holland, Zeeuwse Milieufederatie, Het Zeeuws Landschap, Zuid-Hollands Landschap en Stichting Duinbehoud, als initiatiefnemers van de Coalitie Bescherm de Kust, zich zorgen maakten over de ontwikkelingen van de kustbebouwing en de waarden van het kustgebied in de Zuidwestelijke Delta. Vervolgens ontstond er veel commotie toen het Rijk kenbaar maakte om, waar mogelijk en vanuit het belang van waterveiligheid, meer ruimte te bieden voor ruimtelijke ontwikkelingen aan de kust (Kustpact; I\&W, 2017).

De Nationale Visie Kust (I\&M, 2013) en het Kustpact (I\&W, 2017) werd een vertrekpunt om te komen tot een gezamenlijk visie en de basis voor de verdere planvorming in structuurvisies, verordeningen en bestemmingsplannen. De bestuurlijke drukte is te begrijpen door een opsomming van waarden die beschermd moeten worden in het beleid: veiligheid tegen overstromingen; de aantrekkelijkheid en economische kracht van de kustzone behouden en te versterken; de drinkwatervoorziening; unieke natuurwaarden; en wonen, werken, landschap, visserij, scheepvaart, recreatie, religie, waterbouw en militaire verdedigingswerken.

\footnotetext{
${ }^{88}$ Zie https://www.deltaprogramma.nl/gebieden/kust/voorkeursstrategie.
} 
In het Kustpact (I\&W, 2017) onderschrijven de partijen de bestuurlijke verantwoordelijkheden, die sinds de Structuurvisie Infrastructuur en Ruimte (I\&M. 2012) gericht is op een ruimtelijk beleid gebaseerd op regionaal maatwerk, met de volgende kernpunten.

- De verantwoordelijkheid voor het landschapsbeleid en verstedelijking ligt bij provincies en gemeenten.

- Het Rijk is, samen met de waterschappen, verantwoordelijk voor de waterveiligheid als nationaal belang, inclusief de drinkwatervoorziening (zie I\&W, 2014).

- Provincies zijn regisseurs van het regionale en interregionale kustbeleid en verantwoordelijk voor het natuur- en landschapsbeleid, op basis van onder andere de Wet ruimtelijke ordening en de Wet natuurbescherming (in werking vanaf 2017).

- Gemeenten zijn verantwoordelijk voor de inrichting en het gebruik van de ruimte op lokaal niveau, via bestemmingsplannen.

- Waterschappen en Rijkswaterstaat zijn verantwoordelijk voor de zorg voor het watersysteem, met de primaire waterkeringen in de kustzone (waterveiligheid).

- De provincies (Zuid-Holland, Noord-Holland, Zeeland) actualiseren hun beleid voor de kustzone, met zonering, in overleg met betrokken gemeenten, naastgelegen provincies, betrokken waterschappen, Rijkswaterstaat, natuur- en milieuorganisaties, drinkwaterbedrijven, StrandNederland, RECRON, KHN, HISWA, NBTC, ANWB, Staatsbosbeheer en het Rijk.

We noemen ook het voornemen uit de Nationale Visie Kust (I\&M, 2013) om te werken vanuit het idee van een 'kustcommunity', gebaseerd op de principes van lerend werken, het verbinden van publieke en private partijen en het uitwisselen van ervaringen over oplossingen voor kustveiligheid en kustontwikkeling.

Uit bovenstaande zien we de contouren van de bestuurlijke drukte voor de Provincie Zuid-Holland maar we zien ook de ruimte voor de provincie onder meer als uitvoerende instantie. De provincie is een overheid die behoefte voelt om integraal en samenhangend te werken. Zo'n verhaal is ook te lezen in de Toekomstdialoog over de Nexus die een jaar geleden werd gehouden. Maar ook de brede groep stakeholders actief in dit project voelen deze behoefte aan samenhang en richting. En, ondanks ontmoetingsplekken in de diverse beleidstrajecten, is er ook behoefte aan meer ontmoetingen met goede discussies over het beleid voor de toekomst. Want niet alleen is er behoefte aan een integraal beleid maar ook een integrerend beleid. De boodschap van de stakeholders is dan ook dat het beleid niet mensen buiten de boot moet laten vallen. En hiermee komen we tot ons eerste en algemene observatie, zoals ook werd aangegeven door stakeholders tijdens de tweede ronde van workshops (WS-Fase2), een nieuw, integrerend en includerend beleid. Zo sprak men bijvoorbeeld ook over een toekomst met een Provincie Noordzee. Of dat wenselijk of haalbaar is laten we in het midden, maar het wijst wel op de behoefte aan een meer integrerende en includerende aanpak vanuit beleid.

\subsection{Overkoepelende beleids- en bestuur aanbevelingen}

Een van de krachtigste signalen uit de tweede ronde van workshops (WS-Fase2) is de wens om een toekomst met een meer integrerend en includerend beleid voor de kust en zee. In 2020 is dit echter een onwaarschijnlijk toekomst. Uit dit project komt een beeld van de Provincie Zuid-Holland naar voren waar over de Noordzee weliswaar beleidsstukken geschreven zijn maar die echter weinig zichtbaar en geoperationaliseerd zijn, hetgeen leidt tot weinig profilering naar buiten toe. Er is sprake van een brei van beleid en een kluwen van belangen van de EU en het Rijk, tot de provincie en de gemeenten toe. Toch is er ook een onderstroom van mensen binnen en buiten de provincie die wel de grotere lijnen zien en verder willen ontdekken. Deze mensen zouden nu kunnen mobiliseren voor een grote stap naar meer focus op de veelzijdige zee en de relatie zee en land.

\subsubsection{Opgaven}

Voor het mobiliseren van de krachten tonen we hier een beeld van de talrijke en veeleisende maatschappelijke opgaven voor de provincie:

- Het faciliteren van een dynamisch kustbeheer, daarbij werkend aan een dynamisch, samenhangend en integraal kustbeheer met prioritaire thema als veiligheid, duurzaamheid, klimaat, bouwen met 
natuur, verbreding kust/duinen voor een groter zoetwaterbel, verzilting en voedselzekerheid. Een bovenregionale strategie voor de Zuidwestelijke Delta is genoemd als optie.

- Het werken aan duurzame energie, met de ruimtelijke inpassing van de aanlanding, transformatie, opslag en infrastructuur voor de energie.

- Het haven-industriële complex, waar de provincie veel baat bij heeft want er zijn provinciale belangen. Elektrificatie van de industrie hoort hierbij, als het belang van de elektrificatie niet wordt gewaarborgd dan heeft dat impact op de businesscase van windenergie op zee en de prijs van elektriciteit. Aldus de opgave voor de provincie de elektrificatie economisch in te kaderen.

- Natuur dynamiseren en integreren, zowel aan de binnenkant (land) als de buitenkant (zee) evenals tussen Noordzee kustprovincies, is van belang voor het behalen van natuurdoelen. Dit vereist inzet op integrale oplossingen en het leggen van verbanden tussen beleidsagenda's, zoals kustbeheer, energietransitie en natuurbeleid).

- Duurzaam stimuleren en faciliteren van toerisme en recreatie, voorwaardenscheppend voor een economie de sectoren te helpen organiseren en ontwikkelen.

- Het ontwikkelen van een visie op voedsel, welke momenteel ontbreekt terwijl de belangenstrijd al op visieniveau begint. Voedsel is nu teruggedrongen tot vergunningen terwijl er behoefte is aan een stip aan de horizon voor voedsel.

- Het werken aan de transitie van de visserij, en dat gaat over zowel de kaders voor visserij als het helpen en stimuleren van vissers.

De essentie voor al deze opgaven is het omgaan met en het faciliteren van de concurrentie om ruimte. Deze opgaven vragen echter ook om in verband te worden gezien, met een meer integrale aanpak waar meer zeewaarts gedacht moet worden. In termen van beleid en bestuur is de Noordzee behoorlijk druk. Stakeholders stellen dat een dialoog zowel binnen als buiten de overheden nodig is over de links en de maatschappelijke kosten-baten, met overtuigende links tussen de onderwerpen en de hele kustverdedigingsstructuur. Zo komt bouwen met natuur naar boven als onderdeel van een verbrede kustlijn maar niet iedereen is ervan overtuigd dat bouwen met natuur de juiste weg is. Voor een meer gezamenlijk aanpak zou een gemeenschappelijk visie hierop nuttig zijn. Dit vereist evaluatie, discussie, ontwerpen en weer evaluatie, discussie en meer ontwerp. Uiteindelijk moet dan meer zicht op de rollen en verantwoordelijkheden voor de opgaven worden verkregen.

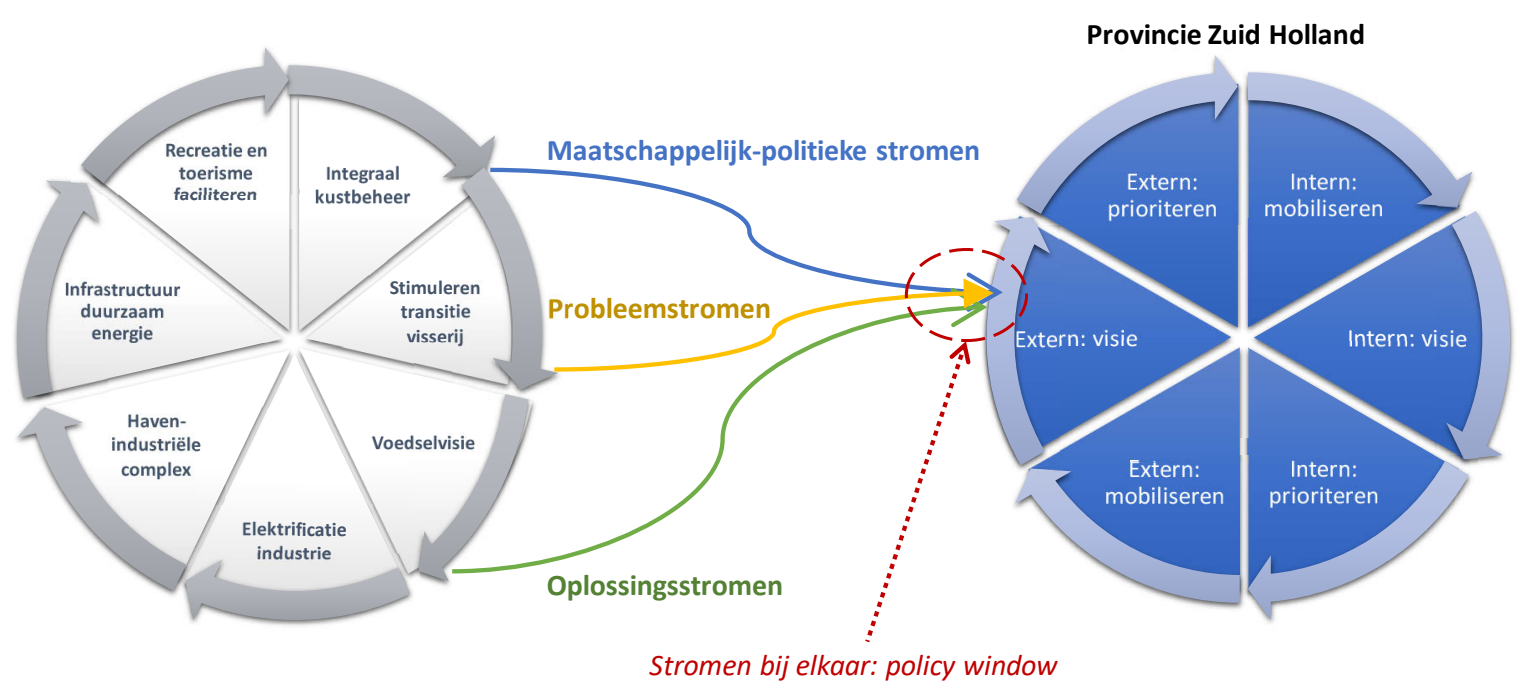

Figuur 28 Stromenmodel met opgaven (linker wiel) en planning (rechter wiel) voor de Provincie Zuid-Holland

Het stromenmodel biedt een weergave van hoe de opgaven (linker wiel) tot een visie met aanpak (rechter wiel) kan komen (Figuur 28). De figuur illustreert dat er momentum moet zijn, een policy window die ontstaat als maatschappelijk-politieke 'stromen' (zoals een politiek besluit om tot meer windenergie te komen) samen komen met probleemstromen (zoals niet in staat zijn om te voldoen aan de Parijs-afspraken over duurzaam energie) en oplossingsstromen (zoals publieke en private bereidheid om te investeren in windparken op de Noordzee). 


\subsubsection{Rollen en verantwoordelijkheden}

Met zoveel opgaven en betrokkenen zien we hier ruimte voor een provincie die het voortouw neemt met betrekking tot een gezamenlijk en gecoördineerd kustbeheer en -beleid over de gehele Noordzeekust door Rijk, Noordzeeprovincies en -gemeenten, met een taakgerichte aanpak voor de korte en lange termijn. Centraal staat welke maatschappelijke opgaven de provincie dient op te pakken en met welke rollen en verantwoordelijkheden. Voor deze vraag beginnen we met een overzicht van rollen (zie Figuur 29).

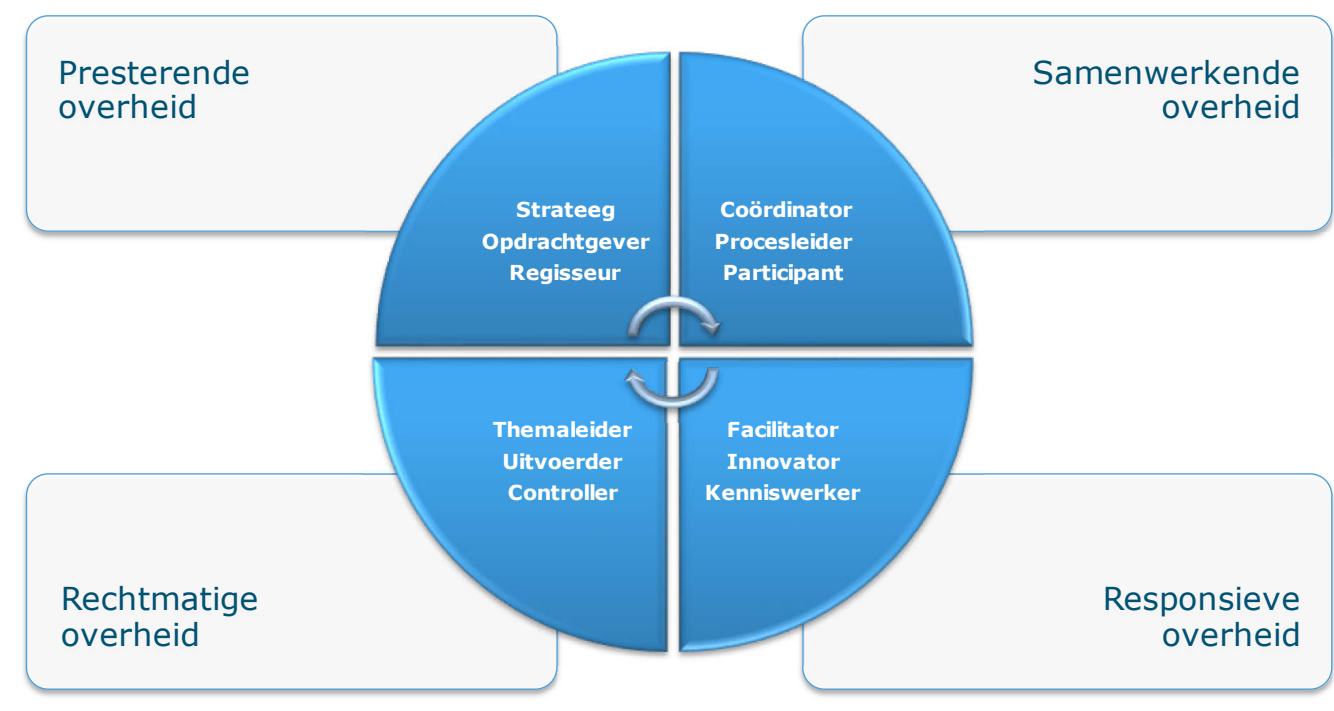

Figuur 29 Rollen van de Provincie Zuid-Holland (gebaseerd op Van der Steen et al., 2015)

De twee assen hier zijn de volgende (Van der Steen et al., 2015):

i) Links 'vanuit de overheid naar de samenleving' en rechts 'vanuit de samenleving naar de overheid'. Links neemt de overheid grotendeels zelf de beslissing en is dominant, en aan de rechter kant is er veel meer samenwerking en minder de dominante overheid.

ii) Boven 'vanuit randvoorwaarden naar resultaten' (het realiseren van beleid) en beneden 'vanuit resultaten naar randvoorwaarden' (politiek/besluitvorming).

In de praktijk vervult elke organisatie en medewerker zijn taken met aspecten van meerdere rollen. Er zitten wel vaak spanningen tussen de linker kant met de presterende en de rechtmatige overheid, die dan vaak stevig moet optreden; en de rechter kant van de samenwerkende en responsieve overheid die meer als partner naar voren komt. Het gaat ook om het willen, mogen en kunnen. En dat is weer gelinkt aan het gevoel voor urgentie, verwachtingen, sterke en zwakke punten, en vertrouwen. Voor de provincie gaat het vaak om het maneuvreren in een complexe en dynamische netwerkmaatschappij. Hier speelt dat de echte bewegingsvrijheid niet vast te leggen is, die is sterk gekoppeld aan zowel eigen ambitie als de ambitie van anderen. Kansen ontstaan ook doordat anderen kansen - regie - laten liggen. Maar wat je kan hangt sterk af van wat je wil en hoe graag je het wil; en zoals Ralph Waldo Emerson zei: 'Nothing great was ever achieved without enthusiasm.' Dit vergt wel meer werk aan de koers die de provincie wil varen en die dient weer sterker gekoppeld te worden aan (het werken aan) de slagvaardigheid van de provincie. We zien in dit onderzoek genuin enthousiasme bij de provinciemedewerkers maar ook kansen die er zijn om deze meer richting en vaart te geven.

Voor de provincie is het de vraag waar het wil zijn over 20 jaar. Welke vergezichten of stipjes op de horizon zijn belangrijk en hoe komt de provincie daarnaartoe. Uit de workshops hebben we vier onderwerpen gehaald waarop ingezet dient te worden (Figuur 30):

- De coördinatie tussen de vele belangen en lagen overheden is stroef. Er is verkokering en dat vraagt ontschotting en misschien vooral een andere communicatie. Vaak is onduidelijk wat er nu al kan en wat er nodig is van institutioneel verandering. Ondernemers bijvoorbeeld voelen dat ze van het kastje naar de muur worden gestuurd. Er zijn zo veel schuivende panelen, met diverse belangen, 
dat het geheel te ingewikkeld is en dat de aandacht niet op kansen komt te liggen. Coördinatie kan ook door een overtuigende verhaallijn over de toekomst neer te zetten. Dat kan op inspirerende wijze de verkokering tegengaan door meer integrerende oplossingen te bieden.

- Er is ook behoefte aan een overheid die ontzorging biedt voor allen die buiten de prioritaire overheidsschema's vallen.

- Voor een samenhangend beleid vragen stakeholders ook meer co-creatie van beleid met een breed deelname van de maatschappij, als een soort doorlopende workshop.

- De provincie dient dit te koppelen aan vernieuwing via co-innovaties, als een snelweg voor het faciliteren van goede plannen. Campus@Sea is een voorbeeld van een ontmoetingsplaats voor dit soort vernieuwingen. Co-innovatie kan echter leiden tot een behoefte aan nieuwe verhoudingen en bevoegdheden van de betrokkenen. Het is in wezen niet een apolitiek technisch oefening maar een oefening die tot nieuwe beleidskeuzes en randvoorwaarden voor de praktijk kan leiden.

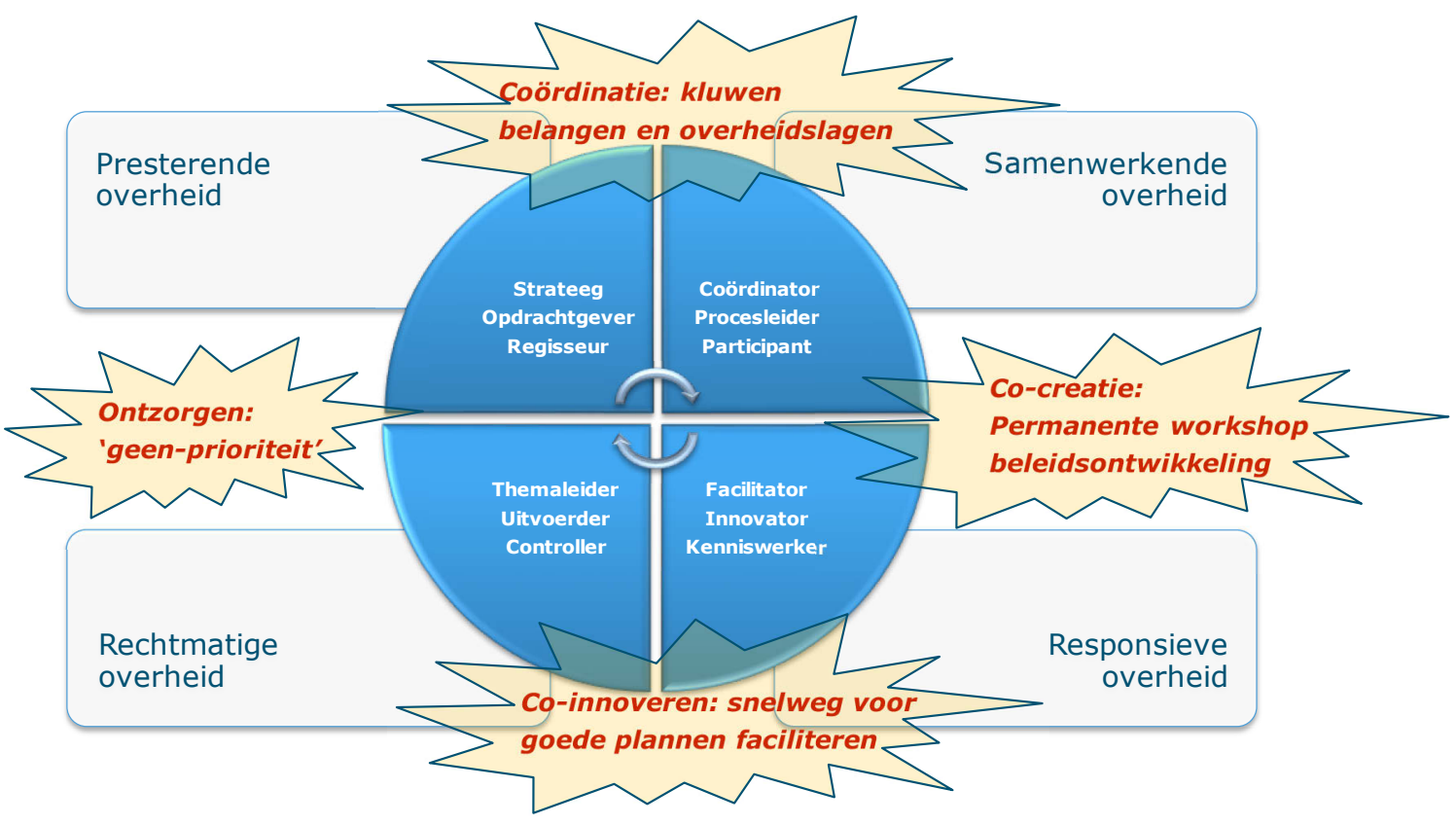

Figuur 30 Rollen van de Provincie Zuid-Holland en de aanpak op hoofdlijn uit de workshops

Uit de workshops kwamen actiepunten naar voren die een relatie leggen met Figuur 30:

1. $\mathrm{PZH}$ als coördinerend verbinder werkt aan een integraal en samenhangend visie voor de activiteiten op zowel zee als op land/kust;

2. $\mathrm{PZH}$ organiseert co-creatie door structureel overleg te voeren met alle relevante betrokkenen. In het bijzonder organiseert zij het overleg met de verschillende kustprovincies;

3. $\mathrm{PZH}$ faciliteert co-innovatie voor een shift van de huidige naar toekomstige rollen en verantwoordelijkheden, op een ambitieuzer en helderder manier dan nu; en

4. $\mathrm{PZH}$ zit als ontzorger steviger aan tafel waar de zaken nadrukkelijk haar taken en verantwoordelijkheden raken.

PZH ontwikkelt meer samenwerking met andere betrokkenen voor de visie, prioriteiten en de inhoudelijke activiteiten en hoe zij hier een rol in kan spelen. Veel partijen spreken de behoefte uit naar een sterker invulling van de rol als verbinder, tussen de rollen. Er liggen kansen doordat er vele overheidsinstanties zijn met een eigen aanpak en agenda maar dat er ook taken zijn rond de regie van samenhang die blijven liggen. Bovendien lijken er nu twee werelden te zijn die elkaar niet kennen: die van de zee en die van het land. Ook in termen van governance zijn dit vaak twee werelden. De Provincie kan daar wat aan doen:

- Door de ogen en oren van alle stakeholders te zijn: een planmatig en structureel matschappelijk overleg met relevante stakeholders opzetten om de benutting van de Noordzee systematisch en met overweging van alle belangen vorm te geven; 
- Investeren in bestuurlijke consistentie voor de hele waardeketen, op zee en op land, voor de hele overheid en de maatschappij: de provincie kan in eerste instantie bouwen aan relaties die al goed zijn, zoals de samenwerking met RWS; en

- Intern mobiliseren en integreren: de provincie dient dan ook intern meer gevoel van urgentie, nut en noodzaak op te bouwen evenals interne versnippering tegengaan die ten koste gaat van slagvaardigheid naar buiten.

Concreet dient de provincie in te zetten op:

- Het lanceren van een doorlopende workshop voor beleidsontwikkeling rond integraal kustbeheer door middel van dialoog tussen burgers, bedrijven en beleidsmakers, waar ook kenniswerkers en ontwerpers ingezet worden.

- Opzetten van een beleidsagenda (visie met prioriteiten) voor meer samenhang in de ruimtelijke dynamiek voor de kust en op de Noordzee. Een intensievere verbinding van de ruimtelijke ordening op zee en op land kan ertoe bijdragen dat initiateven, zoals Nationaal Park Hollandse Duinen, NL Delta en Zandmotoren, onderdeel worden van een integrale afweging en daarmee wellicht ook, in aangepaste vorm, kansrijker.

- Integratie met samenhang tussen natuur, voedsel, infrastructuur, recreatie, wonen, water, scheepvaart en energie, welke allemaal bij elkaar komen aan de kust en op de Noordzee. Dit vraagt het faciliteren van waardeconflicten en strijd om doelen en middelen, evenals samenhang en integrale beleidsuitvoering rond kustbeheer, kustzonering, aanlanding energie, visserij, (eco)toerisme/recreatie, natuur, zandsuppletie en duinen.

- Samenwerking met gevestigde belangen maar ook nadrukkelijk daarbuiten, zoals met het Internationale Architectuur Biennale Rotterdam (www.iabr.nl), waar men sinds 2001 architectuur en stedenbouw werkt aan een langlopend ontwerpend onderzoekstraject samen met overheden en andere stakeholders.

- Programma Stimulerende Noordzee. Een handelingsperspectief tot 2040 als stimulans voor investeringen met nieuwe business cases, onshore \& offshore services voor ondernemen en ondernemers op en bij de Noordzee.

- Ambitieus kenniscentrum, aangevuld met een versterking van beleidsinstrumenten, kan wind op zee opstuwen tot een omvangrijke nieuwe economie, ook via medegebruik van windmolenvelden voor, bijvoorbeeld, zeewierteelt, visserij en natuur. De Provincie heeft misschien niet veel directe zeggenschap over de windmolenvelden op zee, maar er zijn volop kansen voor meer inzet op hoe medegebruik van de windmolenvelden uitgevoerd wordt.

- De stroom materialen en nutriënten van de Noordzee, zoals offshore teelt en vangst van en een nearshore blueport voor zeewier en vis. Verbinding tussen voedsel/visserij, energie (medegebruik windparken), ecologie (habitat) en recreatie (bijvoorbeeld sportvisserij) evenals het realiseren van voorzieningen en infrastructuur er omheen zijn hierbij van belang.

- Voedsel uit de Noordzee. Er zijn vele belangen in het geding op de Noordzee. Voedsel terugdringen tot vergunningen zonder visie heeft geen toekomst en hier liggen kansen. Meer provinciale regie op de visserij bijvoorbeeld kan sterk ondersteunend werken voor de hoe de ambitie van de Provincie omgezet kan worden in een meer actieve rol.

- Internationaal Natuurnetwerk Kust zorgt voor biodiversiteit. Een samenhangend beheersplan voor de kust in een platform voor samenwerking met nationale en internationale partners. Betrek hier het Nationaal Park Hollandse Duinen.

- Werken aan een integrerende en includerende Noordzee. De kustprovincies kunnen in de toekomst meer zorgdragen voor de Noordzee en de mensen langs de kust.

Momenteel is de Omgevingswet de volgende stap in de beleidsontwikkeling en deze is bedoeld als een omvattend kader voor het omgevingsrecht en ook voor een vereenvoudiging in wetgeving en decentralisatie van verantwoordelijkheden naar lagere overheden te bewerkstellingen. Nu zijn er aparte wetten voor bodem, bouwen, geluid, infrastructuur, mijnbouw, milieu, monumentenzorg, natuur, ruimtelijke ordening en waterbeheer (Oude Elferink, 2020). Oude Elferink (2020) stelt vast dat deze verbrokkeling tot afstemmings- en coördinatieproblemen leidt en verminderde kenbaarheid en bruikbaarheid voor alle gebruikers. De Omgevingswet heeft ook als doel om duurzame ontwikkeling beter te integreren in het omgevingsrecht. De Omgevingswet is bedoeld om een groot aantal wetten te vervangen, zoals de Waterwet, de Ontgrondingenwet, de Wet natuurbescherming, de Wet algemene bepalingen omgevingsrecht, de Wet beheer rijkswaterstaatswerken, de Wet 
bodembescherming, de Wet milieubeheer, de Wet ruimtelijke ordening en de Wrakkenwet. Ook zal de Omgevingswet delen van andere wetten vervangen, waaronder de Wet milieubeheer en de Mijnbouwwet. De Omgevingswet is echter steeds uitgesteld en naar verluidt komt het op 1 januari 2022 in werking.

Hier benadrukken we ook dat de omgevingsvisie het belangrijkste (enige) instrument van de wet is voor het neerzetten van richting. De provincie kan dan een plek veroveren in de regie van de Noordzee en kust door een visie te bieden voor de gewenste situatie en dat te vertalen in programma's door aan te geven hoe je van de huidige situatie naar de gewenste wilt komen; het beleid met instrumenten.

\subsubsection{Beleidsinstrumenten}

De provincie kan al voorsorteren op deze ontwikkeling. Het beleidsoverzicht van Oude Elferink (2020) kan als uitgangspunt dienen voor beter inzicht in het huidige beleid en van daaruit kunnen de huidige bevoegdheden worden geïdentificeerd en besproken. Een overzicht van bevoegdheden en ook rollen is een wens van de stakeholders om tot nieuwe initiatieven te komen.

In Sectie 5.4 worden scenario-specifieke accenten voor de governance van de Noordzee en de kust uitgewerkt, met meer over beleidsinstrumenten. Het gaat om het ruimtelijk beslag van de Noordzee, waaronder de gevolgen van medegebruik van energie-/windmolenparken, nieuwe nederzettingen voor dienstverlening en productie van voedsel, natuur, energie, recreatie etc. Eerst kijken we echter meer specifiek naar het lerende vermogen van het netwerk van de provincie.

\subsection{Het lerende vermogen van het netwerk van de Provincie Zuid-Holland}

De uitdaging van een netwerkorganisatie is afbakening, onderhoud en efficiënt gebruik van het netwerk. Een belangrijk kenmerk van het hierboven gepresenteerde stromenmodel is de dynamiek: het is geen momentopname (zoals het huidig onderzoek). Omdat context en de dynamiek van het externe PZH-netwerk voortdurend verandert, heeft het $\mathrm{PZH}$-uitwisseling van kwalitatief goede kennis nodig om adequaat te kunnen reageren op nieuwe omstandigheden. Er ontstaat een 'window of opportunity' als $\mathrm{PZH}$-medewerkers beschikken over de capaciteit om kennis en informatie om te zetten in formulering, herziening en toepassing van beleid. En om netwerkpartners te ondersteunen in het realiseren van de eigen doelstellingen. Dat vraagt om een duidelijke PZH-netwerkstrategie en om investering in het lerende vermogen van het netwerk. In deze sectie geven we duiding aan de randvoorwaarden voor een lerend (extern) netwerk van de $\mathrm{PZH}$.

De basisstructuur van het netwerk bepaalt de vorm en inhoud van de drie onderscheiden stromen (maatschappelijk-politieke stromen; probleemstroom; oplossingsstroom; zie Figuur 28). Het zijn de gestelde prioriteiten met betrekking tot kust en Noordzee die bepalen hoe groot het netwerk is waarin geïnvesteerd gaat worden (de diameter van het 'linkerwiel' in Figuur 28), en hoe de parten daarin zich in omvang tot elkaar verhouden. Bij kwalitatief hoogwaardige uitwisseling met het externe netwerk (de drie stromen in Figuur 28) beschikt de PZH over een goede 'thermometer' wat betreft de maatschappelijk-politieke omgeving (van lokaal tot internationaal); is ze ontvankelijk en bereikbaar voor de problemen die zich bij maatschappelijke vraagstukken voordoen; en weet ze de juiste kennis te mobiliseren om snel en adequaat uitdagingen in kansen om te zetten. Goed inspelen op kennis van buiten kan alleen als de $\mathrm{PZH}$-visie duidelijke doelen, handelsperspectieven en beslissingskader biedt. Al deze elementen bepalen het lerend vermogen van een netwerk.

\subsubsection{Proactief handelen op context vergt benutten van diversiteit van kennis}

Voor een goed aanpassingsvermogen (adaptability) van een netwerk is lerend vermogen nodig. Het maakt een systeem wendbaar. Een netwerk met goed functionerende kennisstromen heeft het vermogen om kennis op te nemen (absorptievermogen), te verspreiden (diffusiecapaciteit), te 
ontwikkelen (generatievermogen) en te benutten (exploitatievermogen). Het zijn daarmee belangrijke componenten van een netwerkstrategie.

In de voorbereiding van de workshops kreeg het projectteam moeilijk toegang tot het interne en externe netwerk van de PZH: we werden intern vaak doorverwezen en konden het interne en externe netwerkkapitaal van de PZH-team in geringe mate benutten. Vanuit de deelnemers aan de workshops was er ook herhaaldelijk een roep om meer toegankelijkheid tot de PZH en transparantie in gestelde doeleinden.

In de uitwisseling van kennis over context, problemen en oplossingen (de drie stromen in Figuur 28) onderscheiden we vier verschillende soorten kennis die in een netwerk uitgewisseld worden, en die het lerend vermogen van een netwerk bepalen (Sprenger \& ten Have, 1996): subjectkennis; handelingskennis; methodekennis; en sociaal-culturele kennis. Deze zullen we illustreren aan de hand van de dynamiek in de workshops.

\section{Subjectkennis}

In de workshopdiscussies was er bij de deelnemers, waaronder PZH zelf, een sterke focus op subjectkennis en overdracht van informatie aan het projectteam ten behoeve van verwerking tot een eindproduct, waaraan PZH de eigen handelingsperspectieven wil ontlenen. Onder subjectkennis verstaan we de specialistische kennis, die vergelijkbaar is met professionele expertise en vraagt om continue actualisering. Uit de dynamiek tijdens de workshops was af te leiden dat er nog geen eenduidigheid of voldoende bekendheid is wat betreft de perspectieven en aanwezige kennis: noch tussen de deelnemers en $\mathrm{PZH}$; noch tussen de PZH-medewerkers onderling. Omdat de workshops werden gezien als vehikel voor het aanleveren van kennis aan het project, werd de kans om te werken aan verdieping van de netwerkrelaties onderbenut, bijvoorbeeld door elkaar te bevragen over perspectieven en ervaringen uit de praktijk.

\section{Handelingskennis}

Het zijn vooral de genodigde deelnemers aan de workshops die handelingskennis inbrachten: de kennis die nodig is om beleid en kansen om te zetten in daden. Bij het handelen wordt zichtbaar of beleid goed werkbaar is en leidt tot gewenste resultaten. Handelingskennis is alleen door ervaring en oefening aan te leren; en direct gerelateerd aan een specifieke context. Deelnemers vroegen om meer uitwisseling van handelingskennis door te vragen om een 'proactieve houding' van PZH. Dit kwam met name van de kleinere partijen met minder onderhandelingsmacht, (de workshops zelf werden als proactief initiatief gewaardeerd). Als voorbeeld gaf een gemeente aan dat deelname aan platforms (bijvoorbeeld het Bestuurlijk Platform Visserij) vaak met name op papier bestaat terwijl er in de praktijk weinig contact is. Er werd aangegeven dat met meer contact de PZH beter zou weten wat er speelt (in dit voorbeeld de veelheid van vormen van visserij en belangen). Dat zou meer openingen geven op het moment dat er gesproken wordt van transitie (in dit voorbeeld van de visserij). 'Om het gesprek te voeren is dan handig om de lijntjes kort te hebben als gemeente.' Meer ambitie voor de visserij vraagt echter meer provinciale regie op de visserij en de ambitie van de Provincie dient dan te verschuiven van een beperkte, passieve rol naar een meer actieve rol.

\section{Methodekennis}

Aan PZH werd gevraagd om verbinder en stimulator te zijn in het creëren van experimenteerruimte om 'ontwerpkracht beter in te zetten' en er zodoende 'achter te komen wat kan en niet kan, wat mogelijk is in gezamenlijkheid'. Methodekennis bestaat uit het kunnen gebruiken van instrumenten en methoden die nodig zijn om subjectkennis te gebruiken zodat deze operationeel wordt. Bijvoorbeeld projectmanagement, kennis van ontwerpprocessen en monitoring. Deze methoden helpen ook bij het snel verwerven van nieuwe subjectkennis: leren te leren. Hier werden de Quadruple Helix en de Groene Cirkels genoemd als voorbeeld van hoe er rond de Noordzee gewerkt kan worden en er bijvoorbeeld is gewerkt rond de Zandmotor. Ook Campus@Sea is hierbij genoemd.

\section{Sociaal-culturele kennis}

Deelnemers noemden het belang van goede communicatie en bewustwording om ook de 'tegenliggers' oftewel de 'niet-willenden' te bereiken en mee te nemen in het proces. Een goed netwerk beschikt over sociale kennis waarmee partijen verschillen kunnen overbruggen om elkaar in het dagelijkse 
werk te ondersteunen en te coachen. Dat vraagt om communicatieve vaardigheden (dialoog; onderhandeling) en oog voor noodzaak en wederkerigheid in de uitwisseling van kennis. Onder deze categorie is ook culturele kennis te vatten. Bijvoorbeeld het herkennen dat taal een cultuurdrager is en dus iets zegt over achterliggende perspectieven en waarden. Taal kan ook een belemmering vormen (jargon). Sociaal-cultureel omvat het bewustzijn van mogelijke verschillen in achtergrond en culturele waarden; en een open houding die bijdraagt aan het respect voor sociaal-culturele waarden. Vertrouwen is belangrijk in een netwerk en bepaalt de kwaliteit van de uitwisseling. Het directe contact met PZH in de workshops werd door de deelnemers gewaardeerd. Deelnemers noemden de reeds bestaande stakeholder platforms waarvan $\mathrm{PZH}$ (beter) gebruik kan maken. De beperkingen van het uitsluitend digitaal kunnen samenkomen en -werken gaf beperkingen aan de uitwisseling. De logistiek-technische problemen die zich bij de start van de workshops hebben voorgedaan, hebben het geduld van de deelnemers zonder twijfel op de proef gesteld. Desondanks was er sprake van positieve energie, betrokkenheid en een zekere informaliteit van de deelnemers tijdens de workshops; in de eigen bijdragen en tijdens de groepsdiscussies. Dat is een sociaal kapitaal dat PZH kan uitbouwen in een netwerkstrategie. Deelnemers gaven daarbij zelf aan dat er in een vervolgtraject in de strategieën ook ruimte ingericht moet zijn om de nolens-volens (i.e. de partijen die niet aan overlegstructuren deelnemen) actief te betrekken in het transitieproces. Hier wijzen we op de behoefte uitgesproken door de respondenten om een doorlopende workshop in te zetten voor de ontwikkeling en interpretatie van beleid. Ook is het van belang een track-and-trace systeem op te zetten om voortgang en effectiviteit van beleid te evalueren en blinde vlekken te identificeren. Dit draagt bij aan een meer proactieve Provincie die vanaf een eigen positie veel meer midden in de samenleving staat en ook beter kan inspelen op veranderingen. Samenwerking is het devies bij een versterkte inzet van de Provincie in de ontwikkeling van beleid.

Samenvattend brengen alle actoren in het PZH-netwerk subject-, handelings-, methode- en sociaalculturele kennis in. Hierbij kan nog aangemerkt worden dat via de zwakke schakels, die verschillende netwerken verbinden, vooral nieuwe informatie gecombineerd wordt en daarmee innovatie stimuleren, terwijl de sterke schakels, daar waar veel vertrouwen bestaat in de relatie, nodig zijn voor de samenwerking om innovatie ook door te voeren in de praktijk. De bronnen van kennis en informatie uit het externe netwerk van de PZH variëren. Zo zullen wetenschappers en adviseurs vooral subjectkennis aanbrengen, terwijl in de maatschappelijk-politieke stroom de sociale media veel sociaal-culturele kennis zal bevatten (zie Figuur 31).

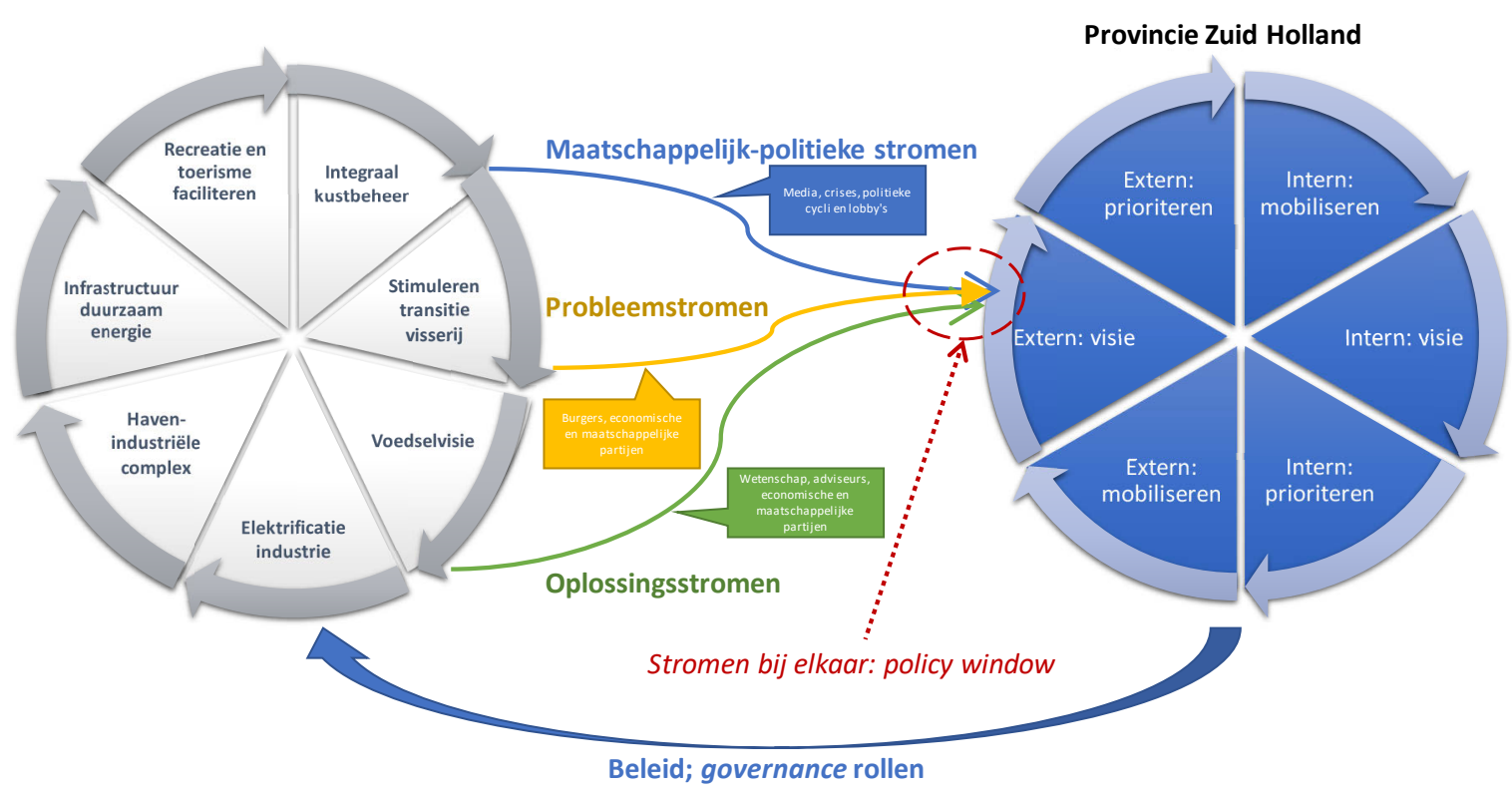

Figuur 31 Stromenmodel met opgaven (linker wiel), planning (rechter wiel) en beleid voor de Provincie Zuid-Holland 
Voor het versterken van het lerend vermogen van de netwerken met betrekking tot de wisselwerking tussen Noordzee en Zuid-Hollandse kust, kan de PZH bouwen op reeds aanwezig kapitaal:

- Kennisclusters bestaande uit bedrijven en wetenschap die gezamenlijk werken aan innovatie en maatschappelijke vraagstukken. Deelnemers noemden uitbreiding van de Groene Cirkels.

- Praktijknetwerken zoals de Community of Practice Noordzee en Nexus. Dit zijn kennisdragers en kunnen bijdragen aan het lerend vermogen van het $\mathrm{PZH}$-netwerk.

- PZH-netwerken, bijvoorbeeld voor het faciliteren van financiering van grote projecten door het Rijk of de Europese Unie.

- Kennis in de netwerken die benut kan worden. Een belangrijke gemene deler in de workshops was de betrokkenheid van de deelnemers; oog voor het 'algemeen belang' en de bereidheid om bij te dragen aan het optimaliseren van $\mathrm{PZH}$-beleid en rol.

Een groter lerend vermogen (intern ontsluiten van kennisstroom) van de PZH zal bijdragen aan de weerbaarheid en vitaliteit van de provinciale netwerken en diens capaciteit om de kansen van de Noordzee te benutten. De optimale balans in de soorten kennis en uitwisseling ervan zal op netwerkniveau binnen en buiten de PZH verschillen. Hoe groter het netwerk, hoe meer investering in sociale kennis nodig is. In beide gevallen zal helder moeten zijn wie welke verantwoordelijkheid draagt in de ontwikkeling en sturing van kennisstromen binnen de relevante netwerken.

\subsubsection{Organisatie van het interne en externe netwerk}

We hebben aangegeven dat de weerbaarheid en wendbaarheid van de Provincie Zuid-Holland om in te spelen op kansen die zich voordoen rondom de Noordzee afhangen van een goede organisatie van het interne en externe netwerk van de PZH en de kennisuitwisseling tussen de actoren. Daarbij hebben we drie stromen onderscheiden die gecombineerd de PZH de kans ('window of opportunity') biedt om beleid te (re-) formuleren en toe te passen.

De deelnemers aan de workshops hebben vier kernpunten c.q. behoeften ingebracht met betrekking tot de handelsperspectieven van de PZH in het netwerk 'Kansen van de Noordzee':

- Integratie

Behoefte aan formuleren van eigen visie door $\mathrm{PZH}$, het organiseren van cohesie tussen de beheerplannen van kustgebieden door de terreinbeheerders en, tot slot, bestuurlijke integratie. Voor de burger (met ideeën) moet de bestuurlijke organisatie overzichtelijker. Verder wordt gevraagd om evaluatie van de samenhang tussen ontwikkelingen (cumulatieve beoordeling) op Noordzee en aan de kust.

- Samenwerking

Behoefte aan heldere definiëring van bevoegdheden, waarbij mede-eigenaarschap de vrijblijvendheid vervangt. Met samenwerking zoekt men bestuurlijke ontschotting en tegengaan van (financiële) verkokering tussen netwerkpartijen. Het belang van het organiseren van Quadruple Helix (samenwerking) is genoemd. Dit vraagt om verdere samenwerking tussen kustprovincies. PZH geeft aan dat bestuurlijke samenwerking langzaam groeiende is, bijvoorbeeld tussen kustprovincies, het havenbedrijf en de Gemeente Rotterdam met betrekking tot aanlandingspunten.

- Zorg en vertegenwoordiging

Behoefte aan het borgen van leefbaarheid van omgeving en vitaliteit van actoren die geen prioriteit hebben in beleid van het Rijk (bijvoorbeeld visserij). Zo ook de goede vertegenwoordiging van de Provincie in andere bestuursorganen, bijvoorbeeld van het Rijk. Dit heeft betrekking op de principes van goed openbaar bestuur: het zorgdragen voor sociale gelijkheid (kosten; baten; evenredigheid).

\section{- Coördinatie}

Behoefte aan duidelijkheid over welk bestuursniveau welke zaken het beste oppakt (beleid en bevoegdheden). Er wordt aangegeven dat men de veelheid aan bestaand beleid en bevoegdheden niet helder heeft: 'Ook hierover moeten we praten'. Er is meer samenwerking nodig, waar de partijen samen op zoek gaan naar goede praktijken (best practices), bijvoorbeeld.

In de workshops werd ook gezegd dat de prioriteiten voor de provincie Zuid-Holland daar liggen waar de wederzijdse afhankelijkheid van de nieuwe activiteiten op de Noordzee en op land het grootst is. Nieuwe ontwikkelingen op zee dienen in bestaande systemen op land geïntegreerd te worden. Ook de kustveiligheid is als prioriteit genoemd, in samenhang met voedselzekerheid. Een voorbeeld zijn de 
windmolenparken op zee (genoemd in workshop 3). De economische haalbaarheid van windmolenparken op zee hangt direct af van aanlandingspunten aan de kust. De vitaliteit van beide wordt bepaald door de vraag, waarvoor voldoende elektrificatie van industrie en de bebouwde omgeving noodzakelijk is. De vraag zal gestimuleerd moeten worden, gebeurt dit niet, dan blijft de maatschappelijke prijs van stroom te hoog. Tegelijkertijd noopt de energietransitie in de vorm van windmolenparken tot een transitie van de visserij omdat het ruimtebeslag van windmolenparken (een omslag naar passieve visserij om meervoudig gebruik van de zee mogelijk te maken). Dit heeft sociaaleconomische en culturele gevolgen op de visserijgemeenschappen. In de workshop gaf de PZH aan dat het de eigen taak is om het Rijk goede informatie te verschaffen over de gevolgen op het land van wat er op de Noordzee gebeurt.

\subsection{Wat en hoe met wie: Een blik op de toekomst}

Voor de weg naar toekomst zien we een route die gebaseerd is op een meer bewuste en gerichte aanpak voor de Noordzee. Het gaat om zowel een interne als externe aanpak rond: i) het mobiliseren en richting geven; ii) capaciteit bouwen; en iii) middelen/resources genereren. We zien de grootste kansen in een driedelig perspectiefverschuiving:

- Op zee

De zee wordt voor het eerst fysiek ingedeeld. Binnen de windmolengebieden komen occupatieprocessen op gang. Het bedenken en uitvoeren van die occupatie is een grote kans.

- Aan de kust

Binnen afzienbare tijd is de zandevenwichtssituatie aan de kust bereikt (Zuid-Hollands deel). De kans ligt in een perspectiefverschuiving van noodzakelijk ingrijpen naar gewenst ingrijpen. Het actief vormgeven van de kust, vanuit allerlei doelen, kan de standaard worden. Dan worden de gebruiksmogelijkheden veel groter.

- Rond de haven

De Rotterdamse haven ligt deels in de zee. De kans ligt in de perspectiefverschuiving om dat terrein (ook) als 'bedrijventerrein aan de rand van de zee' te zien. Uiteraard vanuit de achtergrond dat de zee een nieuwe occupatie krijgt.

Voor elk van de Noordzee scenario's voor 2030/2050 (zie Hoofdstuk 2) zijn er specifieke accenten te leggen wat betreft beleid (zie Tabel 10).

Tabel 10 Specifieke opgaven, rollen \& verantwoordelijkheden en beleidsinstrumenten per Noordzeescenario voor 2030/2050

\begin{tabular}{|c|c|c|c|}
\hline & Opgaven & Rollen \& verantwoordelijkheden & Beleidsinstrumenten \\
\hline \multirow{4}{*}{ 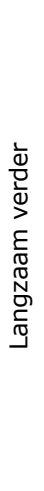 } & $\begin{array}{l}\text { 1. Stagnerende globalisatie en harde } \\
\text { Brexit vragen duurzaam } \\
\text { stimulering van de kusteconomie }\end{array}$ & 1. PZH-regie op de kusteconomie & $\begin{array}{l}\text { 1. Financieel support: een kust- en } \\
\text { zee versie van de huidige MIT- } \\
\text { subsidie (MKB Innovatiestimulering } \\
\text { Topsectoren Zuid-Holland) }\end{array}$ \\
\hline & $\begin{array}{l}\text { 2. Verzilting van landbouw } \\
\text { tegengaan: mitigatie en adaptatie }\end{array}$ & $\begin{array}{l}\text { 2. PZH-coördinatie en co-creatie met } \\
\text { Waterschappen, RWS, } \\
\text { drinkwaterbedrijven, gemeenten en } \\
\text { landbouwsector }\end{array}$ & $\begin{array}{l}\text { 2. Ruimtelijke ingrepen in } \\
\text { watermanagement en agronomisch } \\
\text { onderzoek }\end{array}$ \\
\hline & $\begin{array}{l}\text { 3. Zeespiegelstijging vraagt statisch } \\
\text { en dynamisch kustbeheer }\end{array}$ & $\begin{array}{l}\text { 3. RWS, PZH en overige } \\
\text { kustprovincies }\end{array}$ & $\begin{array}{l}\text { 3. Ruimtelijke ingrepen in kuststrook } \\
\text { en management }\end{array}$ \\
\hline & $\begin{array}{l}\text { 4. Verbeteren kwaliteit toerisme en } \\
\text { recreatie vraagt faciliteren en } \\
\text { steunen van de branches }\end{array}$ & $\begin{array}{l}\text { 4. Toerisme Zuid-Holland, PZH met de } \\
\text { gemeenten }\end{array}$ & $\begin{array}{l}\text { 4. Ontwikkeling organisatie en } \\
\text { capaciteit; economisch stimuleren; } \\
\text { vestigingsklimaat }\end{array}$ \\
\hline
\end{tabular}


Opgaven investeringen en opschaling

2. WOZ-aanlanding, CCS en olie \& gas afbouw vraagt transformatie haven industriële complex

3. Nederlands natuurnetwerk vraagt provincie-overstijgend natuurbeheer

4. Aquacultuurontwikkelingen vragen innovatie

5. Dynamisch kustbeheer vraagt integratie met natuur en toerisme $\&$ recreatie

1. Globalisatie en akkoord UK vragen in goede banen leiden van economische groei

2. WOZ-aanlanding, CCS, olie \& gas afbouw en toename scheepvaart vragen transformatie en uitbreiding haven industriële complex

3. Visserij-en

aquacultuurontwikkelingen vragen transformatie en innovatie

4. Zeespiegelstijging vraagt statisch en dynamisch kustbeheer

5. Verbeteren kwaliteit kusttoerisme/recreatie vraagt faciliteren en steunen van de branches

1. Circulaire economie en $\mathrm{CO} 2$ neutraal stimuleren

1. PZH-regie: met Rijk en Regio

PZH: Eerst intern steun opbouwen
voor de klimaatopgave binnen andere opgaven

5. PZH: coalitie bouwen met rijk en gemeenten, en economische sectoren partners van de Groei Agenda. overheden

3. PZH: zowel intern als extern werken aan een taakgerichte agendabouw

4. Co-creatie rijk en economische sectoren voor de opgave

1. Eigen regie + co-innoveren

3. $\mathrm{PZH}$ : Visieontwikkeling intern en
1. Groene groei vraagt groene

Beleidsinstrumenten

PZH met rijk en regio, en de vele

PZH: Coördineren met andere

5. PZH: Eigen visie op en intern steun

2. Co-regie Haven-industriële complex ook in relatie tot externe netwerk en olie $\&$ gas afbouw vraagt transformatie haven industriële complex

3. Internationaal natuurnetwerk vraagt provincie- en land overstijgend natuurbeheer

4. Visserij en aquacultuur ontwikkelingen vragen transformatie en innovatie

5. Dynamisch kustbeheer vraagt integratie met natuur en toerisme $\&$ recreatie Agenda Pilot Facility'. integratie in 'Ontwerp Holland' innovatieregelingen,

5. Inzetten op het 'Ontwerp Industrieel Complex'. innovatieregelingen Agenda en het Omgevingsprogramma en natuur economie en klimaat (Groene Cirkels; ACCEZ) Industrieel Complex'.
3. EU, Rijk, Provincies, Natuurorganisaties en landeigenaren

4. PZH: zelf prioriteiten stellen, met het Rijk i.s.m. sectoren

5. Rijk, RWS, Provincies, Waterschappen, Haven van Rotterdam, Natuurorganisaties, drinkwaterbedrijven en gemeentes

1. Kust en zee includeren in de Groei

2. Via het Energie Programma 'Schone energie voor iedereen', de kraamkamer 'Versnellingshuis Energietransitie Haven- en Industrieel Complex', en de 'Biotech Campus' en de 'Bioprocess

3. Inzetten op Natuurnetwerk NL, via Omgevingsverordening en Omgevingsprogramma Zuid-

4. Inzet op eigen visie en aansluiting op EU Blue Growth, inzet structuurfondsen, MIT-subsidie, Omgevingsprogramma ZuidHolland', met Natuurnetwerk NL

1. Dialoog: kansen in kaart brengen; planning met de Groei Agenda

2. Intern mobiliseren en dan naar buiten met eigen ambitie en aanpak via het Energie Programma 'Schone energie voor iedereen' en de kraamkamer 'Versnellingshuis Energietransitie Haven- en

3. Inzet op eigen visie en aansluiting op EU Blue Growth, inzet structuurfondsen, MIT-subsidie,

4. Klimaat integreren in de Groel

5. Een verbindend verhaal voor (en visie op) toerisme, recreatie, cultuur (historie), landschap, water

1. Strategie $\mathrm{PZH}$ op circulaire operationaliseren en prioriteiten stellen; doorzetten kenniseconomie

2. Intern mobiliseren en dan naar buiten met eigen ambitie en aanpak via het Energie Programma 'Schone energie voor iedereen' en de kraamkamer 'Versnellingshuis Energietransitie Haven- en

3. Ruimtelijke coördinatie en management provinciaal, nationaal en internationaal natuurnetwerk

4. Programma voor subsidie, stimulatie en innovatie

5. Integrale ruimtelijke, economische en bestuurlijke oplossingen Afstemmen ruimtelijk kust, natuur, toerisme \& recreatie en infrastructuurbeleid 
Onafhankelijk van de Noordzeescenario's voor 2030/2050 (zie Hoofdstuk 2) zijn er overkoepelende accenten te leggen wat betreft beleid (zie Tabel 11). Hierbij ligt de nadruk op samenhang/integratie en een includerende aanpak gebaseerd op dialoog, die nodig is voor de toekomst.

Het is voor beleidsmakers erg verleidelijk om programmatische plannen te maken met strak omlijnde doelen en inhoud met een tijdplanning. Het is echter hier belangrijk om te beseffen dat de aanbevelingen onderdeel zijn van een transitieproces en dat het van groot belang is om leerprocessen levend te houden. Ambitie geeft daar richting aan, maar het is vooral van belang om in gesprek te blijven, ook intern, en samen zoeken naar spanningen en blokkades en dan kijken hoe de oplossingen passen in de context waar ze zich bevinden. Gezamenlijke monitoring en evaluatie is van groot belang. Uiteindelijk is een gedeeld gevoel van eigenaarschap ontwikkelen een cruciaal onderdeel, intern maar ook extern. Daarbij is het vieren van kleine successen ook belangrijk.

Tabel 11 Overkoepelende opgaven, rollen \& verantwoordelijkheden en beleidsinstrumenten

\begin{tabular}{ll} 
Opgaven & Overkoepelend \\
\hline Beleidsinstrumenten & $\begin{array}{l}\text { 1. Dynamisch samenhangend en integraal kustbeheer } \\
\text { 2. Workshops met stakeholders over beleid en maatschappij }\end{array}$ \\
\hline Rollen \& verantwoordelijkheden & $\begin{array}{l}\text { 1. Programma met juridische, economische en communicatieve inzet } \\
\text { 2. Communicatie en organisatie van dialoog }\end{array}$ \\
& $\begin{array}{l}\text { 2. PZH in de regie met andere provincies en gemeenten } \\
\text { 3. PZH organiseren, monitoren en evalueren, met anderen }\end{array}$ \\
\hline
\end{tabular}




\section{Conclusies en aanbevelingen}

\subsection{Conclusies}

De ontwikkelingen op de Noordzee bieden kansen om de economie in de Provincie Zuid-Holland te versterken en de ruimtelijke omgevingskwaliteit te verbeteren. Met dit onderzoek krijgt de Provincie Zuid-Holland een beter inzicht in de ontwikkelingen op en rond de Noordzee die de provinciale ambities kunnen beïnvloeden en vormen. Op basis van verwachte trends en ontwikkelingen op en rond de Noordzee en gerelateerde stakeholders' visies, ambities en kansen ontwikkelden we, uitgaande van de Noordzeescenario's ontwikkeld door PBL (2018, 2019), vier scenario's voor de toekomst voor de Provincie Zuid-Holland. Voor ieder van deze scenario's gaven wij inzicht in de verwachte economische en ruimtelijke impacts evenals een overzicht van de maatschappelijke opgaven, de mogelijke beleidsinstrumenten en de gerelateerde rollen \& verantwoordelijkheden die deze scenario's met zich meebrengen. Deze scenario's vormen de basis voor de definitie van no-regret beleidsaanbevelingen rond ontwikkelingen en kansen gerelateerd aan activiteiten op zee, aan de kust en in de haven. Hiermee agenderen wij onderwerpen voor het ontwikkelen van een samenhangend (toekomstig) economische en ruimtelijke omgevingsbeleid van de Provincie Zuid-Holland.

\subsection{Aanbevelingen}

\subsubsection{Beleidsproces: investeer in interne en externe regie}

Er is een grote bestuurlijke drukte op de Noordzee en aan de Noordzeekust. Juist in deze drukte is er vraag naar en ruimte voor meer interne en externe regie van de Provincie (zie 5.1). Ten eerste vraagt de kluwen van belangen en overheidslagen om coördinatie in interne en externe beleidsuitvoering - de Provincie heeft hierin een belangrijke rol, zoals bijvoorbeeld vastgelegd in het Nationale Visie Kust en het Kustpact. Ten tweede kan de Provincie ontzorgen waar inzet nodig is voor zaken en mensen die buiten de beleidskaders vallen. Ten derde kan de Provincie concreet beleid co-creëren via continue interactie met stakeholders. Tot slot, kan de Provincie co-innoveren door een snelweg voor goede plannen te faciliteren. Voor al deze opgaven is het van groot belang dat de Provincie intern de al ingezette koers nadrukkelijker en meer expliciet combineert met de capaciteit en ook de verdere ontwikkeling van de krachten die er al zijn of die in ontwikkeling zijn binnen de Provincie (zie 5.1, 5.2 en 5.3).

We wijzen ook nadrukkelijk op het signaal van stakeholders dat er behoefte is aan een doorlopende 'workshop' over de ontwikkelingen in beleid en maatschappij (zie 5.2.2). Hiermee kan ook gereedschap in stelling worden gebracht om de sterke en zwakke punten van beleid in kaart te brengen en blinde vlekken te identificeren via een track-and-trace systeem (zie 5.3). Dat draagt bij een proactieve Provincie die midden in de samenleving staat.

\subsubsection{Investeer in de kust}

\subsubsection{Versterk duurzaam kusttoerisme om de kwaliteit van de leefomgeving te verbeteren en werkgelegenheid te vergroten}

\section{Wat}

Toerisme is een economische activiteit waarbij investeringen sector overstijgende baten genereren (zie 3.1). Bij het versterken van duurzaam kusttoerisme staan multifunctionaliteit van het kustfundament en de kuststrook centraal (zie 4.1.2). Dit omvat het creëren van een groene en duurzame leefomgeving voor bewoners, de verhoging van het economisch potentieel (inkomen en banen), de weerbaarheid tegen klimaatschokken (zie 'Versterk met dynamisch kustbeheer de 
veiligheid, ruimtelijke kwaliteit en multifunctionaliteit van het kustgebied') en het behoud van biodiversiteit (zie 'Investeer in nationale en internationale natuurnetwerken'). Ecotoerisme en recreatie zijn belangrijke elementen in de strategische gebiedsplanning bij een toenemende druk op het duingebied in de Metropool Rotterdam-Den Haag en daarbuiten. Door deze functies te waarborgen kan dit samengaan met innovatie in de kuststrook om ruimtelijke kwaliteit te vergroten.

\section{Waarom}

Toerisme en recreatie verbinden natuurbeleving en -beheer, cultuur, sport en het welzijn van de bewoners in de Metropool Rotterdam-Den Haag en daarbuiten. Toerisme is een groeiende sector, waar kusttoerisme een groot deel van uitmaakt (zie 3.1). Er is meer vraag naar jaarrond recreatievoorzieningen en goede, duurzame logistieke aansluiting met het achterland om toerisme te spreiden (zie 2, 3.2 en 4.2). Dat is nodig om de kosten-baten voor bewoners in balans te houden. De vergroting van de capaciteit en de toename in kwaliteit van het kusttoerisme, zowel onshore, nearshore als offshore, leidt tot een toename van toerisme gerelateerd aan recreatie, ecotoerisme en wind op zee (zie 3.2). Deze ontwikkelingen leiden tot een sterke toename van het aantal banen en het ruimtebeslag van de recreatiesector in de Provincie Zuid-Holland.

\section{Hoe}

Creëer een gezamenlijk toerisme en recreatie strategie met gemeenten, de provincies Zeeland en Noord-Holland en het Rijk, met synergie waar mogelijk en differentiatie waar nodig om aanbod en identiteit te borgen (zie 5.4). Dit vergt werk aan de koers die de Provincie wil varen en die dient weer sterker gekoppeld te worden aan (het werken aan) de slagvaardigheid van de Provincie (zie 5.2.1, 5.2.2 en 5.3). Richt innovatie van de kustlijn op het verhogen van de opvangcapaciteit voor dagrecreatie (zie 0). Behoud de huidige verdeling in noord-zuid richting tussen intensieve en extensieve gebieden, ten behoeve van de balans tussen meervoudige functies van het kustgebied (recreatie, water- en kustveiligheid, leefomgeving, biodiversiteit en klimaatadaptatie; zie 4.1.2). Houdt nieuwe wegen, parkeerplaatsen en gebouwen weg van de kust en versterk aldus de kustbeleving. Zie strand en de eerste duinstrook als een belevingszone rond natuurlijke processen. Maak de primaire zeewering beplantingsvrij waar dat veilig is en beperk toegang van de eerste duinstrook voor dagrecreanten niet, maar leg deze beperkingen daar net achter. Verbindt kustrecreatie met behoud van het historisch landschap en het cultuuraanbod van het (stedelijke) achterland; zoals de erfgoedlijnen en stedelijke/regionale musea.

\subsubsection{Versterk met dynamisch kustbeheer de veiligheid, ruimtelijke kwaliteit en multifunctionaliteit van het kustgebied}

\section{Wat}

Kennis over kustbescherming, ecologie en klimaat wordt door Zuid-Hollandse bedrijven en instituten wereldwijd te gelde gemaakt. De ervaringen met de Maasvlaktes en de Zandmotor spelen hierin ook een belangrijke rol. Het verder ontwikkelen van dynamisch kustbeheer komt de veiligheid en ruimtelijke kwaliteit in de Provincie ten goede, draagt bij aan de weerbaarheid van de kust en het achterland en versterkt bovendien de kennispositie (zie 4.1.2). Beschouw kust morfologische processen als planbare processen, ook al is de planhorizon soms 50 jaar of meer, met behoud van het maximale adaptieve vermogen van het systeem.

\section{Waarom}

De 'lead time' voor aanpassingen aan klimaatverandering wordt steeds korter. Na 2050 kan de zeespiegel mogelijk snel en sterk stijgen (zie 4.1.2.2). Beperkte doelstellingen, zoals focus op alleen kustveiligheid, leiden daarbij tot te beperkte oplossingen. Dynamisch kustbeheer is wat betreft kosten een vrijwel gelijkwaardig alternatief voor de traditionele harde kustbeschermingsmaatregelen, terwijl het meer baten biedt in de vorm van een verbetering in biodiversiteit en groei in capaciteit en kwaliteit van kusttoerisme (onshore; nearshore; zie 4.2). Dit leidt tot een toename van het aantal banen en het ruimtebeslag van de recreatiesector in de Provincie Zuid-Holland (zie 3.2.4).

\section{Hoe}

Zet als Provincie Zuid-Holland in op een verbreding van de doelstellingen evenals een ambitieuze agenda met heldere prioriteiten en taken. Groei toe naar een actief beheer van de zandrivier omdat 
die het fundament is voor de kust morfologische processen (zie 4.1.2). Koppel de huidige en gewenste toestand van de zandrivier aan de keuzes voor dynamiseren van de kust. Creëer ruimte voor adaptatie, verandering en genieten, analoog aan Ruimte voor de Rivier. Organiseer het kustbeheer over het hele kustprofiel, van de rand van het kustfundament tot de achterzijde van de duinen. Zorg voor zonering van ruimtelijke ontwikkelingen naar potentie voor multifunctionaliteit. Neem het voortouw met betrekking tot een gezamenlijk en gecoördineerd kustbeheer en -beleid over de gehele Noordzeekust door Rijk, Noordzeeprovincies en -gemeenten, met een taakgerichte aanpak voor de korte en lange termijn (zie 5.2.2). Neem in deze opgave van klimaatadaptatie niet alleen waterveiligheid en wateroverlast mee, maar ook hitte en droogte (stedelijk gebied achter kuststrook) en anticipeer op mogelijke versnelling van klimaatverandering door gebruik te maken van een lange tijdshorizon in gebiedsplanning. Maak keuzes voor een regionale klimaatadaptatiestrategie (waar is regionale sturing nodig en wat kan lokaal worden opgepakt) en wissel ervaringen uit over een meer decentrale regionale maritieme ruimtelijke planning met andere EU-landen (zie bijvoorbeeld Zweden ${ }^{9}$ ).

\subsubsection{Investeer in nationale en internationale natuurnetwerken}

\section{Wat}

Het kustgebied wordt gekenmerkt door verschillende ecosystemen, grote biodiversiteit en recreatiemogelijkheden (zie 4.1.2.6). Het creëren en koppelen van mariene, kust en terrestrische natuurgebieden biedt mogelijkheden voor groei in biodiversiteit. Dit kan nog eens versterkt worden als deze worden gekoppeld aan natuurgebieden in andere provincies (met name Zeeland en NoordHolland) en landen (met name België en Duitsland). Een krachtige samenwerking in natuurbeheer in de kustgebieden biedt nieuwe kansen om een sterkere koppeling te maken tussen het verbeteren van de biodiversiteit, de kwaliteit van het kusttoerisme en benutting van de natuur (zie 4.1.2.5).

\section{Waarom}

De nieuwe Nationale Parken (in oprichting) Hollandse Duinen en NL Delta kunnen als springplank dienen voor meer samenhang en samenwerking voor de instandhouding of versterking van de ecosystemen in de complexe dynamiek tussen zee, kust en stad (zie 5.2). De Provincie kan op die manier beleidsdossiers als klimaatadaptatie, natuur, gezondheid en toerisme beter aan elkaar verbinden (zie 5.2.2). Een sterkere koppeling tussen het verbeteren van de biodiversiteit en een toename in de kwaliteit van het kusttoerisme, zowel onshore als nearshore, biedt kansen (zie 4.1.2.6). Samen met een vergroting van de capaciteit als gevolg van dynamisch kustbeheer (zie 'Versterk met dynamisch kustbeheer de veiligheid, ruimtelijke kwaliteit en multifunctionaliteit van het kustgebied'), leidt dit tot een toename van ecotoerisme en kustrecreatie (zie 0). Deze ontwikkelingen leiden tot een toename van het aantal banen en het ruimtebeslag van de recreatiesector in ZuidHolland (zie 3.2.4).

\section{Hoe}

Koppel onshore en nearshore natuurgebieden en maak verbinding met andere natuurgebieden in Nederland en daarbuiten, zodat een geïntegreerd natuurnetwerk ontstaat (zie 4.1.2.6). Gebruik daarbij ook dynamisch kustbeheer om koppeling tussen Noordzee kustprovincies te creëren (zie 4.1.2). Zet in op de uitvoeringsagenda's van de twee nationale parken in oprichting (Hollandse Duinen en NL Delta) door de reeds bestaande regionale duurzaamheidsnetwerken van de Nationale Parken te versterken (zie 5.2.2). Stimuleer nieuwe verdienmodellen voor de Nationale Parken door deze te verbinden met maatschappelijke vraagstukken, zoals klimaatadaptatie, gezondheid, en toerisme en recreatie (zie 5.4). Versterk de natuur over het gehele kustprofiel (van de rand van het kustfundament tot de achterzijde van de duinen) en koppel deze aan natuurbeheer in overige Noordzee kustprovincies en landen (zie 5.2.1, 5.2.2 en 5.4). Beschouw niet alleen de natuur en economische waarden van de Nationale Parken, maar ook het sociale draagvlak en de maatschappelijke impact.

\footnotetext{
9 Through the introduction of the marine spatial planning in Sweden, there are 65 municipalities where the planning responsibility overlaps between the municipality and the state in the territorial sea. Today, there are some 20 municipalities that have adopted comprehensive plans that encompass the entire territorial sea and present wellconceived municipal standpoints. Zie:

https://www. havochvatten.se/download/18.47bf2cd7163855d85cae2804/1529995894512/proposal-for-the-marinespatial-plan-skagerrak-and-kattegat.pdf
} 


\subsubsection{Benut het potentieel van windmolenvelden op zee}

\subsubsection{Zet in op medegebruik in windmolenvelden}

\section{Wat}

Windmolenvelden zullen een belangrijke plaats innemen op de Noordzee (zie 2). Dit leidt niet alleen tot het opwekken van duurzame energie en het creëren van groene banen, maar biedt ook mogelijkheden voor medegebruik binnen deze windmolenvelden en bijbehorende werkgelegenheid. Voorbeelden van medegebruik zijn: aqua-/maricultuur, passieve visserij, zonne-energie en recreatie (zie 4.2). Dit biedt mogelijkheden (zoals voor visserij; zie 'Stimuleer mogelijkheden voor de visserij in Zuid-Holland') en alternatieven (zoals olie \& gas; zie 'Stimuleer de duurzame energy hub') voor economische sectoren in de Provincie Zuid-Holland.

\section{Waarom}

Afhankelijk van de medegebruik activiteiten, verdienen windmolenvelden dichter bij de kust de voorkeur om management van activiteiten te faciliteren en transportkosten te drukken (zie 4.2). Ga ervan uit dat 'alles nieuw is' en dat perspectieven en ervaringen voortdurend veranderen. Er is dus behoefte te experimenteren, te testen en te leren, hetgeen gestimuleerd kan worden via kennisontwikkeling en testprojecten binnen bepaalde sectoren evenals via het leggen van verbindingen tussen sectoren (zie 5.2.2). Het ontwikkelen van en meeliften op onderzoek, investeringen en voorzieningen kan een motor zijn. De toename van de productie van windenergie op zee heeft een sterke toename van het aantal banen en het ruimtebeslag van de sector tot gevolg (zie 3.2). Dit compenseert deels de afname van banen in de olie \& gas sector (zie 'Stimuleer de duurzame energy hub'). Door doorwerking is er ook een lichte toename zichtbaar in andere sectoren, zoals offshore en aanleg van kabels en buizen. Medegebruik van deze windmolenvelden op zee leidt tot een kleine directe additionele groei in werkgelegenheid (zie 3.2) en, via doorwerking, een potentieel matige toename in andere sectoren (zoals ondersteunende diensten en verwerking van voedselproducten; zie 'Maak Zuid-Holland de zeewierprovincie van Nederland').

\section{Hoe}

Hoog inzetten op een ambitieus kenniscentrum, aangevuld met een versterking van beleidsinstrumenten, kan wind op zee opstuwen tot een omvangrijke nieuwe economie, ook via medegebruik in windmolenvelden (zie 5.2.2). De Provincie heeft niet veel directe zeggenschap over de omvang van de windmolenvelden op zee, maar er zijn volop kansen voor meer inzet op hoe medegebruik van de windmolenvelden uitgevoerd wordt. Dit medegebruik is nieuw en de rolverdeling is niet in beton gegoten maar juist in ontwikkeling. De Provincie kan processen faciliteren, begeleiden en coördineren. Zo kan de Provincie inzetten op de Lange Termijn Agenda (LTA) Omgevingsbeleid, een instrument van de Provinciale Staten, ter ondersteuning van hun agenderende rol in de ontwikkeling van het Omgevingsbeleid. De groeiende vraag naar duurzame energie- en voedselproductie biedt samen met de uitrol van windenergie op zee volop mogelijkheden om te experimenteren en vernieuwen. Vernieuwende samenwerking met tal van partijen zal de daadkracht versterken, denk aan overige kustprovincies, de North Sea Farmers, universiteiten/hoger onderwijs, de Gemeente Den Haag, Ministeries (bijvoorbeeld Infrastructuur en Waterstaat; Economische Zaken en Klimaat) en tal van samenwerkingsverbanden en private partijen (inclusief energiebedrijven, banken en reders).

\subsubsection{Stimuleer mogelijkheden voor de visserij in Zuid-Holland}

\section{Wat}

De havens van Scheveningen, Katwijk en Stellendam bieden vissers uit Zuid-Holland een poort naar de zee. De ontwikkeling van offshore windenergie zal vragen om een verandering van de huidige visserijpraktijken (zie 2). Het medegebruik van windmolenvelden voor aqua-/maricultuur en passieve visserij biedt een toekomstperspectief voor vissers evenals kansen voor de gerelateerde aanvoerende en verwerkende industrieën (zie 'Zet in op medegebruik in windmolenvelden').

\section{Waarom}

Om de afnemende omvang van de traditionele visserij te compenseren is het zaak innovatie van visserij en speciaal teelten in de windmolenvelden te stimuleren, niet alleen betreffende de productie 
maar ook wat betreft de verwerking en afzet. Dit vraagt onderzoek naar aqua-/maricultuur en passieve visserij, creatie van financieringsmogelijkheden en ontwikkeling van opleidingstrajecten (zie 5.4). Met name voor aqua-/maricultuur en in mindere mate voor passieve visserij, verdienen windmolenvelden dichter bij de kust de voorkeur om activiteiten te faciliteren en transportkosten te drukken (zie 4.2). De afname in de omvang van de traditionele visserij wordt deels of volledig gecompenseerd door aqua-/maricultuur en/of passieve visserij (zie 3.2). Netto heeft dit naar verwachting een beperkte netto invloed op de werkgelegenheid. Aangezien aqua-/maricultuur en/of passieve visserij relatief ruimte-intensiever zijn dan de traditionele visserij, neemt het totale ruimtebeslag van de sector wel toe.

\section{Hoe}

Meer ambitie voor de visserij vraagt meer provinciale regie op de visserij en de ambitie van de Provincie dient dan te verschuiven van een beperkte, passieve rol naar een meer actieve rol (zie 5.2.2 en 5.3). De Provincie stimuleert al innovaties in het MKB, ook voor de beroepsvisserij en de aanverwante bedrijvigheid. De Provincie werkt ook via het Visserij Innovatiecentrum ZuidwestNederland, faciliteert subsidies uit het Europees Visserijfonds, doet mee aan het Bestuurlijk Platform Visserij, zet zich in voor Europese lobbywerk, steunt de Campus@Sea Scheveningen, doet toekomstonderzoek voor Kansen van de Noordzee, werkt (samen met de Gemeente Den Haag) aan een fieldlab voor innovaties op de Noordzee aan de kust en in de haven en, tot slot, draagt bij aan de Groei Agenda. In aanvulling op 'Zet in op medegebruik in windmolenvelden' stellen we echter dat de visserij een beperkte rol speelt voor de provinciale beleidsagenda. De Strategische Agenda Kust noemt visserij één keer en dan in een historisch terugblik. We pleiten voor een sterkere nationale en internationale belangenbehartiging voor de visserij. De Provincie kent beleid voor visserij in gebiedsprogramma's en stimuleringsregelingen, maar vooral aan de kust en in de binnenwateren. Meer ambitie kan dus bouwen op tal van kansen, zoals die hier genoemd zijn.

\subsubsection{Maak Zuid-Holland de zeewierprovincie van Nederland}

\section{Wat}

De eerste ervaringen met offshore zeewierteelt worden opgedaan voor de kust van Zuid-Holland, en de in Den Haag gevestigde North Sea Farmers zijn een toonaangevende partij in de ontwikkeling van de keten. ${ }^{10}$ Het medegebruik van offshore windmolenvelden (zie 4.2), de haveninfrastructuur van Zuid-Holland (zie 4.1.3) en de bedrijven in het achterland bieden kansen om deze nieuwe sector te ondersteunen en te accommoderen in de Provincie.

\section{Waarom}

Teelt en gebruik van zeewier kan een bijdrage leveren aan het verduurzamen van het voedselsysteem, en biedt kansen voor een circulaire economie (zie 5.2.2). Meer ambitie voor zeewier is gewenst; er liggen tal van kansen om op te pakken. Zeewierteelt in windmolenvelden dichter bij de kust verdient de voorkeur om management van activiteiten te faciliteren en transportkosten te drukken (zie 4.2). Aanvoer en transport van materialen evenals afvoer en transport van producten vereisen havencapaciteit, zodat offshore zeewierproductie efficiënt kan plaatsvinden. Afhankelijk van de kwaliteit van het eindproduct (eiwitten, voeder of voedsel), moet de locatie van zeewieropslag en verwekende industrie niet alleen gekozen maar ook meer gefaciliteerd worden (zie 5.2.2). Meer inzet op medegebruik van windmolenvelden voor offshore zeewierteelt kan een kleine directe groei in werkgelegenheid betekenen en, via doorwerking, een potentieel groeifactor zijn voor andere sectoren (zie 3.2). Dit laatste gerelateerd aan ondersteunende diensten (denk aan aanvoer en transport van materialen en afvoer en transport van zeewier) en verwerking van zeewier in eiwit-, voeder- en voedselproducten (zie 'Zet in op medegebruik in windmolenvelden').

\section{Hoe}

Hier is van belang om op twee sporen in te zetten: i) het verbinden van voedsel/visserij, energie, ecologie en recreatie, en ii) realiseren van voorzieningen en infrastructuur er omheen (zie 5.2.2). De vele kansen en de grote onzekerheden over de toekomst van zeewier is daarbij een grote policy window voor de Provincie. Oormerken van windmolenvelden dicht bij de kust en het management van

\footnotetext{
${ }^{10}$ zie https://www. northseafarmers.org/
} 
de zeewiervelden zijn thema's die de Provincie kan faciliteren door het ruimtelijke aspect in samenhang te zien en investeringen in ruimtegebruik te legitimeren. De aanbeveling is om het werk rond de Noordzee-Nexus voort te zetten door in te zetten op verbindingen tussen water, voedsel en energie als een ecosysteem, door de grootschalige windmolenvelden op de Noordzee natuur inclusief te maken met zowel visserij als zeewierteelt en, tot slot, door de agenda's van energie te koppelen aan nutriënten, de eiwittransitie, korte ketens voor voedsel, natuur en de land-zee interactie (zie 5.3).

\subsubsection{Stimuleer natuurontwikkeling in de windmolenvelden}

\section{Wat}

Zet in op het stimuleren van natuurontwikkeling in de windmolenvelden, met aandacht voor adequate locaties en plaatsing van windmolenvelden, alternatieve habitats en mitigerende maatregelen. Investeringen om inzicht te krijgen in de economische effecten van natuurontwikkeling op zee kunnen worden gekoppeld aan kansen voor synergie (zie 4.1.1.3).

\section{Waarom}

Aandacht voor plaatsing van windmolenvelden is een kans om meer rekening te houden met plant- en diersoorten die deze gebieden gebruiken als verblijf-, trek- en/of voerplaats (zie 4.1.1.3 en 4.1.2.6). Zo kunnen, bijvoorbeeld, windmolenvelden in vogel trekroutes naar het Verenigd Koninkrijk worden vermeden. Het biedt ook kans om adequate mitigatiemaatregelen te nemen, zoals het stopzetten van windmolens tijdens de vogeltrek. Het creëren van habitats voor rif bouwers en vissoorten in windmolenvelden biedt kansen voor deze soortgroepen en draagt, potentieel, bij aan een groei in visstand. Het aanleggen van alternatieve habitats, zoals kunstmatige eilanden op zee die ook dienst kunnen doen voor zeezoogdieren en -vogels, bieden kansen voor natuurontwikkeling (zie 'Investeer in nationale en internationale natuurnetwerken'). De economische effecten kunnen positief zijn als, bijvoorbeeld, de visstand groeit als gevolg van grotere en verbeterde habitats.

\section{Hoe}

Voor de Provincie is geen algehele regierol beschikbaar maar wel een veel meer stimulerende en faciliterende rol door inzet op integrale oplossingen en het leggen van verbanden tussen beleidsagenda's (zoals energietransitie en natuurbeleid). De Provincie zou een sterkere rol kunnen opeisen door in te zetten op kansen voor natuur bij toekomstig medegebruik binnen de (geplande) windparken op het Nederlands Continentaal Plat (NCP; zie 5.2.1). Op de agenda staat de categorisering en zonering van innovatieve oplossingen (technologieën) die voor de toekomst gereed of operationeel worden gesteld, inclusief de relatie tussen windparken.

\subsubsection{Gebruik kracht Rotterdamse haven}

\subsubsection{Stimuleer de duurzame energy hub}

\section{Wat}

Het ruimtelijk beleid van de Provincie kan ingezet worden om de transitie naar duurzame energiebronnen en de verschuiving van olie \& gas naar elektriciteit en waterstof te stimuleren. Gekoppeld aan een groei in de scheepvaart en gerelateerde overslagcapaciteit, leidt dit tot een transitie in het havengebied (van olie \& gas naar elektriciteit en waterstof), het aantrekken van elektriciteit-intensieve sectoren en vereist dit een kleine toename in ruimtebeslag (zie 2). De kans op een sterke daling van de werkgelegenheid in en het ruimtebeslag van de olie \& gas sector maakt zo'n inzet noodzakelijk.

\section{Waarom}

Het Rotterdamse havengebied is uniek in Europa met zijn sterke technisch en sociale infrastructuur. Het havengebied speelt al een sleutelrol in de duurzame energievoorziening van de toekomst en dat maakt het geschikt voor meer inzet op de aanlanding van elektriciteit, gebruik van elektriciteit, transformatie van elektriciteit naar waterstof en/of opslag van waterstof (zie 4.2). De verwachte daling van de werkgelegenheid in en het ruimtebeslag van de olie \& gas sector kunnen grotendeels worden opgevangen door een duurzame energy hub gebaseerd op elektriciteit en waterstof (zie 3.2). De beschikbaarheid van waterstof biedt kansen het industrieel complex in de haven te verduurzamen. 
De verwachte groei in de scheepvaart leidt tot een lichte toename van de werkgelegenheid en het ruimtebeslag tot gevolg. Ook is er een stijging van de werkgelegenheid en het ruimtebeslag in de logistieke sector te verwachten.

\section{Hoe}

Samenwerking is het devies bij een versterkte inzet van de Provincie. De reeds ingezette versterking van de relatie met de Gemeente Rotterdam en de Haven van Rotterdam dient door de Provincie voortgezet te worden (zie 5.3). Vele ingrediënten zijn gereed voor verder gebruik, zoals de Biotech Campus en de Bioprocess Pilot Facility in Delft, kennisinstellingen, de Greenports en het haven industrieel complex met de grootste biobrandstoffen productiecapaciteit van Europa (zie 5.4). Als partner dient de Provincie Zuid-Holland kennisontwikkeling, innovatie en het ondernemerschap voor energie en bio grondstoffen op industriële schaal te stimuleren. De Groei Agenda zou een voertuig kunnen zijn, aangevuld met het stimuleren vanuit regionale innovatieprogramma's, de Actieagenda Technologische Industrie en het Human Capital Akkoord voor de menselijke kant van het verhaal. De Provincie doet dit in samenwerking met het Rijk, de Gemeente Rotterdam en Haven van Rotterdam, en samen met de twee laatsten dient de Provincie ook meer en gericht te lobbyen bij het Rijk.

\subsubsection{Benut de haven voor doorontwikkeling van offshore activiteiten}

\section{Wat}

Zet in op doorontwikkeling van de haven naar een 'bedrijventerrein aan de rand van de zee', met focus op het ruimtelijk faciliteren van de activiteiten op zee ( $\mathrm{CO} 2$ opslag; waterstof; windenergie) en met ruimte voor opslag van onderdelen voor deze activiteiten op zee en opslag/overslag van producten afkomstig van deze activiteiten op zee (zie 2). Satelliet havengebieden op zee kunnen, bovendien, worden gebruikt om onderdelen en producten dicht bij deze activiteiten op te slaan. De Maasvlaktes kunnen daarbij niet alleen dienstdoen als overslaggebied, maar ook als bedrijventerrein voor deze activiteiten op de Noordzee.

\section{Waarom}

Het Rotterdamse havengebied is uniek in Europa met zijn technisch en sociale infrastructuur. Het hergebruik van oude olie \& gas booreilanden voor CO2-opslag, het offshore produceren van waterstof en het faciliteren van activiteiten in windmolenvelden, creëert de behoefte voor aan- en afvoer van goederen en diensten (zie 4.2). Nu verkennen voor de toekomst is van groot belang. De economische effecten van deze basis voor offshore activiteiten in het Rotterdamse havengebied lijken voorlopig relatief klein (mede door de rol van andere Noordzeehavens), maar een stijging van de werkgelegenheid en het ruimtebeslag in de logistieke sector zal zichtbaar zijn (zie 3.2).

\section{Hoe}

In samenwerking met de Haven van Rotterdam kan de Provincie zwaarder inzetten op een innovatieprogramma voor activiteiten op zee (zie 5.4). Koppel dit aan de doorontwikkeling van een deel van de haven naar een 'bedrijventerrein aan de rand van de zee'. De ruimtelijke component is hierbij van groot belang. De Provincie kan inzetten op onder meer de twee kader stellende instrumenten: de Omgevingsvisie en de Omgevingsverordening. Ook zijn de in het Omgevingsbeleid opgenomen operationele doelstellingen van belang, waar de Provincie zichtbaar maakt hoe de Provincie zelf invulling geeft aan de realisatie van het beleid, met een eigen ambitie en inzet (zie 5.1 en 5.2.2). Deze operationele doelstellingen monden dan uit in verschillende uitvoeringsprogramma's en -plannen, zoals het Programma Ruimte en het Programma Mobiliteit. 


\section{Literatuur en websites}

AHN3, 2020. AHN Viewer. Opgeroepen op December 2020, van Actueel Hoogtebestand Nederland:

https://ahn.arcgisonline.nl/ahnviewer/.

Atlas Leefomgeving, 2021. Kaarten. Opgeroepen op Februari 2021, van Atlas Leefomgeving - Verken en ontdek je leefomgeving: https://www.atlasleefomgeving.nl/kaarten.

Bourgeois, R., E. Penunia, S. Bisht \& D. Boruk, 2017. Foresight for all: Co-elaborative scenario building and empowerment. Tehcnological Forecasting and Social Change, 124: 178-188. DOI: https://doi.org/10.1016/j.techfore.2017.04.018.

Burg, S.W.K. van den, H. Gagevos \& R.J.K. Helmes, 2021. Towards sustainable European seaweed value chains: a triple $P$ perspective. ICES Journal of Marine Science, 78(1): 443-450. DOI: https://doi.org/10.1093/icesjms/fsz183.

Carmel, E., 2019. Governance Analysis: Critical Enquiry at the Intersection of Politics, Policy and Society. Edward Elgar Publishing, Cheltenham, VK. URL: https://www.eelgar.com/shop/gbp/governance-analysis-9781788111744.html.

CBS, 2020. Standaard Bedrijfsindeling (SBI). Centraal Bureau voor de Statistiek (CBS), Den Haag, Nederland. URL: https://sbi.cbs.nl/CBS.TypeerModule.TypeerServiceWebAPI/content/angular/app/\#/.

Cornwall, W., 2020. The Paris climate pact is 5 years old. Is it working? Climate European News Science and Policy. DOI: $10.1126 /$ science.abg1263.

CPB \& PBL, 2015a. Cahier Klimaat en energie. Centraal Planbureau (CPB) \& Planbureau voor de Leefomgeving (PBL), Den Haag, Nederland. URL:

https://www.cpb.nl/sites/default/files/publicaties/bijlagen/cpb-pbl-boek-19-wlo-2015-klimaat-enenergie.pdf.

CPB \& PBL, 2015b. Nederland in 2030 en 2050: twee referentiescenario's. Centraal Planbureau (CPB) \& Planbureau voor de Leefomgeving (PBL), Den Haag, Nederland. URL:

https://www.cpb.nl/sites/default/files/publicaties/download/cpb-pbl-boek-19-wlo-2015-nederland2030-en-2050.pdf.

De Bosatlas, 2007. De Bosatlas van Nederland. Wolters-Noordhoff Atlas Productions, Groningen, Nederland.

Deltares, 2019. Mogelijke gevolgen van versnelde zeespiegelstijging voor het Deltaprogramma: een verkenning. Deltares rapport 11202230-005-0002, Delft, Nederland.

Erasmus Universiteit, 2018. Het Rotterdam effect: de impact van Mainport Rotterdam op de Nederlandse economie. Erasmus UPT, Erasmus Universiteit Rotterdam, Nederland. 43pp.

EZK, 2018. Structuurvisie Windenergie op Zee. Ministerie van Economische Zaken (EZK), Den Haag, Nederland. 13pp. Online:

https://www.tweedekamer.nl/kamerstukken/brieven_regering/detail?id=2018Z05409\&did=2018D 21716.

I\&M, 2012. Structuurvisie Infrastructuur en Ruimte. Minister van Infrastructuur en Milieu (I\&M), Den Haag, Nederland. Online:

https://www.rijksoverheid.nl/documenten/rapporten/2012/03/13/structuurvisie-infrastructuur-enruimte.

I\&M, 2013. Nationale Visie Kust: Kompas voor de Kust. Minister van Infrastructuur en Milieu (I\&M), Den Haag, Nederland. Online: https://puc.overheid.nl/rijkswaterstaat/doc/PUC_144704_31/.

I\&W, 2014. Beleidsnota Drinkwater. Ministerie van Infrastructuur en Waterstaat (I\&W), Den Haag, Nederland. Online: https://www.rijksoverheid.nl/documenten/beleidsnotas/2014/04/25/beleidsnota-drinkwater.

I\&W, 2017. Kustpact. Ministerie van Infrastructuur en Waterstaat (I\&W), Den Haag, Nederland. Online: https://www. rijksoverheid.nl/documenten/convenanten/2017/02/21/kustpact.

Jongbloed, R.H., J.E. Tamis en J. Steenbergen, 2020. Expert inschatting van nieuwe windparkzoekgebieden op de Noordzee voor verschillende soortgroepen. Rapport C097/20, Wageningen Marine Research, Den Helder, Nederland. URL: https://doi.org/10.18174/533540.

LISA, 2020. Landelijk Informatiesysteem van Arbeidsplaatsen (LISA). URL: https://www.lisa. nl/. 
Noordzeeloket, 2021a. Kabels en leidingen. Opgeroepen op Maart 2021, van Noordzeeloket:

https://www. noordzeeloket.nl/functies-gebruik/kabels-leidingen/.

Noordzeeloket, 2021b. Natuur en biodiversiteit. Opgeroepen op Maart 2021, van Noordzeeloket: https://www. noordzeeloket.nl/functies-gebruik/natuur/.

Noordzeeloket, 2021c. Olie- en gaswinning. Opgeroepen op Maart 2021, van Noordzeeloket: https://www. noordzeeloket.nl/functies-gebruik/olie-gaswinning/.

Noordzeeloket, 2021d. Recreatie en toerisme. Opgeroepen op Maart 2021, van Noordzeeloket: https://www. noordzeeloket.nl/functies-gebruik/recreatie-toerisme/.

Noordzeeloket, 2021e. Scheepvaart. Opgeroepen op Maart 2021, van Noordzeeloket: https://www.noordzeeloket.nl/functies-gebruik/scheepvaart/.

Noordzeeloket, 2021f. Visserij. Opgeroepen op Maart 2021, van Noordzeeloket: https://www. noordzeeloket. nl/functies-gebruik/visserij/.

Noordzeeloket, 2021g. Windenergie op zee. Opgeroepen op Maart 2021, van Noordzeeloket: https://www. noordzeeloket.nl/functies-gebruik/windenergie/.

Oosterhaven, J., 2019. Rethinking Input-Output Analysis: A Spatial Perspective. Springer Nature, Cham, Switzerland. URL: https://link.springer.com/book/10.1007\%2F978-3-030-33447-5.

Oude Elferink, A.G., 2020. Identificatie en analyse van relevante regelgeving en beleid in het kader van het project 'beleid en regelgeving informatiesysteem noordzee' (BREIN): herziening 2020. Universiteit Utrecht, Utrecht, Nederland. Online: https://www.noordzeeloket.nl/@167054/breinherziening-2020-eindrapport/.

PBL, 2018. De toekomst van de Noordzee - De Noordzee in 2030 en 2050: een scenariostudie. Planbureau voor de Leefomgeving (PBL), Den Haag, Nederland. URL:

https://www.pbl.nl/sites/default/files/cms/publicaties/pbl-2018-toekomst-van-de-noordzee2728. pdf.

PBL, 2019. Achtergronden bij de Toekomst van de Noordzee: onderliggende gegevens en aannames. Planbureau voor de Leefomgeving (PBL), Den Haag, Nederland. URL:

https://www.pbl.nl/sites/default/files/cms/publicaties/pbl-2019-achtergronden-bij-de-toekomstvan-de-noordzee_3177.pdf.

Reijden, K.J., N.T. Hintzen, L.L. Govers, A.D. Rijnsdorp \& H. Olff, 2018. North Sea demersal fisheries prefer specific benthic habitats. PLoS ONE 13(12): e0208338.

Rijksoverheid, 2015. Nationaal Strategisch Plan Aquacultuur 2014-2020. Kamerstuk 32201, nr. 75, Den Haag, Nederland. URL:

https://www.parlementairemonitor.nl/9353000/1/j9vvij5epmj1ey0/vjsgnjes1vsj.

Roebeling, P.C., W.J. Strietman, R. Jongbloed, et al., 2021. De economische en ecologische effecten van inrichtingsvarianten voor de Noordzee tot 2040/2050. Rapport 2021-063, Wageningen Economic Research, Wageningen, Nederland. URL: https://doi.org/10.18174/548296.

RIVM, 2021. Energietransitie. Rijksinstituut voor Volksgezondheid en Milieu (RIVM), Ministerie van Volksgezondheid, Welzijn en Sport (VWS), Bilthoven, Nederland. Online:

https://www.rivm.nl/onderwerpen/energietransitie.

Simensen, T., R. Halvorsen \& L. Erikstad, 2018. Methods for landscape characterisation and mapping: a systematic review. Land Use Policy, 75: 557-569.

Sprenger, C. \& S. ten Have, 1996. Kennismanagement als motor van de lerende organisatie. Reprint uit Holland Management Review no. 51, 1996.

Van der Steen, M., J. Scherpenisse \& M. van Twist, 2015. Sedimentatie in sturing: systeem brengen in netwerkend werken door meervoudig organiseren. Nederlandse School voor Openbaar Bestuur (NSOB), Den Haag, Nederland. URL: https://www.nsob.nl/sites/www.nsob.nl/files/2019-10/NSOB2015-Sedimentatiein-sturing.pdf.

Unsplash, 2021. Opgeroepen op Februari 2021, van Unsplash: https://unsplash.com. 


\section{Bijlage 1 Methode}

In deze studie wordt een mix van methoden toegepast. De basis is de co-elaborative scenario building methodiek (zie bijvoorbeeld Bourgeois et al.,2017; B1.1) die wordt ingezet om samen met stakeholders via co-creatie tot scenario's voor de toekomst te komen (B1.2). Voor het evalueren van de economische effecten wordt de input-output methodiek gebruikt (zie bijvoorbeeld Oosterhaven, 2019; B1.3) en voor het evalueren van de ruimtelijke omgevings effecten wordt de landscape characterisation and mapping methodiek gebruikt (zie bijvoorbeeld Simensen et al., 2018; B1.4). Tot slot, de governance- en beleidsanalyse bouwt op een deskresearch, overleg met de provincie en interactie met de stakeholders (zie bijvoorbeeld Carmel, 2019; B1.5).

\section{B1.1 Co-elaborative scenario building}

In de eerste ronde van workshops (WS-Fase1) hebben we inzicht gekregen in welke trends \& ontwikkelingen relevant zijn en of deze trends \& ontwikkelingen kansen creëren of juist bedreigingen vormen voor belanghebbenden in de Provincie Zuid-Holland. De outputs van deze WS-Fase1 vormden, vervolgens, de input voor de ontwikkeling van de scenario's voor de toekomst voor de Provincie ZuidHolland. Als uitgangspunt hiervoor nemen we de Noordzeescenario's ontwikkeld door PBL (2018, 2019). De Noordzeescenario's ontwikkeld door PBL $(2018,2019)$ zijn gebaseerd op (zie Figuur B1.1):

- Twee scenario's uit de toekomstverkenning Welvaart en Leefomgeving (WLO) voor Nederland in 2030 en 2050 (CPB \& PBL, 2015a, 2015b). Deze scenario's worden, op de horizontale as, gekenmerkt door een van lage naar hoge dynamiek van economische, technologische, klimatologische en andere ontwikkelingen. De scenario's gaan ervan uit dat: i) het vaststaande beleid in 2015 ongewijzigd wordt voortgezet, ii) de toezeggingen van individuele landen om de uitstoot van broeikasgassen te verminderen zijn meegenomen en iii) de ambities van het Klimaatakkoord van Parijs (2015) niet worden gehaald.

- Twee 'duurzame' scenario's waarin extra beleid is verondersteld dat kan bijdragen aan de ambities van het Klimaatakkoord van Parijs en het VN-doel voor duurzame ontwikkeling van de Noordzee. Deze scenario's worden, op de verticale as, gekenmerkt door een transitie van vaststaand beleid naar duurzame ambitie. Deze scenario's bieden de mogelijkheid om te verkennen hoe invulling kan worden gegeven aan de volgende thema's uit de Noordzeestrategie 2030 en de Nationale Omgevingsvisie: i) energietransitie, ii) robuuste natuur en iii) toekomstbestendige voedselvoorziening.

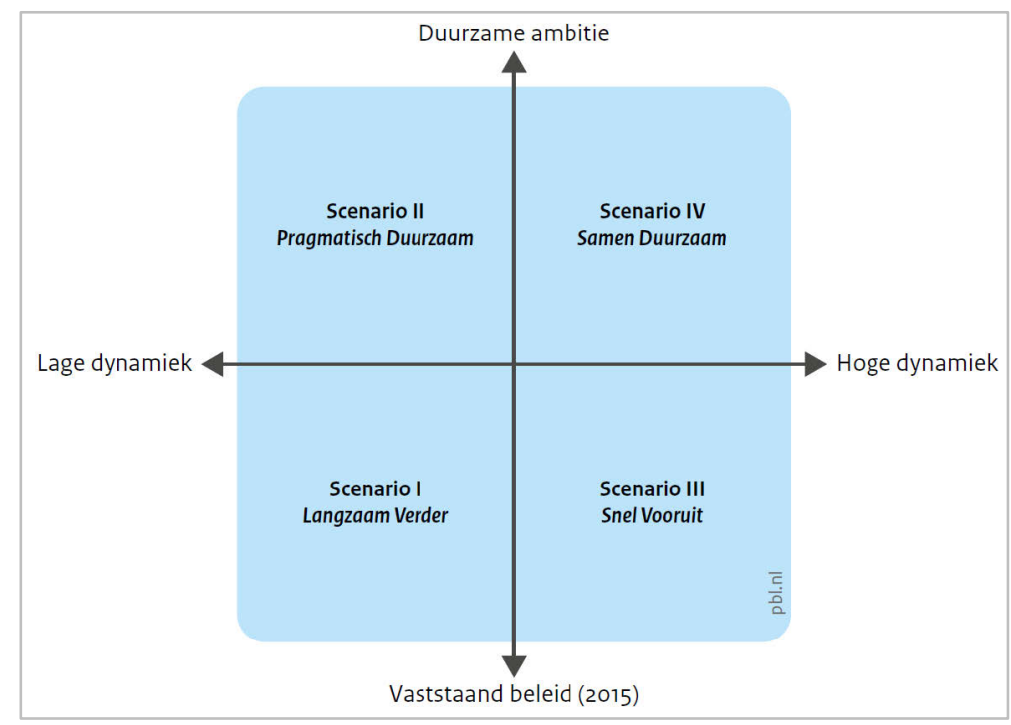

Figuur B1.1 Noordzeescenario's voor 2030 en 2050

Bron: PBL (2018: p.9) 
De combinatie van de WLO-scenario's en de duurzame scenario's leidt, vervolgens, tot de volgende vier scenario's (zie Figuur B1.1):

- Scenario I - Langzaam Verder (PBL, 2018: p.37): Door toenemende internationale conflicten en toenemend nationalisme stagneert de globalisering. Omdat gevestigde belangen steeds meer voorop komen te staan, krijgen innovaties weinig kans en verloopt de technologische ontwikkeling traag. De mondiale klimaatafspraken van Parijs worden maar gedeeltelijk nagekomen. Het Nederlandse en Europese beleid worden meer gericht op het bevorderen van economische groei en banen. De sectoren die op de Noordzee actief zijn, worden nauwelijks duurzamer en op termijn neemt windenergie op zee weinig toe.

- Scenario II - Pragmatisch Duurzaam (PBL, 2018: p.42): Wereldwijd wordt de economische groei geremd door een haperende globalisering en een trage technologische vooruitgang. Die worden op hun beurt in de hand gewerkt door de beperkte concurrentie. In het licht van de klimaatafspraken zijn er wel initiatieven voor groene innovaties, waardoor de mondiale temperatuurstijging beperkt blijft. Het Europese en nationale beleid zijn gericht op een vitale economie, maar niet per se op een hoge groei. De ambities dragen bij aan een verduurzaming van de sectoren die actief zijn op de Noordzee en de realisering van veel windenergie en $\mathrm{CO}_{2}$-opslag op zee.

- Scenario III - Snel Vooruit (PBL, 2018: p.46): Een versnelde globalisering en technologische ontwikkeling stimuleren de economische groei. De mondiale klimaatafspraken uit het Parijsakkoord worden eerst voortvarend opgepakt, maar later blijkt de uitvoering onvoldoende om de klimaatdoelen te bereiken. Zowel het Europese als nationale beleid blijft gericht op duurzaamheid, maar materiële welvaart krijgt een groter accent. De sectoren die actief zijn op zee worden niet veel duurzamer, maar doordat windenergie op zee winstgevend wordt, nemen de windambities wel sterk toe. Op de Doggersbank verschijnt een eiland dat als energie-hub dient.

- Scenario IV - Samen Duurzaam (PBL, 2018: p.50): Een verdergaande globalisering en een snelle technologische ontwikkeling stimuleren de economische groei. Het consequent nakomen van de klimaatafspraken draagt bij aan de beperking van de temperatuurstijging. Het Europese en Nederlandse beleid zijn gericht op het realiseren van een transitie naar een circulaire economie. De sectoren die actief zijn op de Noordzee worden veel duurzamer en er komen veel nieuwe windparken in combinatie met andere vormen van hernieuwbare energie. Er verschijnt eveneens een aantal eilanden die als energie-hubs dienen.

De Noordzeescenario's ontwikkeld door PBL, staan uitgebreid beschreven in PBL (2018) en onderbouwd in PBL (2019). Relevante additionele kenmerken voor de Provincie Zuid-Holland hebben betrekking tot visserij en verwerking, aquacultuur en verwerking, verzilting in landbouw, aanvoer voor en aanlanding van wind op zee (WOZ) en/of carbon-capture \& storage (CCS), statisch en dynamisch kustbeheer en, tot slot, toerisme en recreatie op land, aan kust en op zee.

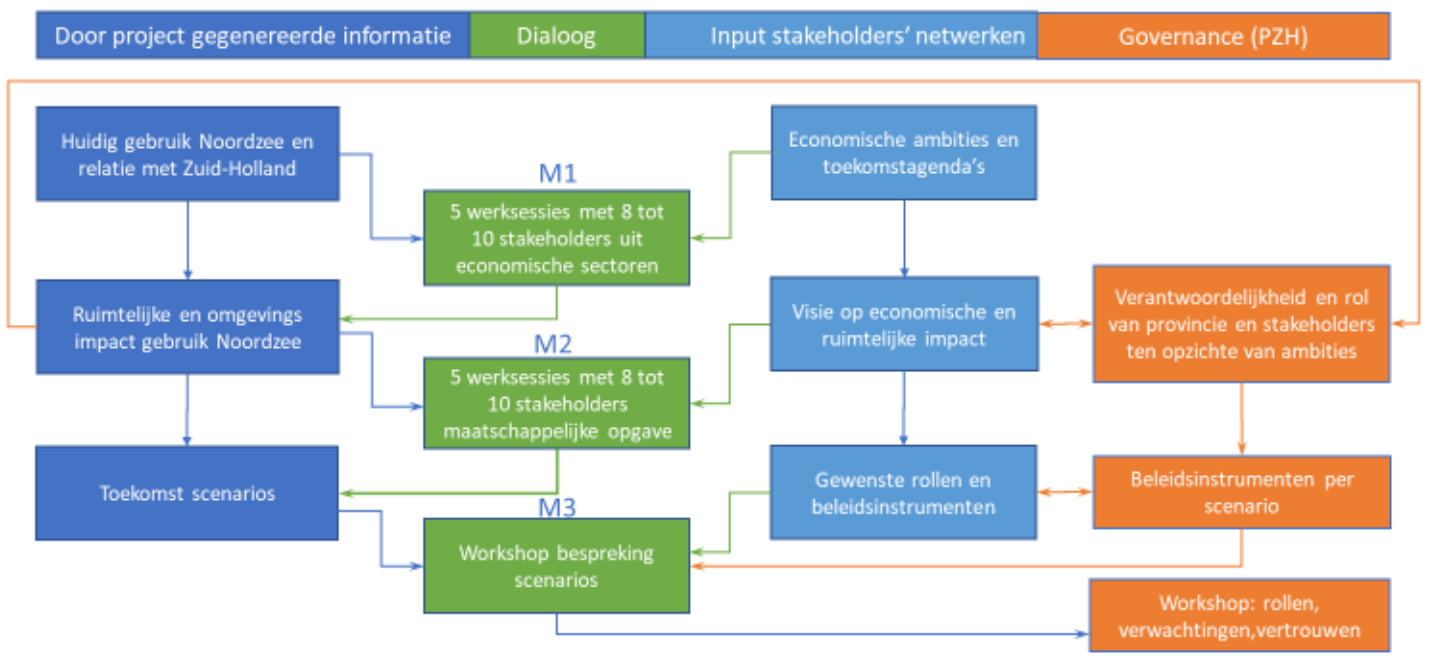




\section{B1.2 Stakeholder co-creatie}

Er hebben drie rondes van stakeholder workshops plaatsgevonden. In alle workshops werd digitaal vergaderd via Microsoft Teams; en gewerkt met de digitale 'flipover' Mural. Het overkoepelende doel van de stakeholders betrokkenheid was het verkrijgen van draagvlak binnen de provincie voor de Noordzee- en kuststrategieën van Provincie Zuid-Holland, zowel inhoudelijk (input van stakeholders, zie bovenstaand figuur), als procesmatig (de workshop voor creëren van kansen in de directe dialoog en van verbinding/vertrouwen tussen stakeholders uit verschillende netwerken op het thema Noordzee en kust).

1. Doel workshops ronde 1 (WS-Fase1): in kaart te brengen van de trends en kansen die deelnemers zien bij de ontwikkelingen op de Noordzee. Hierbij werden stakeholders naar sectorale kennis onderverdeeld

2. Doel workshops ronde 2 (WS-Fase2): deelnemers' perspectief op de ruimtelijke gevolgen van vier scenario's. Hierbij werden de stakeholders uit de verschillende sectoren per gebiedsuitdaging onderverdeeld.

3. Doel workshops ronde 3 (WS-Fase3): integratie en samenwerking van deelnemers uit de verschillende sectoren. Aan de hand van een opdracht werden deelnemers gevraagd als team een advies uit te brengen (rollenspel). De opdrachten waren gebaseerd op twee van de vier scenario's.

Tabel B1.1 Deelname aan workshops

\begin{tabular}{|c|c|c|c|c|}
\hline \multirow[t]{2}{*}{ Ronde } & \multirow[t]{2}{*}{ Datum } & \multirow[t]{2}{*}{ Thema } & \multicolumn{2}{|c|}{ Aantal deelnemers } \\
\hline & & & Excl projectteam & Incl. projectteam \\
\hline \multirow[t]{2}{*}{1} & 4 nov 2020 & Maritiem transport en energie & 7 & 12 \\
\hline & 6 nov 2020 & Voedsel & 4 & 8 \\
\hline \multirow[t]{2}{*}{2} & 3 dec 2020 & Natuur en dynamische kust & 7 & 10 \\
\hline & 21 dec 2020 & Havens en energie & 5 & 9 \\
\hline \multirow[t]{2}{*}{3} & 7 jan 2021 & Groep A: scenario 'Langzaam verder' & 7 & 10 \\
\hline & & Groep B: scenario 'Samen duurzaam' & 6 & 10 \\
\hline
\end{tabular}

Tabel B1.2 Continuïteit van deelname

\begin{tabular}{|c|c|c|c|c|c|c|}
\hline Aantal malen deelgenomen & $1 x$ & $2 \mathrm{x}$ & $3 x$ & $4 x$ & $5 x$ & Totaal \\
\hline Aantal deelnemers & 23 & 3 & 3 & - & 2 & 31 \\
\hline Aantal genodigde mensen gedurende het traject & & & & & & 87 \\
\hline
\end{tabular}


Table B1.3 Deelnemers aan de workshops*

\begin{tabular}{|c|c|c|c|c|c|c|c|c|c|c|c|}
\hline & & & & Ronde 1: $\operatorname{Tr}$ & inds en Kan & & Ronde 2: & Ruimtelijke or & ning & $\begin{array}{l}\text { Ronde } 3: \\
\text { Integrati } \\
\text { samenwe }\end{array}$ & $\begin{array}{l}\text { e en } \\
\text { erking }\end{array}$ \\
\hline & & & & 4-nov-20 & 5-nov-20 & 6-nov-20 & 3-12-202 & & 21-dec-20 & 7-jan-21 & \\
\hline & & & & $\begin{array}{l}\text { Maritiem } \\
\text { transport \& } \\
\text { Energie }\end{array}$ & $\begin{array}{l}\text { Ecologie; } \\
\text { natuur \& } \\
\text { recreatie }\end{array}$ & Voedsel & $\begin{array}{l}\text { Noord- } \\
\text { zee }\end{array}$ & $\begin{array}{l}\text { Natuur \& } \\
\text { Dynamische } \\
\text { kust }\end{array}$ & Havens & Groep A & Groep B \\
\hline 1 & Berkel & Marcel van & Circular Biobased Delta / Network & & & $\mathrm{x}$ & & & $x$ & & $\mathrm{x}$ \\
\hline 2 & Boode & Stijn & Hiswa - Recron & & $\mathrm{x}$ & & & & & & \\
\hline 3 & Damsma & Petra & Rijkswaterstaat & & & & & $x$ & & & \\
\hline 4 & Duijn & Manon van & $\mathrm{PZH}$ & $\mathrm{x}$ & & & & & & & \\
\hline 5 & Eichler & Joël & Beleidsadviseur Econom. Zaken & & & & & & & & $\mathrm{x}$ \\
\hline 6 & Gilding & Edward & Maritime Delta Programma & $\mathrm{x}$ & & & & & & & \\
\hline 7 & Hartgerink & Odette & $\mathrm{PZH}$ & & $\mathrm{x}$ & & & & & & \\
\hline 8 & Horst & Martijn van der & $\begin{array}{l}\text { Kennisinstituut voor Mobiliteitsbeleid, Min } \\
\text { I\&W }\end{array}$ & $x$ & & & & & & & \\
\hline 9 & Janssen & Marc & Stichting Duinbehoud & & & & & $x$ & & $x$ & \\
\hline 10 & Jonker & Ton & Innovation officer PZH & $\mathrm{x}$ & $\mathrm{x}$ & $x$ & & & $x$ & $x$ & \\
\hline 11 & Kastelein & Jaco & LTO -Noord & & & & & & & $x$ & \\
\hline 12 & Kelder & Tina & Min I\&W & & & $\mathrm{x}$ & & & & & \\
\hline 13 & Kersen & Hidde van & MSC & & & & $x$ & & & & \\
\hline 14 & Lazar & Marian & RWS - Zee \& Delta & & & & $x$ & & & & \\
\hline 15 & Leltz & Georgette & Nationaal Park Hollandse Duinen & & & & & & & & $x$ \\
\hline 16 & Lindeloof & Arjan van de & PZH Thematrekker E\&K & & $x$ & $x$ & $x$ & & $x$ & & $x$ \\
\hline 17 & Luijben & Tessa van & Innovation Quarter & $x$ & & & & & & & \\
\hline 18 & Mahler & Matthijs & PZH Thematrekker MT & & & & & & & & $x$ \\
\hline 19 & Minkelis & Niels van de & $\begin{array}{l}\text { Koninklijke Vereniging van Nederlandse } \\
\text { Reders (KVNR) }\end{array}$ & $x$ & & & & & & & \\
\hline 20 & Mulder & Irene & Gemeente Den Haag & & & & & & & $x$ & \\
\hline 21 & Nes-de Man & Petra van & Waterschap Hollandse Delta & & & & & $x$ & & & \\
\hline 22 & Netten & Felix & PZH/Vlaams Nederlandse Delta (VND) & & & & & & & & $x$ \\
\hline 23 & Oelen & Jan Peter & RVO & & & & $x$ & & & & \\
\hline 24 & Oosten-Däpp & Jessica van & Hoogheemraadschap Delfland & & $x$ & & $x$ & $x$ & & & \\
\hline 25 & Perdijk & Edwin & Energie, PZH & & & & & & $\mathrm{x}$ & $\mathrm{x}$ & \\
\hline
\end{tabular}




\begin{tabular}{|c|c|c|c|c|c|c|c|c|c|c|c|}
\hline & & & & \multicolumn{3}{|c|}{ Ronde 1: Trends en Kansen } & \multicolumn{3}{|c|}{ Ronde 2: Ruimtelijke ordening } & \multicolumn{2}{|c|}{$\begin{array}{l}\text { Ronde 3: } \\
\text { Integratie en } \\
\text { samenwerking }\end{array}$} \\
\hline & & & & 4-nov-20 & 5-nov-20 & 6-nov-20 & $3-12-202$ & & 21-dec-20 & 7-jan-21 & \\
\hline & & & & $\begin{array}{l}\text { Maritiem } \\
\text { transport \& } \\
\text { Energie }\end{array}$ & $\begin{array}{l}\text { Ecologie; } \\
\text { natuur \& } \\
\text { recreatie }\end{array}$ & Voedsel & $\begin{array}{l}\text { Noord- } \\
\text { zee }\end{array}$ & $\begin{array}{l}\text { Natuur } \& \\
\text { Dynamische } \\
\text { kust }\end{array}$ & Havens & Groep A & Groep B \\
\hline 26 & Rood & Karin & DUNEA & & & & & $x$ & & & \\
\hline 27 & Schaick & Jeroen van & Nexus / PZH & & & & & & $x$ & & $x$ \\
\hline 28 & Snoo & Nick de & Hoofd Staatsbosbeheer ZH & & & & & & & & \\
\hline 29 & Steekelenburg & Marco van & Stedenbouwkundige, PZH & $x$ & & & & $x$ & & $x$ & \\
\hline 30 & Swam & Koen van & Stichting Noordzeeboerderij & & & & $x$ & & & & \\
\hline 31 & Vertegaal & Kees & Kustecoloog & & & & & $x$ & & & \\
\hline 32 & Wagt & Lenny van der & Gemeente Noordwijk & & & & & & & $x$ & \\
\hline \multirow[t]{14}{*}{33} & Zandbrink & Wouter van & $\begin{array}{l}\text { Visfederatie - Vereniging van } \\
\text { Schelpdierhandelaren }\end{array}$ & & & & $x$ & & & & \\
\hline & & Aantal aanwez & excl. Projectteam & 7 & 5 & 4 & 7 & 7 & 5 & 7 & 7 \\
\hline & & Aantal aanwez & incl. Projectteam & 12 & 9 & 8 & 10 & 9 & 9 & 10 & 11 \\
\hline & Projectteam & & & & & & & & & & \\
\hline & Burg & Sander van den & Wageningen Economic Research & & & $x$ & & $x$ & & & $x$ \\
\hline & Kempen & Hans van & LOS Stad Om Land & & $x$ & & & $x$ & & & \\
\hline & Langevelde & Abco van & Ecorys & & $x$ & & & & $x$ & & \\
\hline & Rij & Anna van & LOS Stad Om Land & $x$ & & $x$ & $x$ & & $x$ & $x$ & \\
\hline & Rijswijk & Sophie van & LOS Stad Om Land & & & & & & & & $x$ \\
\hline & Roebeling & Peter & Wageningen Economic Research & $x$ & $x$ & $x$ & & & $x$ & $x$ & \\
\hline & Schutte & Hannah & Ecorys & $x$ & & & & & & & \\
\hline & Selnes & Trond & Wageningen Economic Research & & & & $x$ & & & $x$ & \\
\hline & Valk & Olga van der & Wageningen Economic Research & $x$ & $x$ & $x$ & $x$ & & $x$ & & $x$ \\
\hline & Verkennis & Atze & Ecorys & $x$ & & & & & & & $x$ \\
\hline
\end{tabular}

* Cumulatief gedurende het verloop van het project: niet alle personen zijn voor alle workshops uitgenodigd. 


\section{B1.3 Economic impacts}

\section{Bepalen huidige economisch belang en ontwikkeling per sector}

Voor het evalueren van de economische effecten wordt de input-output methodiek gebruikt (zie Oosterhaven, 2019). Het huidige economische belang van de Noordzee voor de Provincie Zuid-Holland is bepaald aan de hand van een inventarisatie van sectoren met een directe of indirecte relatie tot de Noordzee. Voor het bepalen van de huidige economische situatie is een inventarisatie van (karakteristieken van) activiteiten die met de Noordzee samenhangen geïdentificeerd en gespecificeerd. Daarbij is per sector een lijst met relevante (op een of andere wijze aan de Noordzee gerelateerde) activiteiten opgesteld op basis van de SBI-classificatie van CBS op 5-digitniveau. Voor de betreffende activiteiten is een analyse van karakteristieken/kenmerken gemaakt op basis van SBIinformatie (CBS, 2020), CBS-data ${ }^{11}$ en data uit het Landelijk Informatiesysteem van Arbeidsplaatsen (LISA, 2020), met betrekking tot economische indicatoren (zoals aantal vestigingen, werkgelegenheid en ruimtebeslag). De analyses zijn gemaakt voor Zuid-Holland als geheel, maar ook uitgesplitst voor de regio's Haaglanden, Rotterdam, Drechtsteden en overig Zuid-Holland. Daarbij is uitgegaan van de cijfers over 2019. Door een zelfde uitdraai te maken van cijfers uit 2014/2016 is een analyse gemaakt van de ontwikkeling van het belang van sectoren als geheel en de ontwikkeling van de activiteiten binnen de sectoren. Informatie over de periode voor 2014/2016 bleek niet in dezelfde vorm verkrijgbaar.

Bepalen economische impact van verwachte ontwikkelingen

Voor het bepalen van toekomstige ontwikkelingen en de economische impacts daarvan is gebruik gemaakt van de eerder toegelichte scenario's. De impact van deze ontwikkelingen is geïdentificeerd op basis van eerdere ervaring met eerdere impactanalyses, aangevuld met deskstudie en informatie uit de gehouden werksessies. Daarbij zijn per scenario verschillende ontwikkelingen uitgelicht. Waar mogelijk zijn de daarmee samenhangende effecten in kaart gebracht en gewaardeerd. Per ontwikkeling is aangegeven welke invloed dit heeft op de ontwikkeling van het aantal banen in de sector of op de ontwikkeling van het ruimtebeslag van de sector. Hierbij is ingegaan op de richting en sterkte van de ontwikkeling van het aantal banen en het ruimtebeslag. De ontwikkeling gaat in op het nettoresultaat. Wanneer een ontwikkeling tot een nettotoename van het aantal banen of van het ruimtebeslag leidt, is dit aangegeven met een (donker) groene kleur. Een nettodaling is aangegeven met een (donker) oranje kleur. Wanneer het totale aantal banen ongeveer gelijk blijft (doordat geen ontwikkeling plaatsvindt of er slechts een verschuiving in het aantal plaatsvindt) is dit aangegeven met een licht gele kleur.

\section{B1.4 Landscape characterisation and mapping}

De onderwerpen van deze studie draaien om connectiviteit: welke fenomenen op de Noordzee zijn verbonden met het land. Dit kan gaan om waterrecreatie aan het strand, goederenstromen, visserij, visteelt, zand dat van zee naar land beweegt en vice versa, uitzichten op zee vanuit onze 'Noordzeeboulevards' of ondergrondse (zoute) water(kwel)stromen. Deze onderwerpen zijn uitgewerkt met de landscape characterisation and mapping methodiek (zie bijvoorbeeld Simensen et al., 2018).

Documenten van de Rijksoverheid (zoals de Rijksstructuurvisie Windenergie op Zee, de Beleidsnota Noordzee 2016-2021, het Programma Noordzee 2022-2027, de Verkenning Noordzeestrategie 2030 en het Noordzeeakkoord) en documenten van de Provincie (zoals de Agenda Kust Zuid-Holland en de Innovatievisie Land \& Zee 2030), evenals gebiedsprofielen en kwaliteitskaarten, Atlas Leefomgeving, (2021) en een breed scala aan bronnen die specifieke informatie verbeelden.

${ }^{11}$ https://opendata.cbs.nl/statline/\#/CBS/nl/ 


\section{B1.5 Governance and policy analysis}

De Provincie Zuid-Holland werkt aan sector-verbindende integratie van beleid en ziet zichzelf als verbinder die bestaande en nieuwe netwerken wil mobiliseren. De taak van de Provincie ligt hierbij vooral op de bovenregionale belangen. Die belangen zijn de basis voor provinciale meervoudige sturing met als oogmerk het leveren van toegevoegde waarde. Sturing kan variëren van het bieden van ruimte, samenwerken en het maken van afspraken, tot het afdwingen. Daarbij baseert de provincie zich op het NSOB kwadrant. ${ }^{12}$ De provincie stelt zich meer sturend op naarmate de bijdragen aan een maatschappelijke opgave en het maatschappelijk belang groter is. De beleidsinstrumenten die de provincie hierbij tot haar beschikking heeft staan vallen uiteen in juridische, economische of communicatieve prikkels. De governance-/beleidsanalyse (Carmel, 2019) bouwt op deskresearch, gesprekken met provinciale ambtenaren, overleg met de provincie en interactie met de stakeholders.

\footnotetext{
${ }^{12}$ zie https://www.nsob.nl/sites/www.nsob.nl/files/2019-10/NSOB-2015-Sedimentatiein-sturing.pdf
} 


\section{Bijlage 2 Trends \& ontwikkelingen}

Centraal in dit toekomstonderzoek staan de trends \& ontwikkelingen op en rond de Noordzee, en welke kansen en/of bedreigingen deze trends \& ontwikkeling bieden voor het realiseren van de ambities van de provincie en belanghebbenden. Dit binnen de kaders van exogene globale trends (zoals klimaatverandering) en overkoepelende ambities (zoals bepaald op nationaal of Europees niveau). Trends en ontwikkelingen beschrijven we voor de thema's Ecologie \& klimaat (B2.1), Recreatie (B2.2), Maritiem transport (B2.3), Energie (B2.4) en Voedsel (B2.5).

\section{B2.1 Ecologie \& klimaat}

Met betrekking tot Ecologie \& klimaat worden, onder andere, de volgende trends \& ontwikkelingen relevant geacht (zie Tabel B2.1).

Tabel B2.1 Trends \& ontwikkelingen in Ecologie \& klimaat

\begin{tabular}{|c|c|c|}
\hline Trend/ontwikkeling & Korte omschrijving & Bronnen \\
\hline Zeespiegelstijging & $\begin{array}{l}\text { De zeespiegel langs de Nederlandse kust is in } \\
129 \text { jaar gelijkmatig gestegen met circa } 24 \mathrm{~cm} \text {, } \\
\text { ofwel een toename met } 1,9 \mathrm{~mm} \text { per jaar. 1,5 mm } \\
\text { daarvan wordt toegeschreven aan } \\
\text { zeespiegelstijging, de rest aan tektonische } \\
\text { bewegingen. }\end{array}$ & $\begin{array}{l}\text { - https://www.clo.nl/indicatoren/nl0229- } \\
\text { zeespiegelstand-nederland-en- } \\
\text { mondiaal?ond=20883 }\end{array}$ \\
\hline $\begin{array}{l}\text { Temperatuurstijging van } \\
\text { het water }\end{array}$ & $\begin{array}{l}\text { Gemiddeld steeg de watertemperatuur van de } \\
\text { oceanen de afgelopen } 45 \text { jaar met } 0,74^{\circ} \mathrm{C} \text {, maar } \\
\text { in de Noordzee was dat } 1,67^{\circ} \mathrm{C} \text {. }\end{array}$ & $\begin{array}{l}\text { - https://www.animalstoday.nl/noordzee- } \\
\text { warmt-sneller-op-dan-gemiddeld/ } \\
\text { (Geen gevalideerde bron) }\end{array}$ \\
\hline Meer natuurkennis & $\begin{array}{l}\text { Een spin-off van de aanleg van windmolens is dat } \\
\text { er veel onderzoek is opgestart naar natuur op de } \\
\text { Noordzee (WOZEP). }\end{array}$ & $\begin{array}{l}\text { - https://www.noordzeeloket.nl/functies- } \\
\text { gebruik/windenergie-zee/ecologie/wind-zee- } \\
\text { ecologisch-programma-wozep/ }\end{array}$ \\
\hline $\begin{array}{l}\text { Toename van zeewier- } \\
\text { en schelpteelt }\end{array}$ & $\begin{array}{l}\text { Een toename van zeewier- en schelpteelt in biedt } \\
\text { mogelijkheden voor, bijvoorbeeld, mogelijkheden } \\
\text { voor nutrientenopname. }\end{array}$ & $\begin{array}{l}\text { - } \text { - https://edepot.wur.nl/478658 } \\
\text { - https://www.agroberichtenbuitenland.nl/spe } \\
\text { cials/voedselzekerheid/zeewier } \\
\text { - https://www.noordzeeboerderij.nl/ }\end{array}$ \\
\hline
\end{tabular}




\section{B2.2 Recreatie}

Met betrekking tot Recreatie worden, onder andere, de volgende trends \& ontwikkelingen relevant geacht (zie Tabel B2.2).

Tabel B2.2 Trends \& ontwikkelingen in Recreatie

\begin{tabular}{|c|c|c|}
\hline Trend/ontwikkeling & Korte omschrijving & Bronnen \\
\hline Economische groei NL & $\begin{array}{l}\text { De Nederlandse economie groeit (straks weer) } \\
\text { en, daarmee, de vraag naar recreatieactiviteiten. }\end{array}$ & $\begin{array}{l}\text { - https://www.cpb.nl/sites/default/files/omni } \\
\text { download/CPB-Visuele-samenvatting- } \\
\text { actualisatie-MLT-2022-2025.pdf }\end{array}$ \\
\hline Bevolkingsgroei NL & $\begin{array}{l}\text { Volgens deze prognose groeit de Nederlandse } \\
\text { bevolking door tot } 19,6 \text { miljoen inwoners in } \\
2060 \text {. }\end{array}$ & $\begin{array}{l}\text { - } \text { https://www.cbs.nl/nl- } \\
\text { nl/achtergrond/2019/51/kernprognose- } \\
\text { 2019-2060-19-miljoen-inwoners-in-2039 }\end{array}$ \\
\hline $\begin{array}{l}\text { Groei internationaal } \\
\text { toerisme }\end{array}$ & $\begin{array}{l}\text { Het internationale toerisme groeit (straks weer) } \\
\text { en beweegt van 'package' naar individueel } \\
\text { toerisme. }\end{array}$ & - https://www.perspectief2030.nl/ \\
\hline Klimaatverandering & $\begin{array}{l}\text { De verwachting is dat de lucht- (tot }+3,7^{\circ} \mathrm{C} \text { in } \\
2085 \text { ) en watertemperatuur }\left(+1,67^{\circ} \mathrm{C} \text { over de }\right. \\
\text { afgelopen } 45 \text { haar) zullen stijgen, hetgeen } \\
\text { potentiele recreatie mogelijkheden biedt. }\end{array}$ & $\begin{array}{l}\text { - https://www.nemokennislink.nl/publicaties/ } \\
\text { het-klimaat-van-de-toekomst-in-nederland/ } \\
\text { - https://www.animalstoday.nl/noordzee- } \\
\text { warmt-sneller-op-dan-gemiddeld/ } \\
\text { (Geen gevalideerde bron) }\end{array}$ \\
\hline Dynamisch kustbeheer & $\begin{array}{l}\text { Dynamisch kustbeheer, zoals de Zandmotor, } \\
\text { loopt nu } 20 \text { jaar en biedt potentiele } \\
\text { recreatiemogelijkheden. }\end{array}$ & $\begin{array}{l}\text { - Een document met een inventarisatie van } \\
\text { projecten dynamisch kustbeheer: } \\
\text { https://www.dynamischkustbeheer.nl/docu } \\
\text { ments/dynamischkustbeheer/documents/vo } \\
\text { orbeelden_van_dynamisch_kustbeheer.pdf }\end{array}$ \\
\hline Nederzettingen op zee & $\begin{array}{l}\text { Op de Noordzee ontstaan (technische) } \\
\text { nederzettingen en komen er booreilanden vrij. } \\
\text { Dit biedt potentiele recreatiemogelijkheden. }\end{array}$ & $\begin{array}{l}\text { - https://www.visitsouthend.co.uk/whats- } \\
\text { on/4035/Maunsell-Forts-Red-Sand-Towers- } \\
\text { Tour/ } \\
\text { - https://spaceatsea-project.eu/ }\end{array}$ \\
\hline
\end{tabular}




\section{B2.3 Maritiem transport}

Met betrekking tot Maritiem transport worden, onder andere, de volgende trends \& ontwikkelingen relevant geacht (zie Tabel B2.3).

Tabel B2.3 Trends \& ontwikkelingen in Maritiem transport

\begin{tabular}{|c|c|c|}
\hline Trend/ontwikkeling & Korte omschrijving & Bronnen \\
\hline Scheepvaart & $\begin{array}{l}\text { Verwachte toename in de hoeveelheid } \\
\text { schepen op de Noordzee }\end{array}$ & $\begin{array}{l}\text { - http://publications.deltares.nl/1204375_00 } \\
\text { 1.pdf }\end{array}$ \\
\hline Brexit & $\begin{array}{l}\text { Effect Brexit op transportbewegingen en } \\
\text { handelsstromen }\end{array}$ & $\begin{array}{l}\text { - https://www. maritiemnederland.com/artike } \\
\text { len/maritiem-achtergrond/vk-moet-geen- } \\
\text { singapore-op-de-noordzee-worden }\end{array}$ \\
\hline Energietransitie & $\begin{array}{l}\text { Afbouw olie- en gaswinning op zee (en } \\
\text { bijbehorende voorzieningen, zoals onderhoud, } \\
\text { transport en raffinaderijen) }\end{array}$ & $\begin{array}{l}\text { - https://www.rijksoverheid.nl/onderwerpen/ } \\
\text { duurzame-energie/toekomst-fossiele- } \\
\text { brandstoffen }\end{array}$ \\
\hline $\begin{array}{l}\text { Groei in ontwikkeling en } \\
\text { onderhoud offshore inst } \\
\text { allaties }\end{array}$ & $\begin{array}{l}\text { Meer transport door onderhoud aan installaties } \\
\text { op zee }\end{array}$ & $\begin{array}{l}\text { - https://www.maritiemland.nl/maritieme- } \\
\text { sector/publicaties/maritieme-monitor-2019/ }\end{array}$ \\
\hline
\end{tabular}




\section{B2.4 Energie}

Met betrekking tot Energie worden, onder andere, de volgende trends \& ontwikkelingen relevant geacht (zie Tabel B2.4).

Tabel B2.4 Trends \& ontwikkelingen in Energie

\begin{tabular}{|c|c|c|}
\hline Trend/ontwikkeling & Korte omschrijving & Bronnen \\
\hline Windenergie op zee & $\begin{array}{l}\text { In het Energieakkoord is afgesproken dat in } \\
20235 \text { windparken moeten zijn gerealiseerd die, } \\
\text { samen met de bestaande windparken, een totaal } \\
\text { vermogen hebben van circa } 4,5 \mathrm{GW} \text {. Op grond } \\
\text { van het regeerakkoord moet daar tussen } 2024 \\
\text { en } 2030 \text { voor nog eens } 7 \mathrm{GW} \text { aan windparken op } \\
\text { zee bij komen. }\end{array}$ & $\begin{array}{l}\text { - https://www.rijksoverheid.nl/actueel/nieuw } \\
\text { s/2018/03/27/kabinet-maakt-plannen- } \\
\text { bekend-voor-windparken-op-zee-2024- } \\
2030 \\
\text { - https://www.rijksoverheid.nl/documenten/k } \\
\text { amerstukken/2018/03/27/kamerbrief- } \\
\text { routekaart-windenergie-op-zee-2030 }\end{array}$ \\
\hline Energietransitie & Streven naar een duurzame energievoorziening & $\begin{array}{l}\text { - https://www.rijksoverheid.nl/onderwerpen/ } \\
\text { duurzame-energie/toekomst-fossiele- } \\
\text { brandstoffen }\end{array}$ \\
\hline $\begin{array}{l}\text { Afname productie en } \\
\text { gebruik fossiele } \\
\text { brandstoffen }\end{array}$ & $\begin{array}{l}\text { Afname productie en gebruik van fossiele } \\
\text { brandstoffen (en bijbehorende voorzieningen, } \\
\text { zoals raffinaderijen, scheepvaart en } \\
\text { buisleidingen) }\end{array}$ & $\begin{array}{l}\text { - https://www.rijksoverheid.nl/onderwerpen/ } \\
\text { duurzame-energie/toekomst-fossiele- } \\
\text { brandstoffen }\end{array}$ \\
\hline CO2 opslag & $\begin{array}{l}\text { Mogelijkheden voor } \mathrm{CO}_{2} \text {-opslag in gasvelden op } \\
\text { de Noordzee }\end{array}$ & $\begin{array}{l}\text { - https://www.noordzeeloket.nl/functies- } \\
\text { gebruik/co2-opslag/ }\end{array}$ \\
\hline $\begin{array}{l}\text { Waterstoffabrieken en } \\
\text { getijdenenergie }\end{array}$ & $\begin{array}{l}\text { Opkomst en ontwikkeling van } \\
\text { waterstoffabrieken en getijdenenergie }\end{array}$ & $\begin{array}{l}\text { - https://www.deltares.nl/nl/issues/duurzam } \\
\text { e-energie-uit-water-en- } \\
\text { ondergrond/getijdenenergie/ } \\
\text { - https://www.tno.nl/nl/aandachtsgebieden/e } \\
\text { nergietransitie/roadmaps/naar-co2- } \\
\text { neutrale-brand-en-grondstoffen/waterstof- } \\
\text { voor-een-duurzame- } \\
\text { energievoorziening/wereldprimeur- } \\
\text { pilotfabriek-groene-waterstof-op-zee/ }\end{array}$ \\
\hline
\end{tabular}




\section{B2.5 Voedsel}

Met betrekking tot Voedsel worden, onder andere, de volgende trends \& ontwikkelingen relevant geacht (zie Tabel B2.5).

Tabel B2.5 Trends \& ontwikkelingen in Voedsel

\begin{tabular}{|c|c|c|}
\hline Trend/ontwikkeling & Korte omschrijving & Bronnen \\
\hline $\begin{array}{l}\text { Toename verzilting door } \\
\text { zeespiegelstijging }\end{array}$ & $\begin{array}{l}\text { Effect van verzilting op opbrengst landbouw en } \\
\text { mogelijke verandering in teelttechnieken en/of } \\
\text { gewaskeuze }\end{array}$ & $\begin{array}{l}\text { - https://edepot.wur.nl/186856 } \\
\text { - Zoetwater in Zuid-Holland - LTO Noord } \\
\text { - Zouttolerantie van teelten }\end{array}$ \\
\hline $\begin{array}{l}\text { Toename verzuring en } \\
\text { temperatuur zeewater } \\
\text { door klimaatverandering }\end{array}$ & $\begin{array}{l}\text { Effect verzuring en temperatuur op visserij en } \\
\text { aqua-/maricultuur }\end{array}$ & $\begin{array}{l}\text { - Klimaatverandering en verzuring van de } \\
\text { zee }\end{array}$ \\
\hline $\begin{array}{l}\text { Selectieve } \\
\text { vangsttechnieken }\end{array}$ & $\begin{array}{l}\text { Bijvoorbeeld het afschaffen van 'flyshoot', } \\
\text { duurzame visserijtechnieken en verminderen } \\
\text { 'by-catch' }\end{array}$ & $\begin{array}{l}\text { - Duurzame vangsttechnieken } \\
\text { - https://visbureau.nl/de-vissector }\end{array}$ \\
\hline $\begin{array}{l}\text { Afname visserij } \\
\text { gebieden }\end{array}$ & $\begin{array}{l}25 \% \text { afname in visserijgebieden als gevolg van } \\
\text { Brexit, windenergie-op-zee (WOZ) en } \\
\text { bescherming natuur }\end{array}$ & $\begin{array}{l}\text { - No deal Brexit: Gevolgen en Maatregelen - } \\
\text { Rijksoverheid } \\
\text { - Kamerbrief routekaart windenergie op zee } \\
2030 \\
\text { - https://www. noordzeeloket.nl/nieuws/nieu } \\
\text { ws/2020/noordzeeakkoord/ }\end{array}$ \\
\hline $\begin{array}{l}\text { Toename van } \\
\text { zeewierteelt }\end{array}$ & $\begin{array}{l}\text { Een toename van zeewierteelt in WOZ gebieden } \\
\text { tot } \sim 400 \mathrm{~km}^{2}\end{array}$ & $\begin{array}{l}\text { - https://edepot.wur.nl/478658 } \\
\text { - https://www.agroberichtenbuitenland.nl/sp } \\
\text { ecials/voedselzekerheid/zeewier } \\
\text { - https://www.noordzeeboerderij.nl/ }\end{array}$ \\
\hline $\begin{array}{l}\text { Veranderende } \\
\text { consumptiepatronen }\end{array}$ & $\begin{array}{l}\text { Shift van dierlijke naar meer plantaardige } \\
\text { eiwitten; grotere aandacht voor gezondere } \\
\text { voeding }\end{array}$ & - $\ldots$ \\
\hline
\end{tabular}




\section{Bijlage 3 Visies, ambities en kansen}

Deze bijlage brengt de stakeholders' visies, ambities en kansen in beeld die zij zien in relatie tot de toekomstige trends en ontwikkelingen op de Noordzee (zie Bijlage 2). Op basis van de input van de deelnemers ten aanzien van van de relevante trends \& ontwikkelingen en gerelateerde kansen (WSFase1), kan het volgende worden afgeleid ten aanzien van Ecologie \& klimaat (B3.1), Recreatie (B3.2), Maritiem transport (B3.3), Energie (B3.4) en Voedsel (B3.5).

\section{B3.1 Ecologie \& klimaat}

Op het gebied van Ecologie \& klimaat verwacht men een toenemende zeespiegelstijging, wat leidt tot de noodzaak de kust ter versterken en aandacht te hebben voor buitendijkse elementen (bijvoorbeeld Kurhaus). Kansen worden gezien in het versterken op huidige locatie, op strand en/of voor kust, hetgeen mogelijkheden biedt voor natuur, medegebruik (bouw; recreatie) en kustinnovatie (kennis exploitatie).

Op het gebied van dynamische kustbeheer krijgt men steeds meer ervaring en het krijgt ook steeds meer aandacht in de samenleving. Dit biedt kansen (bescherming; natuur; bouw; recreatie; toerisme) maar moet wel deel uitmaken van integraal kustbeheer (hard en zacht; waterveiligheid). Zoals hierboven gezegd, dit biedt mogelijkheden voor kustinnovatie en kennis exploitatie.

Een belangrijke langlopende trend is de achteruitgang van de biodiversiteit (zowel wereldwijd, maar ook op de schaal van Nederland).

Er wordt een sterke groei van windenergie-op-zee verwacht. Dit biedt mogelijkheden voor opwekken duurzame energie, groene banen en medegebruik (aquacultuur; recreatie; sportvisserij). Voor natuur zijn er kansen (bijvoorbeeld rifbouwers en benthic) en bedreigingen (bijvoorbeeld zeevogels en zoogdieren).

Men verwacht een zeewater temperatuurstijging en verdere verzuring van de Noordzee. De vraag rijst of dit kansen biedt voor nieuwe soorten en nieuwe vormen van viskweek en voedselwinning.

\section{B3.2 Recreatie}

Op het gebied van Recreatie verwacht men bevolkingsgroei niet alleen in aantallen maar ook in compositie (leeftijd [bijvoorbeeld vergrijzing]; diversiteit) en, dus, toenemende behoefte aan passende woningen, infrastructuur en recreatie mogelijkheden. Dit biedt kansen voor ontwikkeling en spreiding recreatieve en toeristische activiteiten evenals ontwikkeling van passende infrastructuur en transport mogelijkheden.

Een verwachtte groeiende wereldeconomie leidt tot hogere bestedingsniveau bevolking evenals toename in de toestroom van internationale toeristen. Dit biedt kansen voor de vrijetijdsector, gastvrijheidsindustrie en toerisme, waarbij kwaliteit van de geleverde diensten een steeds belangrijkere rol gaat spelen.

Men verwacht een toename in aantal en compositie van internationale toerisme en gerelateerde knelpunten. Kansen bestaan in het neerzetten van de $\mathrm{PZH}$ als international tourist destination met attracties aan kust (natuur; strand; watersport) en in binnenland (natuur; cultuur; erfgoed). Dit vereist ontwikkeling kwaliteit (kustplaatsen; natuur), veiligheid (strandtoerisme; watersport), infrastructuur (toegangswegen), transportmogelijkheden (openbaar vervoer) en marketing. Het is, gezien de COVID-19 ervaring, onduidelijk welke ontwikkeling zakelijk toerisme zal doormaken. 
Onafhankelijk van de trend, zijn er kansen om zakelijke en toeristische diensten te integreren (nieuw businessmodel).

De opwarming van het klimaat en de daaraan gerelateerde trek naar water worden als belangrijke trends gezien. Deze bieden kansen in verlenging van het zomerseizoen, spreiden van strandtoerisme over kust, scheiden van activiteiten (badgasten; watersporters) en aanbieden van activiteiten aan kust en op land. Dit vereist, wederom, aandacht voor kwaliteit, veiligheid, infrastructuur, transportmogelijkheden en marketing.

Beleving en variatie in toerisme en recreatie spelen in toenemende een rol. Dit biedt kansen voor integreren van kust en achterland, cultuur en natuur en ontspanning en actie. Kwaliteit, ontsluiting en bereikbaarheid zijn, daarbij, belangrijke randvoorwaarden. Deze diensten kunnen, bijvoorbeeld in de vorm van arrangementen, het hele jaar worden geleverd.

Nieuwe vormen van toerisme en recreatie zijn te vinden in eilanden/windparken op zee en nieuwe vormen van watersport. De eerste bieden kansen voor culturele, sportvisserij en watersport activiteiten, terwijl de laatste kansen bieden voor een bredere inzetbaarheid, levensstijl en actie.

\section{B3.3 Maritiem transport}

Op het gebied van Maritiem transport verwacht men in de scheepvaart men een groei en, in combinatie met trends in visserij en windenergie-op-zee, is aandacht voor nieuwe scheepvaartroutes (via de Noordpool) en scheepvaartveiligheid van belang. Technologische ontwikkelingen omvatten het gebruik van grotere schepen, alternatieve brandstoffen, efficiëntere logistiek en autonoom varen. Visserij scheepvaart en windenergie-op-zee concurreren om dezelfde gebieden. Kansen worden gezien in alternatieve brandstoffen, autonome scheepsvaart en digitaliseren die zorgen voor veilige (transport) bewegingen in een steeds complexer wordende infrastructuur evenals het ontwikkelen van de grootste en meest duurzame haven die zee en land verbindt.

Op het gebied van energietransitie ziet men schonere scheepvaart (alternatieve brandstoffen) en eilanden op zee voor windparken onderhoud en omzetten elektriciteit in waterstof. Vragen bestaan met betrekking tot afname olie- en/of gaswinning en afgedankte offshore bouwwerken. Men verwacht een toenamen in de pleziervaart door toename levensverwachting, vergrijzing en trend naar 'vakantie in eigen land'. Dit biedt kansen voor groei in toerisme, recreatie-/cruisehavens en watersport.

Multifunctioneel gebruik van de Noordzee leidt tot meer/aangescherpte regelgeving en ook bestaat de IMO 2050 ambitie voor halvering $\mathrm{CO}_{2}$ ten opzichte van 2008. Kansen worden gezien in meer/aangescherpte regelgeving die bij voorkeur uit Europa komt (concurrentiepositie) en met groene haven als trekker.

Hoewel de Brexit-deal ervoor zorgt dat handel tussen de EU en het UK grotendeels zonder invoerrechten kan plaatsvinden, geldt de vrijstelling niet voor goederen die niet aan de voorgeschreven oorsprongsregels voldoen. Hiermee zal de Brexit-deal leiden tot een lichte afname in handel tussen de UK en de EU. Daarnaast is de verwachting dat de Brexit-deal zal leiden tot een transitie naar duurzame visserij in windparken. Kansen worden gezien in verplaatsing van activiteiten en maritieme dienstverlening van de UK naar Rotterdam en ontwikkeling nieuwe diensten als poort voor Europa.

Wat betreft ruimte en uitbreidingsmogelijkheden verwacht men toename in woon- en werkfuncties evenals behoefte aan havencapaciteit (met name kade-gebonden functies) - dit wel sterk afhankelijk van groei wereldhandel en post-coronaontwikkelingen. Kansen worden gezien in hergebruik van vrijkomende (raffinaderijen) en hergebruik (verouderde) terreinen, tanken/bunkeren op zee, samenwerking met andere (Nederlandse) havens en hoogwaardige maritieme dienstverlening (handel, juridisch, verzekering). 
Tot slot verwacht men een groei in ontwikkeling en onderhoud offshore installaties (windparken) en decomisionering olie- en gasinstallaties. Kansen die hieruit voorvloeien zijn werkgelegenheid (werkschepen en onderhoud windparken) en kennisontwikkeling (zero-emissie bouw/onderhoud windparken en laad/tankstations).

\section{B3.4 Energie}

Op het gebied van Energie verwacht men met betrekking tot windenergie-op-zee meer windparken voor de kust van Zuid-Holland, een toename in de afhankelijkheid van windenergie-op-zee voor energievoorziening en een toename in elektriciteit aanbod dat niet synchroon loopt met vraag. Kansen worden gezien in versnelling windenergie-op-zee ( $2 \mathrm{GW} /$ jaar; actueel door KEV en Klimaat Akkoord), voor toeleveranciers (bouw, inspectie en onderhoud), energieopslag (waterstof; Delta21.nl) en medegebruik windparken (solar energy; golfenergie). Ook mogelijkheden voor sturen op meer flexibiliteit in elektra tarieven binnen de voorgestelde wet elektriciteit.

Met betrekking tot productie en gebruik fossiele brandstoffen verwacht men een afname in olie- en gaswinning op zee en dat grote energiebedrijven hierop inspelen. Kansen zijn er voor bio-based energie (gebruik makend van kennis Rotterdam) en schonere lucht. Parallel aan deze afname in olieen gaswinning staat $\mathrm{CO}_{2}$-opslag die, als kans, zou kunnen plaatsvinden gebruikmakend van bestaande olie- en gasinfrastructuur.

Men verwacht een verandering in energievraag naar groene energie, aandacht voor kernenergie, electrificatie en een algemene toename in vraag. Kansen zijn er voor lagere afhankelijkheid externe energie, het ontwikkelen van een nieuwe energiesector en verbeterde energie-efficiënte (bijvoorbeeld via $\mathrm{CO}_{2}$-heffing) - daarbij gebruik makend van de aanwezige kennis in Zuid-Holland.

Om elektriciteit op te slaan kunnen waterstof (na 2030) en getijdenenergie (valmeer; visie) een belangrijke rol krijgen als energiedrager. Kansen bestaan voor ontwikkelen waterstofindustrie en getijdenenergie.

Van de energietransitie verwacht men een nadrukkelijke rol van de Noordzee (windenergie-op-zee; solarenergie; golfenergie; getijdenenergie) en een algemene elektrificatie (eerst mobiliteitssector, daarna residentieel, industrie en landbouw). Kansen bestaan om deze transitie te omarmen en, waar nodig, te ondersteunen met onderzoek.

\section{B3.5 Voedsel}

Op het gebied van Voedsel heeft men met betrekking tot de toename in verzilting door zeespiegelstijging vooral zorgen over de kostbare zoute aquacultuur op land, de teelt van zout minnende zoetwater gewassen nog niet rendabel is en de verzilting die bodemdaling vergroot. Er wordt ook gezegd dat de landbouw zijn concurrentie positie ten opzichte van buitenland verliest. Er wordt wel een vraag gesteld of de verzilting niet tegengegaan wordt door doorspoeling met schoon water. Voor kansen kijkt men naar de ontwikkeling van nieuwe groenten-soorten, voor zaadveredelaars en marketing van kwaliteitsproducten uit de 'Zilte Delta'. Er wordt ook gezegd dat zoetwater aanvoer naar het westen vergroot en vastgehouden kan worden.

In verband met de Toename verzuring en temperatuur zeewater door klimaatverandering is er nog veel onbekend en veel onderzoek is nodig. Uiteindelijk staat en valt alles met rendement van een activiteit, en daar speelt ook de concurrentie in de EU een rol, zoals voor schelpen. Kansen ziet men voor toerisme, en ook wel voor korte ketens. Maar hoe staat het met nieuwe flora en fauna? Elke verandering biedt weer kansen, maar kennisontwikkeling en innovatie zijn nodig. Het afremmen van deze ontwikkelingen is voor provincie niet te doen.

De trend in Selectieve vangsttechnieken ziet men in meer kleinschalige visserij in windparken. Kansen volgen daaruit voor bedrijven in Zuid Holland die te maken heeft met ontwikkeling en verkoop van 
visserij technieken, en gekoppeld aan meer kansen voor korte ketens: producten uit Noordzee verkopen in lokale retail en restaurants.

Afname visserijgebieden kan gevolgen krijgen voor de volume vis en een consolidatie van de visserijvloot. De zorg is dat de omvang van de zeevisserij vloot erg klein wordt, wellicht te klein om voort te bestaan, met verlies banen op zee en wal. Zorgelijk is ook dat de zee in de zomer te warm wordt maar niet warm genoeg voor soorten uit het zuiden. Kansen worden vooral gezocht in een nieuwe branding: Noordzee vis. Ook drijvende visfarms is een kans. Tegelijkertijd vraagt dit om alternatieven voor (jonge) vissers, of omscholing.

Toename van zeewierteelt leidt tot meer onderzoek naar diverse soorten wier, naar meer focus op de hele 'voedsel web' en de links tussen meerdere ketens en nieuwe oogst technieken. Er is ook een trend naar ontwikkeling van offshore zeewierteelt. Naast ruimtelijke beheer dient nu zich ook nutriënten- beheer aan. Zeewier biedt gezond en duurzaam voedsel, en oplossingen voor klimaatbeleid (carbon sequestration en beperking van de methaan uitstoot van melkvee. Zuid-Holland kan zich profileren door kansen te bieden voor meer samenwerking in de teken, de teelt, de verwerkende industrie, nieuwe oogst technieken, als leverancier van technologie, als DE locatie om verder te bouwen aan de eerste volwaardige farm op zee.

Veruit de meeste aandacht kreeg het thema Veranderende consumptiepatronen. Steeds meer mensen worden zich bewust van gezondheid, dieet, milieu, biodiversiteit en klimaat. De bewustwording van het nut van zeewier bij deze zaken is nu gaande. Er is echter twijfel of mensen in Nederland extra geld over hebben voor een beter product. Hierin zullen supermarkten hun verantwoordelijkheid moeten nemen, met aandacht voor meer zeewier en zeewier gerelateerde gerechten. De provincie kan hier mooi op inspelen: voor meer aandacht voor korte ketens, het beïnvloeden van groepen als de jeugd/schoolkinderen, inspelend op social media en TV. In de praktijk is dit een heel traag proces. Samenwerking met retail en gemeenten worden genoemd als kans. Er zijn wel zorgen over het ruimte in het schap voor zeewier en in een breder context de macht van de retail in de keten. De vraag is wat de rol is van de provincie in de maricultuur? RO op zee wordt grotendeels bepaald door windparken. Het is een enorme opgave om de discussie aan te gaan zodat we de zee ook kunnen gaan gebruiken voor voedselproductie. En, de provincie zit niet aan tafel bij het Noordzee overleg. Er zijn wel kansen om de focus te richten op minder bulk en meer kwaliteit, maar de verwerkende industrie en retail zit er niet echt op te wachten. De provincie kan toch aan de slag gaan met ondernemers. 
Wageningen Economic Research Postbus 29703

2502 LS Den Haag

T 0703358330

Ecommunications.ssg@wur.nl

www.wur.nl/economic-research

Wageningen Economic Research RAPPORT

2021-088
De missie van Wageningen University \& Research is 'To explore the potential of nature to improve the quality of life'. Binnen Wageningen University \& Research bundelen Wageningen University en gespecialiseerde onderzoeksinstituten van Stichting Wageningen Research hun krachten om bij te dragen aan de oplossing van belangrijke vragen in het domein van gezonde voeding en leefomgeving. Met ongeveer 30 vestigingen, 6.800 medewerkers (6.000 fte) en 12.900 studenten behoort Wageningen University \& Research wereldwijd tot de aansprekende kennisinstellingen binnen haar domein. De integrale benadering van de vraagstukken en de samenwerking tussen verschillende disciplines vormen het hart van de unieke Wageningen aanpak. 



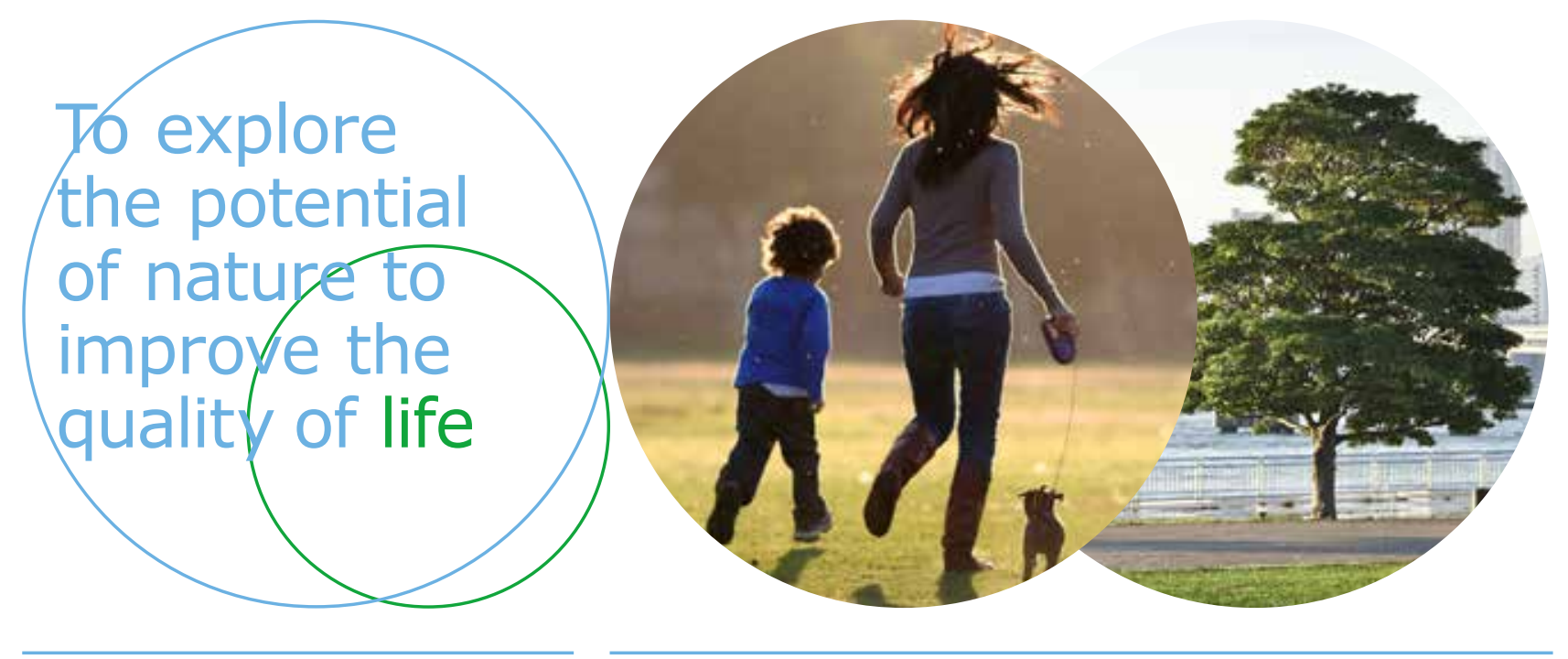

Wageningen Economic Research Postbus 29703

2502 LS Den Haag

T 0703358330

E communications.ssg@wur.nl www.wur.nl/economic-research

Rapport 2021-088

ISBN 978-94-6395-895-0
De missie van Wageningen University \& Research is 'To explore the potential of nature to improve the quality of life'. Binnen Wageningen University \& Research bundelen Wageningen University en gespecialiseerde onderzoeksinstituten van Stichting Wageningen Research hun krachten om bij te dragen aan de oplossing van belangrijke vragen in het domein van gezonde voeding en leefomgeving. Met ongeveer 30 vestigingen, 6.800 medewerkers ( $6.000 \mathrm{fte}$ ) en 12.900 studenten behoort Wageningen University \& Research wereldwijd tot de aansprekende kennisinstellingen binnen haar domein. De integrale benadering van de vraagstukken en de samenwerking tussen verschillende disciplines vormen het hart van de unieke Wageningen aanpak. 